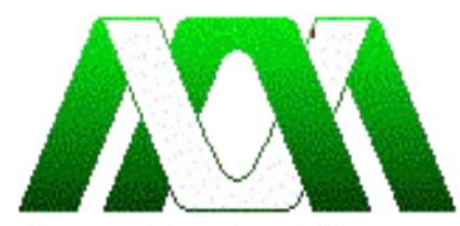

Casa abierta al tiempo

UNIVERSIDAD AUTÓNOMA METROPOLITANA

UNIDAD IZTAPALAPA

DIVISIÓN DE CIENCIAS SOCIALES Y HUMANIDADES

POSGRADO EN CIENCIAS ANTROPOLÓGICAS

\title{
MASCULINIDAD Y FIESTA EN EL TEPETLAOXTOC \\ DEL ACOLHUACÁN SEPTENTRIONAL. \\ ESPACIOS DE VIRILIDAD AL INTERIOR DE UN MUNICIPIO DEL ESTADO DE MÉXICO.
}

Roberto Rivera Pérez

Tesina de Maestría en Ciencias Antropológicas

Director: Dr. Scott Robinson Studebaker

Asesores: Dr. Carlos Garma Navarro

Dr. Alejandro Cerda García

México, D.F.

Agosto, 2009 
Introducción

Objetivos

Marco teórico

Posturas teóricas del espacio

mexicano

Los espacios públicos y privados en los pueblos mexicanos

Los espacios temporales en las fiestas de los pueblos mexicanos

$2.0 \quad$ Las fiestas patronales en el pueblo de Tepetlaoxtoc, Tepetlaoxtoc de Hidalgo 


\section{Índice de Anexos}

Anexo 1: Mapa de las principales

calles del centro de Tepetlaoxtoc

Anexo 2: Sinopsis del arribo de los

frailes Dominicos a la Nueva

España.

Anexo 3: Breve historia del ruedo en

América.

Anexo 4: Permisos para la pelea de

gallos.

Anexo 5: Incidentes en el simulacro

de la mayordomía de los arrieros.

Bibliografía

\section{Índice de Narcocorridos} mexicanos

Grupo

Exterminador

"El toro grande"

"Clave privada"

"La peda"

Página

65

73

Originales

Fotografía

\section{Índice de fotografías}

1
2
3
4
$5-6$
7
8

La Calle de la Cruz

Calle Tlacaluca

28

Calle Ocoyococ

28

Serenata San Sebastián $\quad 46$

El baile de los vaqueros $\quad 48$

Cuadrilla de sembradoras 53

El patrón, las contadoras y el 53

capataz

$9 \quad$ Cuadrilla de los sembradores 56

10 Los infantes de la cuadrilla de los 56

sembradores

11 La semilla de los sembradores para 56

el voleo

12 Jaripeo en honor a San Sebastián en el barrio del Calvario, Tepetlaoxtoc centro

13-14 La arena del palenque 69

15 Comprobando el peso de los gallos 70

16 Cinturón charro con detalles 73

bordados de gallos en combate

$17 \quad$ Castillo de fuegos pirotécnicos 77

18 Maguey para raspar en una esquina 81

de la calle Caxcantla en la orilla del

centro de Tepetlaoxtoc

19 Calle Tlacaluca durante el día de los 83

tlachiqueros

20 Los tinacos en camioneta y el

Tinacal temporal en la Calle de la

Cruz 
21-22 Algunos participantes en la

mayordomía de los arrieros

23-24 Miembros de la comparsa de los 93

$\begin{array}{lll} & \text { Serranos } & \\ 25 & \text { Serrano cargando a su hijo } & 95 \\ 26 & \text { Bandidos huyendo en dirección a "la } & 96\end{array}$

26 Bandidos huyendo en dirección a "la

$27 \quad$ Las tlacualeras 96

28 Bandido huyendo con una 96

29 María Cristina 104 


\section{INTRODUCCIÓN.}

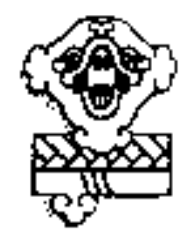

Tepetlaoxtoc: "En las cuevas de tepetate"

El espacio al ser un constructo social de carácter universal, se convierte en el reflejo de la identidad de los grupos que lo transitan; éstos marcan sus límites territoriales sobre la base de simbolizaciones, imágenes, creencias (religión), leyendas y mitos. Gracias a ese orden social, se puede identificar: "en dónde se ubica lo sagrado y lo profano", "dónde se puede transitar con seguridad y en dónde se tiene que ir con cuidado", "dónde inicia una comunidad y finaliza otra", "dónde es el ámbito público y el privado". Son pautas que interactúan entre sí y exigen en cada situación una forma de comportamiento específico de sus ocupantes por el rol de género y el prestigio social que se debe mantener y acrecentar, porque "todo orden social es, a la vez, un orden sexual". En ese sentido, se tiene que tomar en consideración, que mientras más pequeño sea un poblado, más difícil será que existan individuos con carácter de anónimos frente a sus vecinos y viceversa: es decir, son vecinos anónimos ante las demás personas. Argumento que se puede confirmar en un dicho popular mesoamericano: "Pueblo chico, infierno grande", pero en el caso de los actuales pueblos mesoamericanos, y tomando en consideración el actual aumento de población, el número de personas que emigran de otros estados hacia las comunidades u oriundos que migran hacia otros países, se puede parafrasear del siguiente modo: "pueblo grande, infierno extremo", pues a pesar de los grandes avances tecnológicos y la incorporación de las comunidades mesoamericanas a los procesos de globalización; en los pueblos continúa existiendo un fuerte peso social creado en los vínculos de parentesco por filiación, alianza y compadrazgo. En este contexto, se enfatiza en la alianza y / o el parentesco ritual (compadrazgo), como una forma de rito de paso de integración para las familias o personas emigrantes que arriban a la comunidad. También, se utiliza a manera de relacionarse con los vecinos de otras comunidades, principalmente si se comparten los mismos intereses, cosmología y/o trabajos. Cabe aclarar, que estos tipos de relaciones de parentesco pueden ocurrir hasta una o dos generaciones después de la residencia definitiva en el pueblo.

Fue a finales del mes de enero del año 2009, cuando tuve la oportunidad de observar directamente las diez mayordomías en honor a San Sebastián Mártir, como son: Ios mexicanos, la del 19 de enero, la fiesta grande (20 de enero), los cirios, las molenderas, los gañanes, 
tlachiqueros, comerciantes, albañiles y los arrieros. Así como los simulacros, representaciones, danzas regionales y bailes que se realizan ya sea en honor a San Sebastián Mártir o durante sus festividades en el pueblo de Tepetlaoxtoc de Magdalena ${ }^{1}$ del municipio de Tepetlaoxtoc de Hidalgo en el Estado de México. A pesar de realizar una investigación sobre las mayordomías tepetlaoxtoqueñas, en ningún momento centro mi atención en su función política, su historia o su desenlace, pues la investigación se limitó a observar e interpretar los espacios propios de la demostración de la virilidad masculina que se manifestaban durante estas festividades. En ese sentido, el presente ensayo consta de tres capítulos básicos:

El primero alude a los objetivos generales de la investigación, se profundiza en algunos aspectos de las preguntas que guiaron la investigación. De la misma forma, se presenta el marco teórico y las primeras hipótesis que en conjunto acompañaron al trabajo de campo.

El segundo capítulo, discute la historia del arribo de la imagen de San Sebastián y finalmente la compara con la identidad de los tepetlaoxtoqueños. De la misma forma, en este capítulo se describen e interpretan las relaciones de dominación masculina a cada una de las mayordomías, las danzas (las sembradoras, dancitas, los sembradores, vaqueros y serranos). También se analizan algunos de los juegos propios para la demostración de la virilidad, como son: jaripeos, demostraciones ecuestres, palenques y representaciones históricas; así como la representación simbólica de algunos de esos casos. Y a manera de complementar la relación de dominio y poder masculino, se presentan tres casos de resistencia femenina que se hace evidente durante estos días de fiesta.

El tercer capítulo introduce a la temática del parentesco, mencionando algunos tipos de parentesco ritual que se lograron recabar durante la investigación. El motivo de incorporar esta tipología es dejar entre abierta la puerta del parentesco. Temática que se tendrá que profundizar en la siguiente etapa de esta investigación.

Palabras claves para la primera parte:

Masculinidad², fiesta ${ }^{3}$, espacio $^{4}$, virilidad 5 , Tepetlaoxtoc, Acolhuacán Septentrional

\footnotetext{
${ }^{1}$ A partir de este momento lo referiré como Tepetlaoxtoc centro o simplemente Tepetlaoxtoc.

2 “...la masculinidad, per se, es un constructor social, que cada sociedad moderna a través del tiempo y la historia, mediante sus costumbres, tradiciones, condiciones socioeconómicas y políticas, símbolos, valores, expectativas, formas de pensar y sentir. Que lógicamente son diferentes para cada grupo social, e incluso difiere para una misma sociedad en momentos diferentes de su historia” (Tolalpa; 2005:181). Al respecto, “...la masculinidad implica ...varias historias a la vez. Se trata de la búsqueda del hombre individual para acumular aquellos símbolos culturales que denotan virilidad, señales de que él lo ha logrado (ser hombre). Se trata de esas normas que son usadas contra las mujeres para impedir su inclusión en la vida pública y su confinamiento a la devaluada esfera privada. Se trata del acceso diferenciado que distintos tipos de hombres tienen a esos recursos culturales que confieren la virilidad y de cómo cada uno de estos grupos desarrolla entonces sus propias modificaciones para preservar y
} 


\subsection{OBJETIVO}

Partiendo del supuesto, que las festividades propias de las mayordomías continúan siendo espacios de interacción en los pueblos que fomentan las alianzas matrimoniales, el circuito de actores sociales en búsqueda de cónyuges y diversos tipos de intercambios entre los grupos. Y también son consideradas como $\operatorname{arenas}^{6}$ en las cuales se continua disputando el prestigio social (capital social7), el poder político y la dominación masculina -como lo sugiere Mendoza (2004) y Ochoa (2008). Nos proponemos investigar: La manera en que se transforman los espacios públicos en distintos escenarios y arenas, durante los tiempos festivos. Donde la participación de los hombres que son representantes de su masculinidad hegemónica ${ }^{8}$, denotará la forma en que se establece y demuestra frente a todas las mujeres y los varones visitantes, lo que significa ser un hombre en el Tepetlaoxtoc del Acolhuacán Septentrional. Tomando en consideración: que el hecho de realizar una demostración propia de la masculinidad, podría implicar una acumulación o pérdida de distintos capitales, posiblemente la apropiación del cuerpo de las

reclamar su virilidad. Se trata del propio poder de estas definiciones, que sirven para mantener el poder efectivo que los hombres tienen sobre las mujeres y que algunos hombres tienen sobre otros hombres" (Kimmel; 1997: 50-51) -Cursivas mías-.

${ }^{3}$ Como definición de fiesta, retomo: "Sono in molti ad observare che se il tempo liberato dal lavoro potrebbe essere un periodo ideale per ritrovarsi, per "divertirsi” in senso propio, per rigenerarsi, per confrontarsi con gli altri, in genere, si trasforma in vacanza, in un cedimento al turismo di massa” (Nesti; 2007: 3). (En muchas ocasiones he observado que es el tiempo libre del trabajo, puede ser un periodo ideal para encontrar personas, para "divertirse” en sentido propio, para regenerarse, para encontrarse con la alteridad, en general, se transforma en vacaciones, en una entrada al turismo de masas).

${ }^{4}$ Entendido como: "El espacio de caracteres fijos es uno de los modos fundamentales de organizar las actividades de los individuos y los grupos. Comprende manifestaciones materiales tanto como normas ocultas, interiorizadas, que rigen el comportamiento cuando el hombre se mueve sobre la tierra. ...La gente vive "en pleno relajo" o "en estado constante de confusión” es la que no logra clasificar las actividades y las cosas según un plan espacial uniforme, consecuente o previsible. En el otro extremo de la escala está la cadena del montaje, una organización precisa de objetos en tiempo y espacio“ (Hall; 1972: 127-128).

5 “La virilidad, entendida como capacidad reproductora, sexual y social, pero también como aptitud para el combate y para el ejercicio de la violencia” (Bourdieu; 2000: 68).

${ }^{6}$ Turner que esta citado por Varela (2005), la define como: "Una arena es un marco -institucionalizado o no- que manifiesta funciones como un escenario para una interacción antagónica dirigida a llegar a una decisión públicamente reconocida” (Varela; 2005: 102-103).

7 Bourdieu (1991), lo define de la siguiente manera: “...el efecto que produce la imposición de titulaciones, caso particular del efecto de asignación de estatus, positivo (ennoblecimiento) o negativo (estigmatización), que todo grupo produce al asignar a los individuos a unas clases jerarquizadas” (Bourdieu; 1991: 20).

${ }^{8}$ Cito de Connel: "La masculinidad hegemónica no es un tipo de carácter fijo, el mismo siempre y en todas partes. Es, más bien, la masculinidad que ocupa la posición hegemónica en un modelo dado de relaciones de género, una posición siempre disputable ...La masculinidad hegemónica se puede definir como la configuración de práctica genérica que encarna la respuesta corrientemente aceptada al problema de la legitimidad del patriarcado, la que garantiza (o se toma para garantizar) la posición dominante de los hombres y la subordinación de las mujeres” (Connel; 1997: 41-42). Y al ser explicada por Kimmel, le otorga un nuevo significado: Es “...la imagen de la masculinidad ...destinada a enseñar a los hombres jóvenes cómo llegar a ser “verdaderos hombres” (Connel 1987). La definición hegemónica de la virilidad es un hombre en el poder, un hombre con poder, y un hombre de poder” (Kimmel; 1997: 50). -La investigación optó por emplear esta última-. 
mujeres y / o probables intercambios y alianzas con otros grupos. Para cubrir el objetivo de este ensayo, más adelante se presentarán algunos de los cuestionamientos que acompañaron esta investigación.

El municipio de Santa María Magdalena de Tepetlaoxtoc está conformado por siete pueblos de origen colonial, y el pueblo de Tulteca Teopan que se remonta a un origen prehispánico (tomando en cuenta que muy probablemente su ubicación contemporánea no coincida con el asentamiento original). Los pueblos se pueden entender como:

“...espacios físicos territoriales y simbólicos que remiten a un pasado remoto con un origen prehispánico o colonial que pueden estar sustentado sobre la base de evidencias documentales, como son: códices, mapas, cartas o nombramientos coloniales, y reforzado por la historia oral (fundación mítica, leyendas de los santos patrones, mitos populares, etc.), monografías locales, la traza colonial, zonas arqueológicas, evidencias prehispánicas o hechos duros temporalizados, es decir, edificios con fechas de su construcción o modificación. Y utilizando puntos de referencia como son montañas, cerros, cuevas o ríos, como una manera de presentar los espacios territoriales que forman parte de su cosmovisión.

... Además, los oriundos se asumen como descendientes simbólicos del santo patrón de su pueblo, mismo que los procura de sus necesidades y los protege frente a las adversidades externas a su territorio. Por último, el conjunto de esos elementos son utilizados como referentes de la identidad colectiva generando un habitus, que hace partícipe a todos los oriundos sobre la base de los "usos y costumbres", a manera de excluir a los avecindados y de servir como elemento diferencial frente a las poblaciones circunvecinas con las que se puede compartir algún tipo de reciprocidad, ya sea: ceremonial, rituálica, económica o matrimonial" (Rivera; 2008: 5-6).

Hay que considerar que no todos los pueblos tienen barrios a su interior, con excepción de las comunidades de Jolalpan y Tepetlaoxtoc (cabecera municipal). Y que todos ellos se encuentran inmersos en el proceso de globalización mundial, a pesar de su reciente incorporación a la modernidad precedida por la entrada del transporte público a partir del año 2000.

Los habitantes del municipio cuentan con la protección celestial de dos santos patrones "principales" o "totémicos": a) Santa María Magdalena y b) San Sebastián Mártir. Son estos santos a los que se les venera y cuyas solemnidades se ubican por encima de las fiestas satelitales que se desarrollan en honor a los demás santos patrones tanto de los barrios, como de los pueblos del municipio. En consecuencia: ¿Cuál festejo es más importante para los habitantes del municipio?, Tomando en cuenta que "...todo orden social es, a la vez, un orden sexual" (Godelier; 1997: 24), ¿Será posible que el festejo de San Sebastián Mártir pueda ser más ostentoso que el realizado en honor a su homónima, quizá por la diferencia sexual y por otros motivos poco evidentes? Y ¿En base de la historia nómada propia de los chichimecas de esta región -como lo comentaron Pérez Lizaur (1975) y Valle (1993)-, existirá en la actualidad 
una relación con el imaginario colectivo de la población, su historia y las características del arribo de San Sebastián Mártir a Tepetlaoxtoc?

Durante las fiestas patronales del municipio o satelitales de los barrios y pueblos, se realizan eventos ocasionales que surgen con motivo a la adoración de cada santo patrón, como son: bailes, jaripeos, rodeos, palenques y carreras de caballos. Circunstancia que permite cuestionar: ¿Esos espacios de interacción son propicios para la circulación de agentes o el intercambio matrimonial?, ¿De qué manera podrían ser definidos el charro y el vaquero mexicano que residen en este municipio?, ¿Qué influencia han tenido los medios masivos de comunicación, las películas del cine de oro mexicano y las industrias culturales en relación con esas imágenes identitarias?, ¿Qué símbolos caracterizan a los vaqueros tepetlaoxtoqueños?, ¿La práctica estará extendida en todos los pueblos del municipio o solamente a ciertas comunidades?, ¿Los palenques, jaripeos y rodeos podrían ser utilizados como espacios de demostración simbólica de virilidad masculina frente a otros varones y ante las mujeres espectadoras -como lo podría sugerir Geertz (1987)?, ¿Será pertinente la propuesta de Geertz (1987) sobre la pelea de gallos en el territorio mesoamericano?, ¿Se pueden considerar a los palenques y jaripeos como arenas políticas y simbólicas?, ¿Qué imagen proyectaría alguna mujer que participe activamente en un palenque, rodeo o en un jaripeo realizando actividades propias del ámbito masculino, incluyendo la acción de derramar voluntaria y simbólicamente su propia sangre? Recordemos que la participación de las mujeres en actividades propias o exclusivas de los hombres tienden a denigrar al evento, como lo sugieren Pierre Bourdieu (2000) y Francoise Héritier (2007). Por esos eventos ocasionales: ¿Estos, podrán ser un espacio de preámbulo para relaciones sexuales ocasionales, o mejor dicho para que existan autodonaciones sexuales y/o relaciones sexuales extramaritales con motivo de la demostración viril, el capital social y/o económico que ha sido obtenido por el vaquero gracias a las victorias en los gallos, durante la carrera de caballos o en menor medida montando un toro?.

\subsection{MARCO TEÓRICO.}

Con la finalidad de presentar los resultados del trabajo de campo exploratorio que se realizó durante el mes de enero del año 2009 en el municipio de Tepetlaoxtoc en el Estado de México, he decidido retomar la noción de la estructura levistraussiana y su operador lógico que abajo cito como elementos que permitirán mostrar y explicar: el ciclo festivo propio a San Sebastián Mártir, las características de los espacios propios para la demostración de la virilidad masculina, los espacios de la complementariedad y / o resistencia femenina y una aproximación a la relación que mantiene con el parentesco ritual. 
"El principio fundamental afirma que la noción de estructura social no se refiere a la realidad empírica, sino a los modelos construidos de acuerdo con ésta. Aparece, así, la diferencia entre dos nociones tan próximas que a menudo se las ha confundido; quiero decir, las de estructura social y de relaciones sociales. Las relaciones sociales son la materia prima empleada para la construcción de los modelos que ponen de manifiesto la estructura social misma. 9 Esta no puede ser reducida, en ningún caso, al conjunto de relaciones sociales observables en una sociedad determinada. Las investigaciones de estructura no reivindican para sí un campo propio entre los hechos sociales; constituyen más bien un método susceptible de ser aplicado a diversos problemas etnológicos, y se asemejan a las formas de análisis estructural empleadas en diferentes dominios." (Lévi-Strauss; 1987: 301).

Así aparecen los siguientes pares de oposiciones que son el resultado de las relaciones sociales y la realidad empírica que fue observada durante los festejos de San Sebastián Mártir en la cabecera del municipio de Tepetlaoxtoc:

arriba / abajo, masculino / femenino, hombre / mujer, joven / anciano, santo / profano, permitido / prohibido, voluntario / involuntario, lugar / no lugar, verdadero I falso, primero / último, oriundo / fuereño, superior / inferior.

Son dicotomías presentes en el inconsciente de cada uno de los participantes que estuvieron interviniendo directa (entregando ofrendas, danzas, realizando representaciones propias de su mayordomía) o indirectamente (observadores y transeúntes) durante los festejos de su santo patrón. Son elementos estructurales utilizados en este ensayo como se podrá ver más adelante. Primero ahondaré en los siguientes pares de oposición:

masculino / femenino, hombre / mujer, superior / inferior

La masculinidad... ¿Un tema propio de los estudios del parentesco?

Las primeras etnografías que se desarrollaron en el ámbito mundial; es decir, aquellos trabajos que fueron posteriormente conocidos como la "antropología clásica", buscaron explicar el comportamiento de aquellas personas que la corona británica había hecho honorablemente sus vasallos en el continente africano y asiático, pero para poder gobernarlos adecuadamente y evitar en lo posible levantamientos y sublevaciones, fue necesario conocer: cómo piensan, qué creencias religiosas tienen, de qué manera están organizados filialmente, cómo eligen a sus

\footnotetext{
${ }^{9}$ Subrayado mío.
} 
autoridades, cómo funciona su sistema político, etc. Lo que provocó que las primeras etnografías adolecieran de una pregunta básica: ¿Y dónde están las mujeres de este tiempo?

"Debería ser obvio que las omisiones y tergiversaciones androcéntricas de la antropología clásica no se debían exclusivamente al hecho de que los antropólogos en su gran mayoría fuesen hombres. A fin de cuentas, como se ha demostrado desde la propia antropología de género, «la biología no es destino» sino que las diferencias sexuales son siempre elaboradas simbólicamente, de manera que concepciones acerca de lo que es ser «hombre» y «mujer» en una cultura están cargadas de significados que trascienden los puros «hechos» de la biología humana. Sin embargo, ese «sentido común» sobre lo que es pertinente a «hombres» y a «mujeres», por incidir de modo decisivo en la percepción del orden en el mundo en general, ejercía una influencia importante más allá de la etnografía que se escribía plasmándose también en la escala de valor según la cual se decidían y medían la relevancia y el mérito académico relativo de temas y enfoques de investigación" (Stolcke; 1996: 336) ${ }^{10}$

Stolcke (1996) identifica algunos trabajos etnográficos que fueron elaborado por mujeres y no alcanzaron el reconocimiento por su investigación, tal es el caso de:

"...la obra de Margaret Mead conquistó muy pronto amplia fama en su propia época, posiblemente gracias a lo transgresor de su tema, la sexualidad, y a su combativa e irreverente vitalidad y personalidad imponente. Las monografías de Audrey I. Richards y Phillis M. Kaberry, en cambio, que por primera vez enfocaban en especial las múltiples identidades, los poderes y las diversas definiciones sociales de mujeres en distintas culturas, producto de prolongadas, intrépidas y minuciosas investigaciones de campo, quedaron por lo general relegadas a un segundo plano en un contexto académico en el que, a lo sumo se las veía como «asunto de mujeres». Aunque hubo antropólogas que durante el apogeo de la antropología estructural-funcionalista escribían sobre el mundo de las mujeres ....sus aportaciones caían en saco roto" (Stolcke; 1996: 337)

Pero al replantear la premisa original (¿Y en dónde están las mujeres de este tiempo?), la respuesta sería:

"En las teorías de parentesco y de matrimonio resultaba, por supuesto, imposible incluso para los antropólogos dejar de lado a las mujeres, pero ellas aparecían en sus etnografías invariablemente como hijas, hermanas o esposas de uno o incluso varios hombres, como meros objetos de intercambio de sus capacidades reproductivas entre hombres. Esta mirada androcéntrica la compartía la gran mayoría de la profesión por lo menos hasta los años ochenta" (Stolcke; 1996: 335)

Y fue hasta estos años (los ochentas), que comenzaron a proliferar las investigaciones sobre la relación entre los géneros y las consecuencias sociales que provocó la aparición de la píldora anticonceptiva en la década de los 70's; la cual, permitió entre otras cosas: la liberación sexual, es decir, la posibilidad de que las mujeres hicieran uso de su cuerpo y gozaran de su sexualidad sin correr el riesgo de un embarazo no deseado e iniciar un serio cuestionamiento sobre la

\footnotetext{
${ }^{10}$ Subrayado mío.
} 
manera en que está dividido y organizado el mundo, como lo comenta Granados (2002) y Díaz Diego (2006):

"La cosmovisión de un mundo dividido entre lo masculino y lo femenino tiene su expresión, en el individuo, en la postura consciente o inconsciente que asumen los sujetos a través de comportamientos concretos cuyos contenidos están estructurados por códigos simbólicos que norman o reglamentan la vida personal y las relaciones que establecen con los "otros" (Basaglia, 1987) (Lagarde, 1990) (Lamas, 2000)" (Granados; 2002: 86).

"Los géneros son constructos culturales que viene a corporeizar agregados recurrentes de las acciones y disposiciones materiales y simbólicas, físicas y mentales que dotan de sentido figurativo al ser sociosexual. Las construcciones de género trascienden la bipolaridad cromosómica para revestir de significado social, dentro de las diferentes lógicas estructurales de pensamiento, a cada uno de los individuos miembros del universo cultural, ingresando en una partición establecida y formalmente definida del mundo que en adelante les conferirá, en virtud de su adscripción de género, unos derechos y obligaciones que marcarán todos los ámbitos de sus vidas, desde los más sociales como status, roles familiares, papel dentro de los rituales u oportunidades de empleo hasta las disposiciones más apriorísticamente individuales como los gustos, las inquietudes, las actitudes, el orden de los valores, el carácter ...pasando por las características de nutrición, la situación jurídico-legal, la asunción y el posicionamiento ante distintas problemáticas, las lógicas proxémicas, las disposiciones corporales, gesticulares, de voz, incluso llegando a condicionar el uso del lenguaje"

(Díaz Diego; 2006: 157-158).

Actualmente, el debate antropológico sobre el parentesco ha comenzado a abandonar rápidamente las investigaciones sobre las reglas de filiación, alianza y residencia. No por ser temáticas obsoletas, sino porque como lo ha mencionado Olavarría:

"...tal percepción diferencial responde efectivamente a un cambio en la ubicación misma del parentesco en el seno de lo social." (Olavarría; 2008: 236)

Situación que encuentra su razón de ser al presentarse frente a los diversos procesos de globalización que están manifestados en la creciente flexibilidad de los procesos económicos, la mayor dispersión geográfica de los distintos eslabones de producción, la migración internacional, las redes de subcontratación y sociedades de firmas. Así como en las nuevas tecnologías de reproducción, legislaciones sobre la adopción internacional, el matrimonio homosexual, nuevas construcciones del género masculino (la metrosexualidad11) y la explotación laboral infantil y femenil. Sin olvidar la fuerte declinación del modelo patriarcal que se caracteriza por la

\footnotetext{
11 "El típico metrosexual es un joven con dinero para gastar, que vive en la ciudad, donde están las mejores tiendas, clubs, gimnasios y las mejores peluquerías. Puede ser oficialmente gay, hetero o bisexual, pero esto no tiene tanta importancia porque se ve así mismo como su propio objeto de deseo y placer. De profesiones liberales como modelos, medios de comunicación y productoras o músicos pop y, ahora, también deportistas, saben que atraen, aunque la verdad sea dicha, lo mejoran con productos cosméticos masculinos” (Díaz Diego; 2006: 160).
} 
autoridad que ejerce el padre sobre la esposa y sus hijos en los senos de las familias tradicionales y conservadoras.

Todo este contexto globalizado ha incitado a algunos estudiosos de la teoría del parentesco a realizar investigaciones en los campos del género, la reproducción, sexualidad y las relaciones de poder entre los agentes.

Al respecto, la correspondencia que se forma entre el parentesco y las relaciones de poder y / 0 las diferencias del status entre los sexos, se puede evidenciar en el concepto de la doble metamorfosis propuesta por Godelier (1997):

"A través de las relaciones de parentesco, que son las relaciones personales y entre generaciones que pasan de individuo a individuo y de generación a generación, se transmiten riquezas, recursos que son, a su vez, las condiciones materiales y sociales de su existencia. En general, en todas las sociedades, a través del parentesco la tierra pasa de hombre a hombre, del padre al hijo, por ejemplo, mientras que a la hija se le excluye de la propiedad de la tierra: En el mundo árabe, ella recibirá una tercera parte de la tierra y su hermano las dos terceras partes; con lo cual será desigual la repartición de las condiciones de vida económicas y esta desigualdad atraviesa el parentesco, volviéndose un atributo de las relaciones de parentesco, de las relaciones entre padre e hijos y padre e hijas, entre madre e hijos, madre e hijas. Por lo tanto, no son las mismas cosas las que pasarán de generación en generación, de sexo a sexo" (Godelier; 1997: 19)12.

Cabe preguntarse: ¿En dónde comenzó esta distinción y supremacía entre los géneros?, ¿Cuáles podrían ser los pilares de la dominación masculina?, ¿Cómo se podría ir disolviendo esta jerarquía que beneficia exclusivamente al ámbito masculino? Las respuestas se pueden encontrar en las aportaciones de Godelier (1997), Bourdieu (2000) y Héritier (1996 y 2007) como se aprecia a continuación:

Con respecto a la supremacía masculina Héritier (1996) argumenta:

"El mito legitima el orden social ...Sin embargo, no todas las sociedades han elaborado mitologías propiamente dichas para <<fundamentar>> la dominación masculina y darle sentido. Pero todas tienen un discurso ideológico, un cuerpo de pensamiento simbólico que desempeña esta función de justificar la supremacía del hombre a los ojos de todos los miembros de la sociedad, a los de las mujeres lo mismo que a los de los hombres, pues unas y otros participan por definición de la misma ideología, inculcada desde la infancia" (Héritier; 1996: 217-218).

\footnotetext{
${ }^{12}$ Subrayado mío.
} 
Este orden mítico o su análogo en el discurso ideológico encuentran una justificación por las diferencias físicas y la carga simbólica que se le otorga a los cuerpos diferentes como argumenta Bourdieu:

"...las diferencias visibles entre el cuerpo femenino y el cuerpo masculino las que, al ser percibidas y construidas de acuerdo con los esquemas prácticos de la visión androcéntrica, se convierten en el garante más indiscutible de significaciones y de valores que concuerdan con los principios de esta visión del mundo; no es el falo (o su ausencia) el fundamento de esta visión, sino que esta visión del mundo, al estar organizada de acuerdo con la división en géneros relacionales, masculino y femenino, pueden instituir el falo, constituido en símbolo de la virilidad ....No es que la necesidad de la reproducción biológica determinen la organización simbólica de la división sexual del trabajo y, progresivamente, de todo el orden natural y social, más bien es una construcción social arbitraria de lo biológico, y en especial del cuerpo, masculino y femenino, de sus costumbres y de sus funciones, en particular de la reproducción biológica, que proporciona un fundamento aparentemente natural a la visión androcéntrica de la división de la actividad sexual y de la división sexual del trabajo y, a partir de ahí, de todo el cosmos. La fuerza especial de la sociodicea masculina procede de que acumula dos operaciones: legitima una relación de dominación inscribiéndola en una naturaleza biológica que es en sí misma una construcción social naturalizada" (Bourdieu; 2000: 37) ${ }^{13}$.

Al introducir el debate entre la naturaleza biológica y su construcción social, Héritier (1996) comienza a trazar una nueva línea de la discusión, sugiriendo el principio de la valencia diferencial de los sexos, que define de la siguiente manera:

"...expresa una relación conceptual orientada, si no siempre jerárquica, entre lo masculino y lo femenino, traducible en términos de peso, temporalidad (anterior I posterior) y valor. Dicha relación conceptual es fácilmente identificable en el tratamiento terminológico de la relación central de hermandad (los pares hermano / hermana y hermana / hermano) y de las posiciones de parentesco que se desprenden" (Héritier; 1996: 23). Y más adelante continua: "...las perdidas de sustancia sanguínea que las mujeres experimentan regularmente sin poder oponerse a ello ni frenar el curso de las cosas. Los hombres no pierden su sangre sino es voluntariamente, por así decirlo: en ocasiones que ellos mismos han buscado, como la caza, la guerra o la competición. La perdida de sustancia no afecta, pues, a los individuos de la misma manera. La perdida de sustancia espermática también es controlable, y muchos sistemas sociales e ideológicos preconizan y organizan este control" (Héritier; 1996: 25).

Dicha conceptualización, la retoma años después diciendo:

"Las mujeres no son dominadas por su condición sexual de mujeres, ni porque tengan una anatomía diferente, ni porque naturalmente tengan maneras de pensar y de actuar diferentes a la de los hombres, ni porque son frágiles o incapaces, sino porque tienen el privilegio de la fecundidad y de la reproducción de varones. La anticoncepción las libera del mismo tema por el que fueron hechas prisioneras" (Héritier; 2007: 128)14.

\footnotetext{
${ }^{13}$ Subrayado mío.

${ }^{14}$ Subrayado mío.
} 
Godelier habla de la simbología propia de la superioridad masculina de esta forma:

"Los signos de superioridad masculina -signos que son buscados, inventados- siempre tienen un carácter arbitrario. Cuando parte de que la dominación masculina parece derrumbarse, se tiene que recurrir al reinvento de nuevas pruebas de dicha supuesta superioridad ...En ciertas sociedades, las mujeres tejen porque son inferiores. En otras sociedades, los hombres tejen porque son superiores. La materialidad del acto de tejer no dice nada, pero siempre está cargada de sentido, y se nota un desplazamiento constante de sentido" (Godelier; 1997:26) Y más adelante continua: "...por una parte, uno ve constantemente una violencia física, una violencia psicológica, una violencia social ejercida sobre las mujeres, mediante el desprecio, la burla: las mujeres no saben treparse a los árboles, no pueden matar a un enemigo, no saben usar un arco; claro, nunca lo han hecho por lo cual no saben hacerlo. Ahí tenemos una retroacción, uno tiene evidencias sensibles ya que están creadas todas las condiciones de la retroacción, de la retroalimentación del sistema" (Godelier; 1997:28)

Sin embargo, se debe realizar la siguiente acotación:

"Otros hombres: estamos bajo el cuidadoso y persistente escrutinio de otros hombres. Ellos nos miran, nos clasifican, nos conceden la aceptación en el reino de la virilidad. Se demuestra hombría para la aprobación de otros hombres. Son ellos quienes evalúan el desempeño" (Kimmel; 1997: 55) Y continua: "El hecho que esos hombres prueben su virilidad a los ojos de otros hombres es a la vez consecuencia del sexismo y uno de sus puntales principales. "Las mujeres tienen, en la mente de los hombres, un lugar tan bajo en la escala social de este país, que resulta inútil que tú te definas a ti mismo, en los términos de una mujer", expresó el dramaturgo David Mamet. "Lo que los hombres necesitan es la aprobación de los propios hombres". Las mujeres llegan a ser un tipo de divisa que los hombres usan para mejorar su ubicación en la escala social masculina.

(Hasta esos momentos de heroicas conquistas de mujeres, conllevan yo creo, una corriente de evaluación homosocial). La masculinidad es una aprobación "homosocial". Nos probamos, ejecutamos actos heroicos, tomamos riesgos enormes, todo porque queremos que otros hombres admitan nuestra virilidad" (Kimmel; 1997: 55-56)

Por último, en su trabajo titulado: "Masculino / femenino II. Disolver la jerarquía". Héritier identificó que la única manera de disolver la jerarquía que beneficia en exclusiva al género masculino en relación con lo femenino, se encuentra en la capacidad de las mujeres de controlar su sexualidad, con el uso adecuado de los métodos anticonceptivos, pues “...la anticoncepción se aplica en el lugar mismo de la dominación" (Héritier; 2007: 210). Otro de los campos que debe conquistar la mujer para abolir la dominación es obteniendo su independencia económica y su ingreso a la educación, como alternativas viables por las cuales las mujeres pueden obtener su autonomía.

"Se puede entonces razonar que los medios de regular la procreación, de controlar los nacimientos, no sólo son accesibles a las mujeres sino que están reservados para ellas.

\footnotetext{
${ }^{15}$ Todos los subrayados en ambas citas son míos.
} 
Esto es parcialmente cierto en las zonas más desarrolladas del mundo, aquellas en las que las mujeres tienen ...el mayor acceso a la educación y a la igualdad profesional, aquellas finalmente donde no están tan sometidas a presiones religiosas o ideológicas ...la condición femenina ha cambiado considerablemente, en lo jurídico y en las costumbres, durante este medio siglo en el mundo occidental, con varias y notables modificaciones de la relación hombre / mujer. La cuestión de fondo que aquí se plantea es saber en la práctica qué lugar ocupa el control de la procreación por parte de las mujeres en esa evolución" (Héritier; 2007:214)

En resumen, la autoridad masculina se fundamenta en las estructuras de significación y poder que culturalmente se les atribuyen a los cuerpos, aunado a la apropiación de los hijos que son procreados por las mujeres quienes son las victimas del significado negativo que se le otorga a su condición biológica; es decir, la capacidad de reproducir lo semejante y lo diferente, y por su incapacidad de controlar el sangrado menstrual a diferencia de los hombres, que no tienen la capacidad de la reproducción y controlan las situaciones que exige derramar su sangre-semen. Estas ambivalencias colocan a las mujeres en una desventaja tanto simbólica como física frente a los hombres, quienes justifican y ejercen su dominio sobre sus esposas y sus hijos (procreados por ellas). Pero en todo sistema de poder (dominio) siempre existe su dicotomía, es decir, la resistencia.

A partir de la lectura de James Scott en "Los dominados y el arte de la resistencia", identifico que los grupos subordinados se encuentran cultural y geográficamente ubicados en un cierto espacio social que en un principio fue asignado por el grupo hegemónico. Pero con el paso del tiempo ese espacio físico terminó siendo apropiado y modificado por sus ocupantes, los cuales crearon espacios o trincheras propias de su clase social que servirán como sitios de interacción y oposición al sistema opresor. Es en estos sitios que -retomo de Scott:

"En circunstancias normales, los subordinados tienen interés de evitar cualquier manifestación explicita de insubordinación ...minimizar las exacciones, el trabajo y las humillaciones que reciben. La reconciliación de estos dos objetivos, que parecen ir en sentido contrario, se logra en general insistiendo en aquellas formas ...que evitan una confrontación abierta con las estructuras de autoridad ...Sólo cuando fracasan las medidas menos drásticas, cuando la subsistencia se encuentra amenazada o cuando hay signos de que puede atacar con relativa seguridad, el campesinado se atreve a seguir el camino del desafío abierto y colectivo. Por esa razón, el discurso oficial entre el dominante y el subordinado está lleno de formulas de servilismo, de eufemismos y de indiscutidas pretensiones de estatus y de legitimidad" (Scott; 1990:113).

Por su parte Ortner (1996), nos hace recordar que siempre existen otras categorías como son: la "...edad, género, estatus, y otras formas de diferencia en relación a las posiciones que ocupan los diversos sujetos en cada situación" (Ortner; 1996: 175). Las cuales, a pesar de su origen hegemónico están presentes en las mentes de los subordinados, quienes las utilizan de manera 
tan "natural" entre ellos mismos, a pesar de que realizan actos de resistencia contra el sistema hegemónico. Entonces ¿De qué manera se manifiesta la resistencia femenina frente a lo masculino en el municipio de Tepetlaoxtoc?, sobre la base de Ortner, ¿En qué medida el discurso de las tepetlaoxtoqueñas está influenciado por el discurso hegemónico al referirse a mujeres que viven en unión consuetudinaria mesoamericana, madres solteras o que sostienen relaciones lésbicas? Y ¿Qué comentarios surgen de las mujeres para este "otro tipo de mujeres"? En otro tiempo se podrían responder de una manera veraz, pero que requerirá de una investigación más profunda propia del ámbito del doctorado.

Posturas teóricas de la antropología del espacio mexicano.

Tomando en consideración que la Zona Metropolitana de la Ciudad de México es un caleidoscopio cultural, en el cual se realizan diversas formas de apropiación y construcción del espacio, como lo muestra Nieto:

“...la periferia metropolitana está diferenciada, socialmente, en una zona oriente de asentamientos populares más o menos recientes; una zona norte de gran dinamismo industrial donde la población que la habita trabaja como empleados y obreros de esas empresas; y finalmente una zona poniente, lugar de asentamientos de sectores medios y altos, entre los que están intercaladas franjas de colonias populares. El sur, por último, reproduce la heterogeneidad social del poniente, pero conserva en su interior una dinámica red de pueblos semirrurales que, en algunos casos, marcan la frontera agrícola de la urbe. Esta parte de la ciudad se articula tanto al poniente como al oriente dependiendo de situaciones de vialidad y físicas (lago de Xochimilco, serranía del Ajusco, etc.), lo que da lugar a una gran heterogeneidad en los distintos usos del tiempo del que disponen las personas y de los espacios que conocen, habitan y utilizan en la ciudad" (Nieto; 1998: 236).

Esta investigación se desarrolló en algunos barrios, pueblos y rancherías del nororiente del Estado de México, y en esta sección del ensayo trataré de exponer brevemente las diferencias entre los espacios citadinos y los pueblos del valle de México.

Características y diferencias entre la ciudad y el pueblo.

Para comenzar con este apartado es necesario definir territorio, para lo cual, cito de Portal:

"El territorio fue y sigue siendo un espacio donde habitamos con los nuestros, donde el reclamo del antepasado y la evocación del futuro permite reverenciarlo como un lugar que aquél nombró en ciertos límites geográficos y simbólicos. Nombrar el territorio es asumirlo como una extensión lingüística e imaginaria; en tanto que recorrerlo, pisándolo, marcándolo en una forma u otra, es darle entidad física que se conjuga, por su puesto en el acto denominativo" (Portal; 1997: 75). 
Tomando en cuenta que todas las transformaciones físicas y simbólicas que será objeto el territorio; son el resultado de las prácticas sociales y la cultura local, que modifica al espacio a su plena conveniencia. Por lo tanto, se puede hablar que existen dos tipos de territorios: el urbano y rural con características diferentes y en ocasiones en aparente oposición una de la otra. En este sentido, una pesada tradición teórica encabezada por Castells (1982), dicta que los pueblos con el tiempo se transformarán en sociedades urbanas. Estas comprenden las siguientes características: tienen una dimensión ${ }^{16}$, multiplicidad (segmentación) ${ }^{17}$, provocando el anonimato, la densidad ${ }^{18}$ y heterogeneidad social ${ }^{19}$. Y está en oposición a las sociedades rurales, en las cuales: los habitantes no son anónimos, es más, se comparten lazos de parentesco tanto consanguíneo como ritual, existe una homogeneidad social más evidente con fuertes lazos comunitarios, y por último no existe una segmentación y densidad tan marcada, en comparación a las sociedades urbanas. Por lo tanto:

"... "sociedad urbana" ha sido pensado ante todo en oposición a "sociedad rural", al analizar el paso de la segunda a la primera ...como la evolución de una forma comunitaria a una forma asociativa, caracterizada ante todo por la segmentación de los papeles, la multiplicidad de las pertenencias y la primacía de las relaciones sociales secundarias (a través de las asociaciones específicas) sobre las primarias (contactos personales fundados en la afinidad efectiva)"(Castells; 1982: 95). Pero más adelante apunta: "...si bien es verdad existen diferencias entre ciudad y campo, estas no son más que la expresión empírica de una serie de procesos que producen al mismo tiempo toda una serie de efectos específicos a otros niveles de la estructura social. En otras palabras, hay una variación concomitante entre la evolución de las formas ecológicas y de las formas culturales y sociales, sin que se pueda afirmar por ello que esta covariación sea sistemática ni, sobre todo, que las segundas sean producidas por las primeras" (Castells; 1982: 100).

Por ende, el uso del concepto "cultura urbana" por parte de los discursos de algunos grupos en el poder, se debe ver como un intento de acabar con las unidades ecológicas particulares, como

\footnotetext{
${ }^{16}$ Definido como: “...cuanto mayor es, mas amplio es el abanico de variación individual y más grande será la diferenciación social ...debilitamiento de los lazos comunitarios” (Castells; 1982: 98).

17 “...la multiplicación de las interacciones produce la segmentación de las relaciones sociales y suscita el carácter “esquizoide” de la personalidad urbana” (Castells; 1982: 98).

${ }^{18}$ Interpretado como: “...refuerza la diferenciación interna, porque, paradójicamente, cuanto más próximo se está físicamente, más distante son los contactos sociales a partir del momento en que resulta necesario no comprometerse más que parcialmente en cada una de las pertenencias” (Castells; 1982: 98).

${ }^{19}$ Se considera que "...permite la fluidez del sistema de clases y la taza elevada de movilidad social explica que la filiación a los grupos no sea estable, sino obligada a la posición transitoria de cada individuo: hay por lo tanto, predominio de la asociación (basada en la afinidad racional de los intereses de cada individuo) sobre la comunidad" (Castells; 1982: 98).
} 
son: los pueblos ${ }^{20}$, barrios ${ }^{21}$, unidad de vecindad 22 . A manera de que éstas, "evolucionen" y se incorporen a la practica modernista de la ciudad, y con esto, al desarrollo económico nacional.

Por lo tanto, los pueblos originarios deben ser ilustrados como anteriormente se comentó: Espacios físicos territoriales y simbólicos que remiten a un pasado remoto con un origen prehispánico o colonial que pueden estar sustentado en evidencias documentales, como son: códices, mapas, cartas o nombramientos coloniales, y reforzado por la historia oral (fundación mítica, leyendas de los santos patrones, mitos populares, etc.), monografías locales, la traza colonial, zonas arqueológicas, evidencias prehispánicas o hechos duros temporalizados; es decir, edificios con fechas de su construcción o modificación. Se utilizan puntos de referencia como son montañas, cerros, cuevas o ríos, como una manera de presentar los espacios territoriales que forman parte de su cosmovisión. Consecuentemente, en los pueblos indígenas, se tratan de asentamientos en los cuales los espacios públicos o "espacios de proximidad"23 relevantes son el atrio con su iglesia, las capillas, el mercado, edificio de gobierno, el kiosco del parque y la casa del patrimonio regional o de la cultura. Además, los oriundos se asumen como descendientes simbólicos del santo patrón de su pueblo, mismo que los procura de sus necesidades y los protege frente a las adversidades externas a su territorio. Por último, el conjunto de estos elementos son utilizados como referentes de la identidad colectiva generando un habitus, que hace partícipe a todos los oriundos en base a los "usos y costumbres", para excluir a los avecindados y de servir como elemento diferencial frente a las poblaciones circunvecinas con las que se puede compartir algún tipo de reciprocidad, ya sea: ceremonial, ritual, danza, económica o matrimonial.

Sabemos que la gran mayoría de los pueblos de la región de Mesoamérica, están conformados por barrios, cuyos orígenes se remontan al periodo prehispánico:

\footnotetext{
${ }^{20}$ Entendidos hasta este momento como: un espacio “...bastante homogéneo, con débil diferenciación interna, y donde las relaciones espaciales esenciales son circulación en torno a los centros de actividades” (Castells; 1982: 125).

${ }^{21}$ Comprendido como: “...está también provisto de equipamientos colectivos y accesibles al peatón; pero, además, está constituido en torno a una subcultura y representa una línea de demarcación significativa en la estructura social, pudiendo llegar a una cierta institucionalización en términos de la autonomía local” (Castells; 1982: 125).

${ }^{22}$ Definida como: “...la base de la habitación y de las redes de ayuda recíproca y de contactos personales a que da lugar” (Castells; 1982: 125).

${ }^{23}$ Comprendido como: “...los espacios públicos accesibles a pie desde la vivienda, como son las calles, banquetas plazas y otras infraestructuras comunes en las colonias populares. Aludiendo así a un ámbito circunscrito al entorno de la vivienda en el que es posible desplazarse caminando, y donde cada quien puede hacer la experiencia de lo familiar y conocido, sin que tal experiencia pueda darse por descontada, ya que sería aventurado suponer altos grados de conocimiento recíproco entre los habitantes, la existencia de una comunidad local o de fuertes sentimientos de pertenencia y de construcción de identidades basadas en la localidad" (Duhau-Giglia; 2004: 175-176).
} 
"Cuando las fuentes escritas en español en el siglo XVI nos hablan de barrio, hemos de entender que se refieren al término náhuatl Calpulli. No era estrictamente un espacio demarcado donde vivía una parte de la población de la ciudad. Era mucho más que eso: designaba al grupo social emparentado, unido por vecindad, profesión, templo y dios protector común, que tenían dirigentes para asuntos internos y que pagaban en conjunto sus tributos en trabajos comunales y en la participación en la guerra. Era un grupo estrechamente unido, en el que se veía muy mal que sus miembros contrajesen matrimonio con gente de otro calpulli" (López Austin; 1985: 25). Debido a lo anterior. "El calpulli no era solo una organización de barrio, sino una institución social de hondas raíces y de múltiples ligas, en la que sus componentes creían descender de un antepasado común, muchas veces identificado con el dios patrono" (López Austin; 1985: 29). En apoyo a lo expresado, cito de Redfield: "...cada calpulli poseía en común tierras separadas y distintas de las tierras de los demás calpulli. Estas tierras no se podían vender, y únicamente miembros de ese calpulli podrían establecerse en ellas" (Redfield; 1982: 86).

Y en la actualidad, los barrios pueden ser definidos como:

"Una región física y socialmente determinada, cuyo principal símbolo es un santo patrón que reside en una capilla o ermita que recibe por lo menos una veneración festiva al año. Que está sujeta a las órdenes de una Iglesia o catedral que alberga al santo patrón del pueblo. Además, los habitantes del lugar se reconozcan, y sean reconocidos como parte del mismo; no sólo por los vecinos, sino de ser posible por miembros de otro barrio, y que la capilla sea atendida por mayordomos, que en su mayoría son originarios del lugar" (Rivera; 2004: 88)24.

Los espacios públicos y privados en los pueblos mexicanos.

El espacio público se puede entender como:

“...aquel espacio que no es privado (destinado al uso exclusivo de sus habitantes $u$ ocupantes) y constituye el medio físico que permite poner en relación a los diferentes espacios privados. Es el espacio que está entre los espacios individuales de las viviendas y edificaciones privadas, el espacio físico entre las casas particulares, donde se encuentran los servicios y vialidades disponibles para todos los habitantes. Es un espacio material, definido en términos racionales (es decir, en oposición con otro de otra índole) a partir de un criterio jurídico" (Duhau-Giglia; 2004:171).

Entre otras cosas se han caracterizado a los espacios públicos como zonas peligrosas, con frecuentes conflictos por el espacio y en ocasiones como espacios intersticiales destinados al

\footnotetext{
${ }^{24}$ A continuación, resumo mi postura sobre la temática de la endogamia de barrio en los pueblos mesoamericanos: “...La lógica estructural de la práctica de la endogamia socialmente reconocida y aceptada en (las) microrregiones de Mesoamérica encuentra su existencia en cuatro elementos que forman un cinturón de fuerza que protege a la población contra lo extraño, disfrazado en el argumento de: proteger nuestros usos y costumbres. Dichos elementos son: 1) trajes impermeables que genera la comunidad sobre la base de procesos de identidad específicos; y que provocan la residencia longeva de sus habitantes y formas preferenciales de matrimonio. Además, 2) el reconocimiento de los límites del tabú del incesto en la parentela para realizar alianzas con vecinos de la región. Aunados a: 3) los procesos históricos que marcaron a la comunidad; y fomentados por: 4) relativa inaccesibilidad geográfica que tiene algunas de las microrregiones del país. Se debe mencionar, que los cuatro puntos anteriores interactúan entre sí para evitar lo más posible el contacto con el otro” (Rivera; 2004: 135-136).
} 
tránsito, los cuales, tienen una lógica y reglas comunes que deben ser conocidas por todos los transeúntes, a manera de lograr una negociación adecuada para evitar una confrontación que podría finalizar con la violencia física. Por lo tanto, se entiende que debe existir una institución reguladora de la violencia legítima a modo de evitar la anarquía tanto en el ámbito nacional como regional o local. A pesar de que en la mayoría de los casos, los problemas locales se resuelven mediante los métodos consensados por sus habitantes. Otra de las características de este espacio, es que en él se encuentran los centros de trabajo o sitios que se consideran como lugares de castigo, y de la rutina diaria, mismos que afectan de manera diferente tanto a los hombres, mujeres, niños, ancianos y jóvenes que se ven obligados a utilizar este espacio. En oposición, aparece el espacio privado, que se caracteriza por ser un sitio para descansar, en el cual sus ocupantes establecen sus propias reglas, normas, obligaciones y derechos, además de contar con la capacidad de imponer el orden de las cosas materiales. Cabe mencionar, que socialmente este espacio está considerado como un sitio de seguridad individual e intimidad personal y como un espacio intersticial para las personas que no están familiarizadas con el.

Así, se puede entender que:

"...los dominios de la calle y de la casa marcan algo más que espacios distintos, y permiten descubrir papeles sociales e ideologías, (valores), acciones y objetos específicos ....siempre están asociados ...para determinada región en el mundo social. Así, todos los papeles sociales que, para su articulación, implican una ideología sustantiva (o de sustancia) y en consecuencia están vinculados al cuerpo y a la sangre ...deben darse por la casa. Pero todos los papeles sociales que implican elección y voluntad ...como ...formas de corporación civil, son parte del mundo público, del dominio de la calle" (DaMatta; 2002:105) ${ }^{25}$.

En estos momentos cabe realizar dos preguntas ¿Podría existir la disociación entre el espacio público con el privado y viceversa en los pueblos mexicanos? y ¿En qué situaciones se puede dar? Considero que sí se puede disolver temporalmente la frontera entre el espacio público y privado, pero en situaciones particulares como son las reuniones sociales (tomar un café o té), las fiestas de ritos de paso personales o con motivo del festejo del santo patrón de la localidad, circunstancia que permite la entrada masiva de invitados y vecinos al solar familiar. Sin olvidar que durante la fiesta del pueblo, se aprueba la oferta de pequeños servicios como son franeleros, acomodadores de vehículos, changarreros (panaderos, chachareros, algodoneros), comerciantes, el vocinero ${ }^{26}$, vendedores y revendedores de boletos del baile, del jaripeo 0 palenque, también abundan los guardarropas, cargadores, juegos de azar, el "toques toques",

\footnotetext{
${ }^{25}$ Paréntesis internos míos.

${ }^{26}$ Que consiste en un varón que carga una bocina y canta alguna canción de banda o ranchera, según la solicitud. A cambio, espera un poco de comida y bebida de fiesta o una remuneración económica. También vende discos compactos con música de distintos géneros vaqueros.
} 
toro mecánico, la fotografía de la monta, etc. Y la transformación temporal del territorio, como cerrar calles públicas con motivo de la feria, usar el jardín o garaje de la casa para instalar un negocio de alimentos y / o bebidas embriagantes, renta de baños públicos ${ }^{27}$, emplear el portón como guardarropa a cambio de una tarifa específica durante el tiempo que duré el baile, o un terreno de siembra para ser utilizado, ya sea como estacionamiento público, para instalar el jaripeo o palenque portátil -como se verá más adelante- y como sitio para el baile del pueblo. En este último caso, la reunión toma un carácter semiprivado al convocar un grupo musical de renombre que toque banda, ranchero o duranguense por parte de una familia 0 asociación de familias que ven en la fiesta del pueblo, una oportunidad de realizar un negocio tras la venta de los boletos del espectáculo. Y el evento reclama su carácter semipúblico, al ser anunciado mediante pintas, cartelones e incluso anuncios por la radio para invitar a los habitantes de los pueblos circunvecinos y todos aquellos que estén interesados a pesar de su distancia territorial. Circunstancias y acontecimientos que permiten el intercambio entre afines, el encuentro con el "otro", realizar alianzas e intercambios, confirmar identidades y pertenencias, romper con la monotonía, entre otras muchas cosas.

Otra lectura de la primera premisa (¿Podría existir la disociación entre el espacio público con el privado y viceversa en los pueblos mexicanos?) diría, que en condiciones normales (fuera del ciclo festivo de los pueblos), el espacio público encuentra su límite frente a un carácter fijo como puede ser una barda, fachada, zaguán, portón, jardín, reja, alambrada o una puerta, elementos que denotan el comienzo del ámbito privado. Sin embargo, cuando algún conocido o familiar pasa del espacio publico al privado con una autorización previa de los ocupantes, éstos atenderán a su visita ya sea en la sala 0 el recibidor; espacios sociópetos ${ }^{28}$ que deben ser vistos como la última frontera antes de entrar en los sitios propios de la intimidad (como son habitaciones, baños, cocina, etc.). En el sentido opuesto, los balcones o terrazas que caracterizan a las construcciones de algunos solares, deben ser vistos como una extensión simbólica del ámbito privado hacia la calle.

\footnotetext{
${ }^{27}$ A pesar que la mayoría de los varones utilizan la vía pública para orinar.

${ }^{28}$ Cito la definición de Hall: “....algunos espacios, como las salas de espera de los ferrocarriles, tienden a mantener apartadas a las personas unas de otras. Él llamaba esos espacios sociófugos. Otros, como las mesas de venta de las tiendas antiguas o los veladores de las terrazas de los cafés franceses, tienden a reunir a la gente. A éstos los llamaba sociópetos” (Hall; 1998:134).
} 
Los espacios temporales en las fiestas de los pueblos mexicanos.

Con respecto a los espacios temporales, puedo citar:

"Se trata de espacios de lo festivo y del intercambio y espacios de las rutinas cotidianas que físicamente pueden ser uno y el mismo espacio. Esta temporalidad interesa algunos lugares específicos y los transforma en días y circunstancias determinados en espacios para el encuentro de lo diferente. Es el caso de las infraestructuras -aunque generalmente mínimas- para el deporte (canchas de futbol) o para el culto religioso, las cuales constituyen lugares donde esta experiencia del extraño es posible. Al igual que en la calle, en los momentos en que ésta se transforma en el escenario para la fiesta o el mercado" (Duhau-Giglia; 2004:182)

El espíritu humano iluminó a los hombres en el ámbito mundial para formular las nociones del espacio público y privado dentro de cada una de sus sociedades, pero otra manifestación cultural que está presente al remitir a la idea del espacio, es el tiempo. Se pueden rescatar las aportaciones de Spier (1975) y Vargas (2007), quienes hacen referencia al origen, las concepciones y la manera en que la antropología ha utilizado la noción del tiempo. Debo aclarar, que en esta investigación solamente se presentarán parcialmente los argumentos de este par de investigadores para ofrecer una aproximación al concepto.

"El hombre tiene consciencia de los cambios en su cuerpo y en el mundo exterior, cambios en el día y la noche, la sucesión de las estaciones, y su naturaleza recurrente. Pero el registro de los periodos de cambio por medio de horas, días y años, es un concepto humano, proyectado sobre el mundo y que no es conocido por ningún otro animal" (Spier; 1975: 343) Y posteriormente afirma: "El origen de una medición más precisa debe buscarse en la observación sacerdotal de los solsticios y los movimientos de las estrellas, aunado al cómputo de meses y días, para el propósito de regular los rituales ...Las fiestas "fijas" y "movibles" de nuestros calendarios eclesiásticos se deben a que dependen, una de ellas, de los eventos astronómicos, otra de la cuenta por días y meses" (Spier; 1975: 345).

Sumado a lo anterior, Vargas (2007) comenta, que:

"La reflexión sobre nuestras concepciones del tiempo muestran el lugar que éstas juegan dentro de las relaciones interpersonales, las relaciones entre grupos sociales y las relaciones entre naciones y grupos de naciones. En resumen, nuestras concepciones del tiempo apoyan y justifican las relaciones de poder. ...la retórica de la temporalidad es una de las formas por medio de las cuales el Estado y las élites, en general, buscan neutralizar ante nuestros ojos las relaciones de desigualdad" (Vargas; 2007: 42-43). 


\subsection{HIPÓTESIS.}

La aparición durante los años 80’s de los primeros centros educativos de nivel básico superior (secundarias) en el municipio de Tepetlaoxtoc de Hidalgo junto con la necesidad de los jóvenes por emigrar a los municipios vecinos -principalmente el municipio de Texcoco-, para continuar sus estudios en el ámbito medio superior y superior, provocó que se crearan espacios de interacción para los adolescentes en dos niveles: Primero, entre los habitantes de diversos pueblos, pero del mismo municipio (Tepetlaoxtoc). Segundo: Permitió la formación de nuevas redes sociales, pero con habitantes de otros municipios vecinos del Acolhuacán Septentrional. Circunstancia que en su momento fomentó la formación de parejas de novios que estaban despertando al mundo de la sexualidad, pero fuera de la autoridad física y moral de sus padres 0 cualquier otro pariente, donde las señoritas se relacionarían con varones portadores de diversos principios de masculinidad, que a través de un escrutinio social entre los mismos varones, se definiría la hombría de cada sujeto -como lo sugieren Kimmel (1997) y Granados (2002)- y se determinaría sí ese varón asemeja o no, los principios de la masculinidad a la que está acostumbrada la señorita.

Las fiestas patronales, satelitales, danzas regionales, los simulacros festivos ${ }^{29}$, juegos masculinos y bailes populares que se realizan durante el mes de enero al interior de este municipio del Acolhuacán Septentrional, son espacios que permiten algunas veces más, en otras menos, la interacción social entre sus diversos tipos de asistentes (transeúntes, consumidores, espectadores, etc.), pero también deben ser consideradas como arenas políticas, simbólicas y campos de disputa por el capital social personal o familiar entre los distintos organizadores y demás miembros participantes de los eventos que acompañan a la celebración. Pues no se debe perder de vista, que: "<<La participación es meramente otra forma de ver al poder > ...Estudiar la participación es estudiar la estructura de poder en operación y, como la estructura de poder, la participación es siempre recíproca" (Varela; 2005: 47).

Sobre el supuesto que los deseos sexuales son propios de ambos géneros, y las mujeres son vistas como un objeto del deseo sexual masculino -Pateman (1995), Montesinos (1999) y Bourdieu (2000). "Tal es el poder que ejerce la mujer sobre el hombre (en su calidad de símbolo erótico colectivamente construido), que generalmente se le concede la capacidad exclusiva del

\footnotetext{
${ }^{29}$ Refiriéndome a las representaciones laborales que realizan las mayordomías satelitales de los gañanes, tlachiqueros, albañiles y arrieros. Como se verá más adelante.
} 
poder de la seducción" (Montesinos; 1999: 260) ${ }^{30}$. Esta circunstancia, provoca que su asistencia y / o participación de las señoritas casaderas y mujeres solteras en los juegos masculinos (palenques, jaripeos, carreras de caballos, etc.) y bailes populares (públicos o semiprivados), las convierta en signos de disputa y competencia simbólica entre los varones presentes, que son "víctimas" de la sensualidad socialmente construida, y que a su vez "...le otorgan a la mujer moderna un recurso, subjetivo pero tangible, para alcanzar sus objetivos personales de poder" (Montesinos; 1999: 265). Este contexto en general, le concede a la mujer la capacidad de aceptar o rechazar la autodonación sexual o relaciones sexuales ocasionales, que pueden ser respaldadas por el uso de anticonceptivos ${ }^{31}$ con algunos de los varones que demostraron su virilidad (en los diversos juegos masculinos propios de esta festividad) o simplemente atraigan la atención femenina por otros motivos.

Los espacios privados propios del descanso $0<<$ del cuerpo y la sangre $>$, son temporalmente física y simbólicamente reducidos ante los crecientes espacios públicos que caracterizan a los tiempos festivos de los santos patrones mesoamericanos. Es en este contexto de celebración, donde los varones pueden hacer gala de sus diversos capitales sociales y medallones a manera de mostrarlos e incrementarlos frente al resto de la comunidad, ya sea en actividades de prestigio o en diversas demostraciones de virilidad. Sin olvidar, que buena parte de la galantería de los capitales y el honor masculino (virilidad y pulsión sexual)32, se enfocan principalmente hacia las mujeres desprotegidas, es decir: "...todo cuerpo de mujer que no es apropiado, cuidado y defendido por un propietario cuyo derecho está fundado sobre la filiación y la alianza, y cuyo uso sexual, el que se hace o el que se obliga a hacer, está orientado hacia la procreación, pertenece potencialmente a cualquier hombre cuya pulsión sexual debe satisfacer ...para uso sexual y búsqueda de placer, usos que, por intermedio del acto sexual, son indisociables del uso procreativo" (Héritier; 2007: 251)33. Elementos, que conforme se van sumando a los diversos procesos de globalización y de la información mediática, permiten la asistencia y participación tanto de hombres como de mujeres provenientes de diversos lugares, quienes gozan de un carácter de individuos anónimos frente a los demás concurrentes. Este carácter de individuos, les podría permitir el realizar comportamientos extravagantes que en otros lugares y

\footnotetext{
${ }^{30}$ Subrayado mío.

${ }^{31}$ La hipótesis parte del supuesto -retomo de Héritier-, que: "Conocer el mismo rol que juegan los gametos y favorecer la anticoncepción, es decir, la libre elección, son ciertamente los incentivos esenciales para que las mujeres, colectivamente y no sólo a través de individuos o de grupos particulares, accedan a la trascendencia” (Héritier; 2007:107)

32 "La manifestación ejemplar de la masculinidad es realizar el <<acto sexual >>” (Pateman; 1995: 275).

${ }^{33}$ Subrayado mío.
} 
circunstancias no los podrían realizar, incluyendo relaciones sexuales ocasionales con uno 0 más varones o mujeres, pero respaldados por diversos métodos anticonceptivos, porque: “...el hecho mismo de que el beneficio ya no sea exclusivo del hombre es la razón por la cual el uso de métodos anticonceptivos por parte de las mujeres es percibido por todos los fundamentalismos, sin excepción, como la puerta de salida hacia la liberación femenina, ya que obligadamente acompaña a su emancipación. Ese mismo uso es también percibido por muchos hombres como una licencia suplementaria que se les ofrece para usar libremente el cuerpo de las mujeres liberadas del temor al embarazo no deseado" (Héritier; 2007: 253).

$\mathrm{Si}$, "...uno de los rasgos ... del matrimonio es que no se originan en los individuos, sino en los grupos interesados" (Lévi-Strauss; 1991: 22) y que "La práctica legítima de la sexualidad, aunque pueda parecer cada vez más liberada de la obligación matrimonial, permanece ordenada y subordinada a la transmisión del patrimonio, a través del matrimonio, que sigue siendo uno de los caminos legítimos de la transferencia de la riqueza" (Bourdieu; 2000: 120), invita a pensar que las distintas arenas que complementan a las festividades de San Sebastián Mártir son espacios de conflicto entre varias familias honorables de la región o entre sus representantes masculinos. En ambos casos, probablemente utilizan a las arenas con dos finalidades: primero como un sitio en donde se puede mostrar e incrementar el capital social y simbólico que se haya acumulado y también como espacios en los cuales se presentan a los varones viriles (masculinidad hegemónica -con la mirada de Kimmel (1997)-) que son miembros de familias respetables y socialmente ubicables en el contexto de Tepetlaoxtoc, argumentos que se deben tomar en cuenta al momento de los distintos intercambios que pueden ocurrir con determinadas regiones, personas o familias específicas del municipio, mismas que comparten, utilizan y buscan acrecentar sus capitales simbólicos ${ }^{34}$, sociales y culturales ${ }^{35}$ que en su mayoría se debaten durante el tiempo festivo.

\footnotetext{
${ }^{34}$ Bourdieu, lo explica como: “...la adquisición de una reputación de competencia y de una imagen de respetabilidad y de honorabilidad cómodamente convertibles en posiciones políticas de notable local o nacional: se comprende por ello que sean y se sientan solidarios con el orden (moral) establecido, al cual, por otra parte, contribuyen enormemente con sus intervenciones cotidianas, de las que las declaraciones ...las posturas y las acciones políticas no son más que la forma más visible” (Bourdieu; 1991: 291).

${ }^{35}$ Que se puede definir de la siguiente manera: “...los campos legítimos, según los “mercados” -“escolar” o "extraescolar"- en los que se ofrecen, se establecen dos hechos fundamentales: por una parte, la fuerte relación que une las prácticas culturales (o las opiniones aferentes) con el capital escolar (medido por las titulaciones obtenidas) y, secundariamente, con el origen social (estimado por la profesión del padre); y, por otra parte, el hecho de que, a capital escolar equivalente, el peso del origen social en el sistema explicativo de las prácticas y de las preferencias se acrecienta a medida que nos alejamos de los campos más legítimos” (Bourdieu; 1991: 11).
} 


\subsection{LAS FIESTAS PATRONALES EN EL PUEBLO DE TEPETLAOXTOC, TEPETLAOXTOC DE HIDALGO.}

Los habitantes del municipio de Tepetlaoxtoc de Hidalgo en el Estado de México, encuentran un consuelo espiritual, protección y castigo físico en dos santos patrones centrales: Santa María Magdalena y San Sebastián Mártir, pero también reciben su respectivo culto todos los santos patrones de los barrios de Tepetlaoxtoc de Magdalena y Jolalpan, e incluyendo los demás pueblos que conforman la entidad.

La parroquia de Santa María Magdalena se ubica en frente al jardín del centro de Tepetlaoxtoc, su edificio y la extensión de su atrio son los de mayor proporción en comparación de los demás templos católicos en todo el municipio. Su construcción es posterior al siglo XVI bajo la orden de los frailes dominicos quienes dejaron evidencia material, gráfica y escrita de su estancia, incluyendo el eremitorio de la calle de "Fray Domingo de Betanzos" en el centro de Tepetlaoxtoc (a pocos metros de la parroquia de Santa María Magdalena, Ver mapa 1).

Esta casa de retiro y contemplación fue utilizada por Fray Domingo de Betanzos, quien fue uno de los iniciadores de la evangelización de la zona ${ }^{36}$. Por último, las solemnidades de María Magdalena se realizan el día 22 de julio y sus celebraciones se extienden por tres días más. La investigación no logró recabar más información sobre esta festividad.

Mapa 1

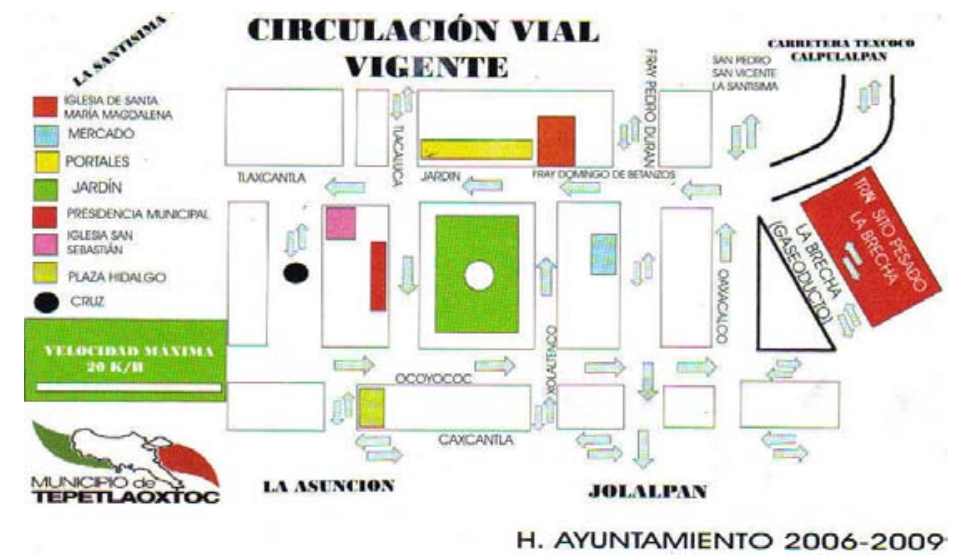

Calles del centro de Tepetlaoxtoc.

Se incluye otra copia en el Anexo 1.

\footnotetext{
${ }^{36}$ Para mayor información sobre el arribó de la orden de los dominicos al continente americano, consultar el Anexo 2.
} 


\section{San Sebastián Mártir, santo patrón de Tepetlaoxtoc.}

El día 20 de enero se celebra la fiesta de San Sebastián Mártir, su capilla se localiza a una cuadra del centro de Tepetlaoxtoc (Ver mapa 1). Su espacio físico se encuentra delimitado de la siguiente manera: al norte se descubre una cruz de piedra y un árbol al principio de una calle empedrada que no tiene nombre, pero que se utiliza para el tránsito vehicular en ambos sentidos -a partir de estos momentos la referiré como La calle de la Cruz (Ver fotografía 1). Hacia el sur, la capilla y su "atrio" topan su límite con una casona particular en óptimas condiciones. Por el este se extiende la calle Tlaxcantla que sirve para el tránsito vehicular en un solo sentido. Por último en dirección al oeste, se halla la plaza "Sebastián Mártir" que funge como un atrio poco delimitado y cuyo límite es la calle Ocoyococ que también se emplea para el tránsito vehicular en una sola dirección. Debo registrar, que las calles de Tlacaluca (Ver fotografía 2), Ocoyococ (Ver fotografía 3), Xolaltenco y La Calle de la Cruz se encuentran cerradas durante las festividades de este santo patrón, lo mismo ocurre con la calle de Jardín y Tlaxcantla. Además, la plaza Hidalgo y su respectiva calle son ocupadas con los juegos mecánicos de la feria temporal que se instala, como se verá más adelante.

\section{Fotografía 1, 2 y 3}
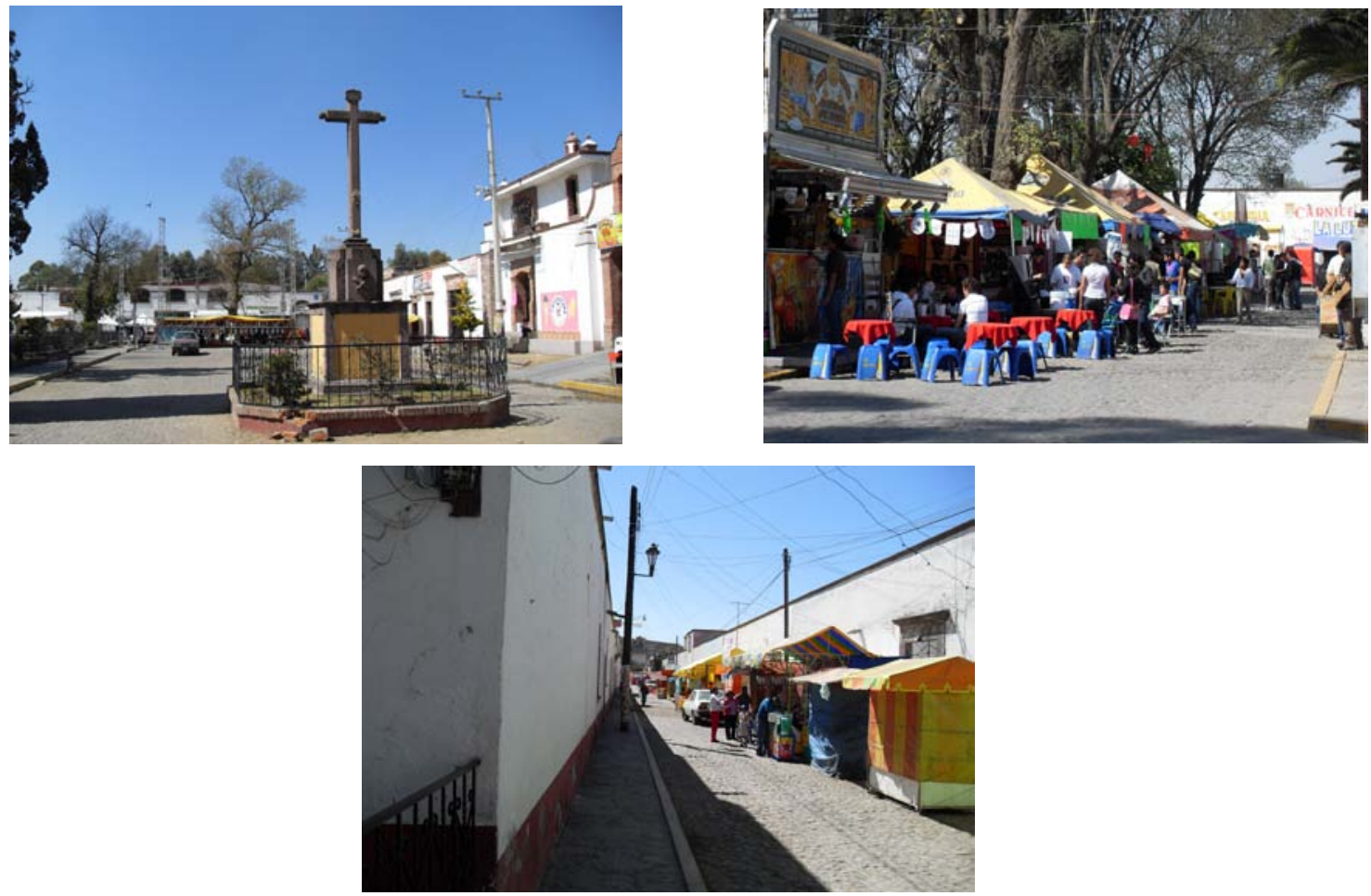

Tres de las siete calles cerradas con motivo de la fiesta de San Sebastián Mártir. 
Antes de continuar con la descripción e interpretación de las actividades propias de las festividades de este santo patrón, me gustaría mostrar las características del arribo de la imagen de San Sebastián al municipio:

Los primeros datos de asentamientos en el municipio, provienen de "La historia de Tlaxcala" y "El memorial de los indios de Tepetlaoztoc o códice Kingsborough". En ambos documentos, se registran las peripecias que tuvieron que pasar sus habitantes desde la fundación de pequeños asentamientos durante el periodo prehispánico anterior a la formación del imperio azteca hasta la conquista y la explotación física y material que caracterizó al periodo colonial. Como lo podemos confirmar:

"Es de saber que <cuando> los chichimecas, primeros pobladores, vinieron poblando por Amaquemecan y vinieron rodeando las faldas de la Sierra Nevada y Volcán, algunos de ellos siguieron el rumbo del Norte y fueron a poblar las tierras de Tullantzinco y demás provincias de aquella sierra ...<Más> algunas cuadrillas y legiones se quedaron en la provincia de Tepetlaoztoc, que en una legua de Tetzcuco hacia la parte Norte, donde hayaron muy grandes cuevas en que vivir, y ansí se llama Tepetlaoztoc, porque quiere decir en lengua náhuatl mexicana, <<En las cuevas de la Tezca〉>. Y allí poblados, pasaron adelante sus capitanes más principales y, caminando, llegaron a la provincia de Tlaxcala" (Muñoz Camargo; 2003:123).

Pasan varias décadas y el imperio de Texcoco que recientemente se había incorporado a la Triple Alianza, comienza a exigir una muestra de tributos y lealtad absoluta a cada una de sus provincias:

“...en la época prehispánica la gente de Tepetlaoxtoc se opuso con pertinencia a los esfuerzos de los señores de Texcoco por hacer aceptar (imponer) la agricultura a los chichimecas, y prefirió conservar su actividad tradicional de cazadores-recolectores" (Pérez Lizaur; 1975:153). Paréntesis internos míos.

Se conoce por las evidencias documentales que dejaron Hernán Cortes en sus celebres "Cartas de Relación", Bernal Díaz del Castillo en "Historia verdadera de la conquista de la Nueva España" y Muñoz Camargo en "Historia de Tlaxcala", que los tlaxcaltecas apoyados por el gobierno rebelde de Texcoco, transportaron, armaron y desembotaron trece bergantines en el Lago de Texcoco, para dar inicio con la conquista militar de México-Tenochtitlan.

Solamente haré referencia a la cita más representativa del suceso:

"Después de hechos por orden de Cortés y probados en el río que llaman de Tlaxcala Zahuapan, que se atajó para probar los bergantines, los tornaron a desbaratar para llevarlos a cuestas sobre hombros de los de Tlaxcala a la ciudad de Tetzcuco, donde se echaron a la laguna, y se armaron de artillería y munición"

(Muñoz Camargo; 2003: 230). 
Para el siglo XVI, arribó la orden de los dominicos al actual municipio de Tepetlaoxtoc y comenzó la actividad económica que marcaría a la comunidad hasta sus días (Consultar: Anexo 2), como lo argumenta Pérez Lizaur:

"La tradición ganadera en Tepetlaoxtoc se remonta al siglo XVI, cuando el encomendero llevó ovejas al pueblo y ocupó las tierras de cultivo para las crías (Memorial de los indios de Tepetlaoxtoc al monarca español, Paso y Troncoso, 1912); posteriormente hubo algunas mercedes de tierra para la cría en los alrededores del pueblo (Gibson, 1967: 284). Más tarde el comercio con las recuas introdujo la tradición de cría de ganado caballar, que perdura actualmente en la charraría" (Pérez Lizaur; 1975: 159-160). "En el siglo XVII se construyó el camino real de herradura que iba de México a Veracruz y que pasa por Tepetlaoxtoc." (Pérez Lizaur; 1975: 165).

Los caminos reales del periodo colonial sirvieron como rutas comerciales entre diversos puntos del país y el centro de la nación. Tomando en cuenta la historia oral, la imagen de San Sebastián Mártir, procedente de España, arribó mediante el camino real de la herradura que inicia en el puerto de Veracruz con dirección a la ciudad de México, pero con un descanso en Tepetlaoxtoc.

A continuación, cito a Tinajero (2002), quien presenta una narración del suceso:

"Durante los siglos XVII y XVIII, Tepetlaoztoc experimentó una bonanza económica, debido a que era el paso obligado de la carretera México-Veracruz, vía CalpulalpanXalapa. La región se ligo al provechoso comercio de mulas y al establecimiento de mesones.

En el año de 1695, una recua llegó a Tepetlaoztoc procedente del puerto de Veracruz con un cargamento para la ciudad de México. Entre los objetos que transportaba traía una gran caja. Cuando los arrieros se disponían a marcharse cargaron sus mulas y continuaron su camino, pero el animal que transportaba la caja, se echó. El hombre trato de levantar la acémila, pero sin ningún éxito. Al ver que sus compañeros se alejaban pidió al mesonero le guardara su cargamento y le prometió venir a reclamarlo. Pasó el tiempo y aquel arriero nunca más se presentó. Entonces las autoridades del pueblo ... procedieron a abrir la caja en el año de 1698 y se encontraron una estatua de San Sebastián Mártir" (Tinajero; 2002: 133).

Durante la investigación, logré obtener la siguiente entrevista:

"...Venia el arriero y sus animales con cargamentos provenientes de España, y luego una de sus mulas se echó ...la golpearon, la quemaron y no lograban que se levantara. Entonces, abrieron la caja que traía y vieron que la imagen de San Sebastián. El lugar donde se echó la mula es donde está esa Cruz ${ }^{37 " ~(J o s e ́ ~ D e l g a d i l l o, ~ v e c i n o ~ d e ~}$ La Concepción Jolalpan).

"En 1698 era vicario de la doctrina de Tepetlaoztoc fray Antonio de Pastrana. El dominico procedió a construir una capilla, en honor a San Sebastián, que empezó a funcionar en 1703, pero en el transcurso de ese siglo se le enriqueció con diversos ornamentos.

\footnotetext{
${ }^{37}$ Monumento en la Calle de la Cruz, a un costado de la capilla de San Sebastián Mártir.
} 
Los gremios que existían en esa época como los arrieros, los fabricantes de cirios, los tlachiqueros, los gañanes, etc., aprovecharon la estructura que tenían para proyectarla a la organización de las fiestas de san Sebastián, a quien empezaron a considerar su patrón" (Tinajero; 2002: 134) 38

Llama la atención los orígenes de la comunidad de Tepetlaoxtoc y su relación con la imagen del santo; es decir, grupos nómadas chichimecas que se dedican a la caza y recolección, obstinados a someterse al creciente reinado de Texcoco o al imperio azteca. Y a manera de resistencia, décadas después permiten el libre tránsito de los tlaxcaltecas y los conquistadores españoles hacia el centro de Texcoco (En la actualidad es la plaza del "Portal de los bergantines") con motivos de la invasión militar de la ciudad de México-Tenochtitlan. Relacionándolo con el mito de la llegada de la imagen de San Sebastián; es decir, un arriero (nómada) que viaja desde el puerto de Veracruz hacia la ciudad de México por un camino real de origen colonial, que abandonó su mercancía en el pueblo de Tepetlaoxtoc porque la mula no se volvió a incorporar. Y años después cuando se abrió el paquete, surge la imagen de un santo católico que fue martirizado con disparos de arqueros y lanceros romanos. Tomando en consideración que en las creencias católicas mesoamericanas, se argumenta que las imágenes de los santos patrones aumentan su peso hasta el grado que ya no pueden ser levantadas del suelo, por lo que se termina abandonando a la figura en ese sitio y posteriormente se edifica una capilla en su honor; es decir, la creencia dicta que la imagen del santo eligió el sitio donde se le construirá su templo, la población que protegerá y le rendirá culto, so pena de tener un castigo divino de carácter individual o colectivo. Es como lo sostienen la mayoría de los tepetlaoxtoqueños católicos en la actualidad. Tras esa vía, presento las siguientes interrogantes: ¿Qué características tienen las mayordomías de San Sebastián?, ¿Cómo funcionan los espacios de interacción en el calendario de estas mayordomías?

\footnotetext{
${ }^{38}$ Subrayado mío.
} 


\subsection{LAS MAYORDOMÍAS DE SAN SEBASTIÁN.}

Presento un poema inspirado en la fiesta de San Sebastián Mártir y otro que recuerda tanto los festejos de Santa María Magdalena como las fiestas patronales que se realizan por cada uno de los barrios del centro de Tepetlaoxtoc.

\begin{tabular}{|c|c|}
\hline $\begin{array}{c}\text { El } 20 \text { de enero en este mi pueblo } \\
\text { Bello } \\
\text { Son } 11 \text { Mayordomías, todas ellas } \\
\text { concurridas, llenas de Fuegos } \\
\text { Artificiales, Peregrinos, Bailadores y sus } \\
\text { Comidas. } \\
\text { Los Mexicanos, los de San Pedro. } \\
\text { El } 20 \text { y el Primer Domingo } \\
\text { Son fiestas verdaderas. } \\
\text { Los Cirios, Albañiles, Comerciantes } \\
\text { Y molenderas nos dejan recuerdos } \\
\text { Sinceros, así como los gañanes y } \\
\text { Tlachiqueros culminan esta hermosa } \\
\text { Fiesta con el simulacro de los arrieros. }\end{array}$ & $\begin{array}{c}\text { Que lindo es Tepetlaoxtoc con sus } \\
7 \text { iglesias a la buena } \\
\text { Y en cada Fiesta de sus Barrios, una } \\
\text { noche de verbena. } \\
\text { Pero también celebramos aquí a } \\
\text { Santa María Magdalena. }\end{array}$ \\
\hline
\end{tabular}

Ambos versos son el resultado de la inspiración de Don Armando Alsivar, oriundo y vecino del barrio del Calvario en Tepetlaoxtoc centro.

Las diez mayordomías con sus respectivos festejos que se realizan en honor a San Sebastián, tienen las siguientes características generales:

1) Para los habitantes de Tepetlaoxtoc, el festejo de la mayordomía del 20 de enero (día de San Sebastián Mártir) se realiza sin importar el día de la semana que corresponda al calendario vigente. Por otra parte, las nueve mayordomías satelitales que se realizan días antes y después en honor a su santo patrón, no se efectúan en una fecha específica. Y sus creyentes no ven como una obligación el hecho de asistir a esos festejos en comparación con la mayordomía del 20 de enero, fecha que es un requisito el visitar al santo. Incluso en varias ocasiones, las personas que entrevistaba me comentaban que ellos y sus familiares procuraban participar o asistir lo menos posible en los festejos de las mayordomías satelitales, por el número de ebrios que rondaban la vía pública en esos días.

A continuación presento el orden del ciclo festivo del año 2009:

La celebración a San Sebastián Mártir comenzó el domingo 18 de enero con la ceremonia de la mayordomía de los mexicanos, que finalizó con un baile gratuito en las canchas de futbol. El lunes 19 arribó la peregrinación de San Pedro Chiautzingo (pueblo 
que pertenece al municipio) representada por la mayordomía del 19 de enero; el martes 20 se realizó la fiesta grande personificada por la mayordomía del 20 de enero. Durante los días miércoles 21 , jueves 22 y viernes 23 de enero no hubo ninguna actividad extraordinaria en el pueblo, porque por costumbre no está permitido retomar los festejos antes del primer sábado posterior al día 20. En tanto el sábado 24 y el domingo 25 de enero, se presentaron las danzas regionales de las sembradoras, los vaqueros y sembradores, quienes se dividen simbólicamente el día en tres partes para otorgar su espectáculo al santo patrón y a los asistentes desde la mañana hasta altas horas de la noche en la Calle de la Cruz. Cabe mencionar que el domingo 25 de enero, se presentó el jaripeo-baile en el barrio del Calvario, Tepetlaoxtoc centro, pero también se celebraba a San Pablo Apóstol, en el barrio de San Pablo del pueblo de Jolalpan, Tepetlaoxtoc. Los festejos de este último solamente duraron tres días.

El lunes 26 de enero, se exhibió la mayordomía de los cirios, seguida por las molenderas, el miércoles 28 hicieron su aparición los gañanes y el jueves 29 se efectuó la fiesta de los tlachiqueros. El viernes 30 de enero fue la mayordomía de los comerciantes, después la mayordomía de los albañiles, y el día 1 de febrero tuvo lugar la mayordomía de los arrieros. Al día siguiente (2 de febrero), se celebró a la Virgen de la Candelaria en el barrio del mismo nombre que pertenece al pueblo de Jolalpan.

En el siguiente apartado, serán descritas y analizadas todas y cada una de las fiestas que se realizaron en honor a San Sebastián. Por el momento describo el ciclo festivo de la mayordomía del 20 de enero, pero que se celebrará en el año 2012 como una forma de cuestionar la movilidad de las demás mayordomías satelitales que acompañan su festejo ${ }^{39}$ : La mayordomía de los mexicanos será celebrada el domingo 15 de enero del año 2012, durante los siguientes tres días; es decir, lunes 16, martes 17 y miércoles 18. No habrá ninguna actividad extraordinaria en el pueblo más que la presencia de la feria y sus juegos mecánicos; también estarán algunos puestos de cerveza ofreciendo sus servicios, juegos de azar y antojitos mexicanos, pero el día jueves 19 de enero será recibida la mayordomía del mismo nombre. Al día siguiente se realizará la fiesta grande en honor a San Sebastián Mártir, el sábado 21 y domingo 22 se presentarán las danzas regionales y el lunes 23 y siguientes participará la mayordomía de los cirios, las molenderas, los gañanes. El jueves 26 se presentará la mayordomía de los tlachiqueros y los días siguientes se presentan la

\footnotetext{
${ }^{39}$ La aproximación de los festejos del mes de enero del año 2012, fue elaborada por el Sr. Víctor Varela que es vecino de Tepetlaoxtoc centro y el antropólogo Roberto Rivera. Enero 2009.
} 
mayordomía de los comerciantes, los albañiles y para cerrar la fiesta, se exhibirá la mayordomía de los arrieros el día domingo 29 enero del año 2012.

Se evidencia que para los habitantes de Tepetlaoxtoc existen dos tipos de tiempos al año, el primero es el festivo acorde a las prescripciones y puntos calendáricos católicos, y el segundo es el ordinario o dedicado a las labores cotidianas. En este sentido, el tiempo festivo se puede dividir en dos categorías más, por lo menos en el caso de las celebraciones propias al mes de enero. La primera, se refiere a los cultos que se realizan en una fecha preestablecida, pero sin importar el día de la semana. Tal es el caso de las mayordomías del 19 y 20 de enero. Y las segundas, son las conmemoraciones que se efectúan en un día a la semana específico, sin importar la fecha que corresponda, pero que está supeditada a otra celebración. Por ejemplo:

La norma cultural establece que el último domingo antes del 20 de enero sin importar el día que corresponda al calendario, será presentada la mayordomía de los mexicanos. Lo mismo ocurre el primer lunes después del 20 de enero, pues, hacen su aparición la mayordomía de los cirios, y para el primer jueves después de la fiesta grande le corresponde a la mayordomía de tlachiqueros. Por último, el segundo domingo después de la fiesta grande 0 el primero después de la mayordomía de los cirios y para concluir la fiesta, se presenta la cuadrilla de los arrieros con su representación de los bandidos de Río Frío.

2) Pueden prestar sus servicios en cualquiera de las nueve mayordomías, varones que estén casados, solteros, en unión consuetudinaria mesoamericana, divorciados, separados y viudos, con la condición que sean mayores de edad y tengan un empleo 0 trabajo temporal. En el caso de la fiesta de las molenderas, todos los puestos de mayordomos serán ocupados exclusivamente por mujeres solteras (señoritas casaderas de quince años o más), casadas y abuelas. Cabe aclarar, que con excepción de la mayordomía de las molenderas:

“...La mayordomía está abierta a cualquier solicitante"

(Entrevista con el Sr. Víctor Manuel Varela, habitante del barrio de la Columna, Tepetlaoxtoc centro).

3) El festejo de cada mayordomía dura 24 horas, comenzando después de las doce de la noche 0 en el momento que se acabó de encender el último fuego pirotécnico del castillo de la mayordomía saliente. 
4) Cada mayordomía durante el transcurso de su celebración (24 horas), tiene que encontrar su remplazo para el año siguiente. La manera de encontrarlos es tocar directamente en la puerta del solar de los candidatos, mismos que los mayordomos salientes han estado observado durante un año. Sí la puerta del solar se abre, inmediatamente se le otorga un vaso con tequila al varón que abrió a manera de simbolizar y enfatizar que aceptó el cargo. A continuación la banda de viento (clásica) toca un son local y se continúa con la búsqueda. En caso de que no se abra la puerta, se procede a seguir buscando el reemplazo en otros solares del barrio.

5) Se tienen que encontrar a los voluntarios que deseen recibir en su casa al santo y ofrecer un desayuno, comida o cena a los mayordomos e integrantes de los grupos de danza regionales, como son: las dancitas y sembradoras, los sembradores, vaqueros, serranos y segadores.

6) Todas las mayordomías satelitales y la grande (la del 20 de enero) tienen que contratar un mariachi o banda clásica para ofrecer las mañanitas al santo patrón el día que corresponde a su participación, pagan el estipendio de la eucaristía en la que se menciona el nombre de la mayordomía, su respectivo rosario, contratar un grupo musical y / o animadores para los festejos de la noche, comprar un castillo de fuegos pirotécnicos, bombas y cohetes, presentar si la mayordomía lo requiere, un simulacro de sus actividades laborales y / 0 un grupo de danzas regionales. La excepción es la peregrinación de San Pedro Chiautzingo, quienes solamente entregan regalos al santo. Cabe mencionar, que también se presenta un jaripeo portátil, armado y realizado en algún terreno que sea prestado para el efecto.

7) Las personas que deseen participan de las distintas mayordomías en Tepetlaoxtoc, comienzan a arribar a partir de las dos de la tarde, horario que es más evidente la venta de antojitos mexicanos y bebidas alcohólicas. Excepto en la fiesta grande, el primer fin de semana y en las mayordomías satelitales de los tlachiqueros y arrieros, pues en estos casos se comienza desde más temprano según sea el caso.

8) Existen ocasiones en que algunos visitantes que pueden o no compartir algún tipo de lazo de parentesco o parentesco ritual con algún habitante de los distintos pueblos de Tepetlaoxtoc, solicitan a los mayordomos en turno (cualquier mayordomía) que la 
imagen del santo visite su casa. Como ha sido el caso de algunos vecinos de los estados de Morelos, Puebla, Querétaro, Veracruz, Estado de México (municipios de Texcoco, Chiconcuac y Nezahualcóyotl) o alguna delegación del Distrito Federal, quienes han recibido la imagen del santo. Tiempo después de la solicitud y en una fecha convenida, parta una procesión de mayordomos, vecinos del municipio de Tepetlaoxtoc y una banda clásica hasta la casa del solicitante, y este, los recibe con bebidas alcohólicas y abundante comida. El hecho provoca que tanto los mayordomos como el solicitante se conviertan en compadres de imagen, dando inicio a sus propias redes de parentesco ritual. Las ventajas inmediatas de este compadrazgo, es que por ambas partes se podrá contar con un sitio en donde se pueda comer, beber y quizá dormir de manera gratuita durante los festejos de San Sebastián en Tepetlaoxtoc 0 en las solemnidades del santo patrón de la comunidad en donde se recibió la imagen.

Tabla 1.

\begin{tabular}{|c|c|c|c|}
\hline 6 de enero & $\begin{array}{l}\text { Los Santos Reyes, barrio } \\
\text { de Nopala. }\end{array}$ & 15 de mayo & $\begin{array}{l}\text { San Isidro Labrador, colonia La } \\
\text { Loma y gremio de los Gañanes, } \\
\text { Tepetlaoxtoc centro. }\end{array}$ \\
\hline $\begin{array}{l}\text { Último } \\
\text { domingo antes } \\
\text { del } 20 \text { de } \\
\text { enero }\end{array}$ & $\begin{array}{lr}\text { Mayordomía } & \text { de los } \\
\text { mexicanos, } & \text { Tepetlaoxtoc } \\
\text { centro. } & \end{array}$ & Mayo o junio & $\begin{array}{l}\text { La Santísima Trinidad, barrio de } \\
\text { la Trinidad, Tepetlaoxtoc centro. }\end{array}$ \\
\hline 19 de enero & $\begin{array}{l}\text { Mayordomía del } 19 \text { de } \\
\text { enero o peregrinación de } \\
\text { San Pedro Chiautzingo, } \\
\text { Tepetlaoxtoc centro. }\end{array}$ & 24 de junio & $\begin{array}{l}\text { San Juan Bautista, pueblo de } \\
\text { Totolapan. }\end{array}$ \\
\hline 20 de enero & $\begin{array}{l}\text { San Sebastian Mártir, } \\
\text { Tepetlaoxtoc centro. }\end{array}$ & 29 de junio & $\begin{array}{l}\text { San Pedro y San Pablo, pueblo } \\
\text { de San Pedro Chiautzingo. }\end{array}$ \\
\hline $\begin{array}{l}\text { Primer sábado } \\
\text { y domingo } \\
\text { posterior al } 20 \\
\text { de enero }\end{array}$ & $\begin{array}{l}\text { Danzas regionales de los } \\
\text { sembradores, vaqueros, } \\
\text { las dancitas y sembradoras, } \\
\text { Tepetlaoxtoc centro. }\end{array}$ & 22 de julio & $\begin{array}{l}\text { Santa María Magdalena, } \\
\text { parroquia de Tepetlaoxtoc. }\end{array}$ \\
\hline $\begin{array}{l}\text { Primer lunes } \\
\text { después del } \\
20 \text { de enero }\end{array}$ & $\begin{array}{l}\text { Mayordomía de los cirios, } \\
\text { Tepetlaoxtoc centro. }\end{array}$ & 23 de julio & $\begin{array}{l}\text { Continuación de la fiesta de } \\
\text { Santa María Magdalena. }\end{array}$ \\
\hline $\begin{array}{l}\text { Primer martes } \\
\text { después del } \\
20 \text { de enero }\end{array}$ & $\begin{array}{l}\text { Mayordomía } \text { de las } \\
\text { molenderas, Tepetlaoxtoc } \\
\text { centro. }\end{array}$ & 24 de julio & $\begin{array}{l}\text { Continuación de la fiesta de } \\
\text { Santa María Magdalena. }\end{array}$ \\
\hline $\begin{array}{l}\text { Primer } \\
\text { miércoles } \\
\text { después del } \\
20 \text { de enero }\end{array}$ & $\begin{array}{lr}\text { Mayordomía } & \text { de } \quad \text { los } \\
\text { gañanes, } & \text { Tepetlaoxtoc } \\
\text { centro. } & \end{array}$ & 25 de julio & $\begin{array}{l}\text { Santiago Apóstol, Colonia } \\
\text { Santiago. }\end{array}$ \\
\hline $\begin{array}{l}\text { Primer jueves } \\
\text { después del } \\
20 \text { de enero }\end{array}$ & $\begin{array}{l}\text { Mayordomía de los } \\
\text { tlachiqueros, Tepetlaoxtoc } \\
\text { centro. }\end{array}$ & 26 de julio & Santa Ana, Barrio de Jolalpan. \\
\hline
\end{tabular}




\begin{tabular}{|c|c|c|c|}
\hline $\begin{array}{l}\text { Primer viernes } \\
\text { después del } \\
20 \text { de enero }\end{array}$ & $\begin{array}{l}\text { Mayordomía } \quad \text { de } \quad \text { los } \\
\text { comerciantes, } \\
\text { centro. }\end{array}$ & 15 de agosto & $\begin{array}{l}\text { Santa María Asunción, Barrio } \\
\text { de Tepetlaoxtoc centro. }\end{array}$ \\
\hline $\begin{array}{l}\text { Primer sábado } \\
\text { después del } \\
20 \text { de enero }\end{array}$ & $\begin{array}{lrr}\text { Mayordomía } & \text { de los } \\
\text { albañiles, } & \text { Tepetlaoxtoc } \\
\text { centro. } & \end{array}$ & 20 de agosto & $\begin{array}{l}\text { San Bernardo, parroquia del } \\
\text { pueblo de Tlalmimilolpan. }\end{array}$ \\
\hline $\begin{array}{l}\text { Segundo } \\
\text { domingo } \\
\text { después del } \\
20 \text { de enero }\end{array}$ & $\begin{array}{l}\text { Mayordomía de los arrieros, } \\
\text { simulacro de los "Bandidos } \\
\text { de Río Frío" y danza } \\
\text { regional de los serranos. }\end{array}$ & 8 de septiembre & $\begin{array}{l}\text { Señora de Loreto pueblo de } \\
\text { Tulteca Teopan. }\end{array}$ \\
\hline 25 de enero & $\begin{array}{l}\text { San Pablo Apóstol, barrio } \\
\text { de Jolalpan. }\end{array}$ & 21 de septiembre & $\begin{array}{l}\text { San Mateo Colonia } \\
\text { Tulteca Teopan. }\end{array}$ \\
\hline 2 de febrero & $\begin{array}{l}\text { Santa María Candelaria, } \\
\text { barrio de Jolalpan. }\end{array}$ & 22 de septiembre & $\begin{array}{l}\text { Santo Tomás de Villanueva, } \\
\text { pueblo de Apipilhuasco. }\end{array}$ \\
\hline $\begin{array}{l}\text { Febrero } \\
\text { o marzo }\end{array}$ & $\begin{array}{l}\text { Martes de carnaval, barrio } \\
\text { de San Francisco en } \\
\text { Jolalpan. }\end{array}$ & 29 de septiembre & $\begin{array}{l}\text { San Miguel Arcángel, pueblo de } \\
\text { San Pedro Chiautzingo. }\end{array}$ \\
\hline 7 de marzo & $\begin{array}{l}\text { Santo Tomás de Aquino, } \\
\text { pueblo de Apipilhuasco. }\end{array}$ & 4 de octubre & $\begin{array}{l}\text { San Francisco de Asís, Barrio } \\
\text { de Jolalpan }\end{array}$ \\
\hline 19 de marzo & $\begin{array}{l}\text { San José, Parroquia de } \\
\text { Tepetlaoxtoc centro. }\end{array}$ & 1 de noviembre & $\begin{array}{l}\text { Día de muertos, todo el } \\
\text { municipio }\end{array}$ \\
\hline $\begin{array}{l}\text { Marzo (tercer } \\
\text { viernes de } \\
\text { cuaresma) }\end{array}$ & $\begin{array}{l}\text { Señor de la Columna, } \\
\text { barrio de Tepetlaoxtoc }\end{array}$ & 2 de noviembre & $\begin{array}{l}\text { Día de muertos, todo el } \\
\text { municipio }\end{array}$ \\
\hline 5 de abril & $\begin{array}{l}\text { San Vicente Ferrer, barrio } \\
\text { de Tepetlaoxtoc, centro. }\end{array}$ & 25 de noviembre & $\begin{array}{l}\text { Santa Catalina, pueblo de San } \\
\text { Bernardo Tlalmimilolpan. }\end{array}$ \\
\hline Marzo o abril & $\begin{array}{l}\text { Semana Santa, todo el } \\
\text { municipio. }\end{array}$ & 30 de noviembre & $\begin{array}{l}\text { San Andrés, pueblo de San } \\
\text { Andrés de las Peras. }\end{array}$ \\
\hline Marzo o abril & $\begin{array}{l}\text { Domingo de Pascua de } \\
\text { Resurrección, pueblo de } \\
\text { San } \\
\text { Tlalmimilolpan. }\end{array}$ & 8 de diciembre & $\begin{array}{l}\text { La Purísima Concepción, barrio } \\
\text { de Jolalpan. }\end{array}$ \\
\hline 29 de abril & $\begin{array}{l}\text { San Pedro Verona, San } \\
\text { Pedro Chiautzingo. }\end{array}$ & 12 de diciembre & $\begin{array}{l}\text { Santa María de Guadalupe, } \\
\text { todo el municipio. }\end{array}$ \\
\hline 3 de mayo & $\begin{array}{l}\text { La santa cruz, todo el } \\
\text { municipio }\end{array}$ & 22 de diciembre & $\begin{array}{l}\text { Santo Tomas, pueblo de } \\
\text { Apipilhuasco. }\end{array}$ \\
\hline
\end{tabular}

Ciclo festivo del municipio de Tepetlaoxtoc.

Inspirado en la monografía municipal de Cando Morales (1999) 


\subsection{LAS MAYORDOMÍAS Y SUS ESPACIOS DE INTERACCIÓN. \\ Mayordomía de los mexicanos.}

Debido a que la mayoría de las tierras que pertenecen al municipio de Tepetlaoxtoc no son aptas para el cultivo agrícola, se observa un auge en la cría de ganado vacuno, bovino, caprino y caballar en la década de los 20's a los 40’s. Para las personas que no tenían los recursos económicos para adquirir animales o competir contra los ranchos de la zona, como son: Buenavista Guadalupe, Cayon, las Cuevas, la Arboleda, Potrillo, Centeno y Tezoquipa la Virgen o la hacienda de la Flor, optaron por la emigración laboral al Distrito Federal 0 algún otro estado de la república. Recién, hay una migración hacia los Estados Unidos y Canadá. En la actualidad, se pueden ver anuncios de venta de terrenos que van desde $500 \mathrm{~m} 2$ hasta cinco hectáreas; también se venden casas, casonas, quintas y casas con terreno. Lo que invita a especular sobre la cantidad de emigración nacional o migración internacional propia de la zona.

En el mes de enero del año de 1930, se celebró la primera mayordomía de los mexicanos. Y su nombre se debe a que:

"... aquí (en Tepetlaoxtoc) les llamamos mexicanos a todos aquellos habitantes que se fueron a vivir a México, así le decimos al Distrito Federal" (Entrevista con Don Armando Alsivar) ${ }^{40}$.

Esta mayordomía se forma de personas oriundas (principalmente al centro de Tepetlaoxtoc), que por razones laborales radican de forma temporal o definitiva en alguna delegación del Distrito Federal. Lo que implica que tienen que utilizar las redes sociales y familiares para saber exactamente qué familiar, de qué familia y en dónde se le puede localizar a esa persona para que apoye a la mayordomía de ese año o sea el remplazo para el siguiente. Según se me comentó, solamente arriban a Tepetlaoxtoc dos o tres representantes de esta mayordomía días antes de la fiesta, para solicitar el permiso a las autoridades civiles, al cuerpo de policía local y acordar con el presbítero el horario de la eucaristía, pues todos los preparativos se realizan desde el Distrito Federal.

A lo más dos días antes del último domingo antes del 20 de enero, comienzan a llegar los puestos de cerveza, antojitos mexicanos, panes de Tlaxcala y el toro mecánico en las calles de Tlacaluca y Ocoyococ. Así como los primeros juegos mecánicos de la feria temporal en la Plaza Hidalgo.

Una vez que llegó el día, a las cinco de la mañana el grupo de mariachis toca las mañanitas a San Sebastián, inmediatamente después se arrojan unos cohetes y las campanas comienzan a tocar. A medio día, se realizan los rezos o rosarios a favor a la mayordomía y las actividades se

\footnotetext{
${ }^{40}$ Paréntesis mío.
} 
paran hasta las diez de la noche, horario en que inició el baile gratuito en las canchas de futbol. Durante las horas que fueron intermedias, los visitantes, turistas y habitantes (oriundos y emigrantes) disfrutan de la transformación temporal del paisaje (terrenos de siembra que se habilitan como estacionamiento público, servicios de sanitarios públicos dentro de las casas particulares, uso peatonal de las principales calles del centro del municipio) y los primeros servicios temporales (puestos de bebidas embriagantes, comida, antojitos, juegos de azar, etc.) que se instalan de manera definitiva por los próximos 15 días.

\section{La mayordomía del 19 de enero o la peregrinación de San Pedro.}

Esta ritualidad es realizada por los mayordomos del pueblo vecino de San Pedro Chiautzingo perteneciente al mismo municipio. En la actualidad, no existe un consenso sobre la fecha exacta en que se realizó por primera vez la peregrinación, pues los datos remiten desde los primeros años del siglo XX hasta la década de los 20's ó 30's. La historia oral sí afirma que la primera peregrinación realizada, fue con la intención de combatir una epidemia que se desató en ese pueblo. Al respecto presento el siguiente comentario:

"Después de que inició la epidemia de ronchas, donde todos se enroncharon. Sus habitantes decidieron y bajaron a la fiesta de San Sebastián, y por arte de magia se limpiaron en esa primera ocasión. Después bajaban durante varios años hasta que en un año retiraron la procesión, y al año siguiente nuevamente no asistieron. Entonces, volvió otra epidemia pasando la festividad (de San Sebastián Mártir). La epidemia llegó por falta de cumplimiento al santo. En una fecha posterior, volvieron para cumplir la promesa, provocando que la epidemia cesara volviéndose a limpiar. Entonces jamás se ha vuelto a ver al pueblo (Chiautzingo) envuelto en epidemia, cumpliendo año con año su promesa" (Entrevista con Don Armando Alsivar, habitante del barrio del Calvario, Tepetlaoxtoc centro) ${ }^{41}$

En base a la cercanía geográfica que existe entre la comunidad de San Pedro Chiautzingo y el centro de Tepetlaoxtoc (Ver mapa 2), la comitiva de Chiautzingo parte a lo más una hora y media antes de las 7:30 u 8:00 p. m., horario en que los visitantes, oriundos y turistas se comienzan a acomodar en la calle de Tlacaluca (ver mapa 1) o en los puestos de cerveza que se instalan en esa misma calle. La procesión es encabezada por un grupo de coheteros, quienes van anunciando mediante las explosiones la distancia que existe entre la comitiva y su destino. Inmediatamente le siguen los estandartes de San Sebastián Mártir y después de San Pedro, seguido de una imagen de ambos santos, algunos vecinos de Chiautzingo acompañan la procesión, de los cuales las mujeres son las únicas que cargan velones encendidos. Al final de la comitiva se puede vislumbrar la banda clásica que va tocando música de fiesta de pueblo.

\footnotetext{
${ }^{41}$ Paréntesis internos míos.
} 
Mapa 2

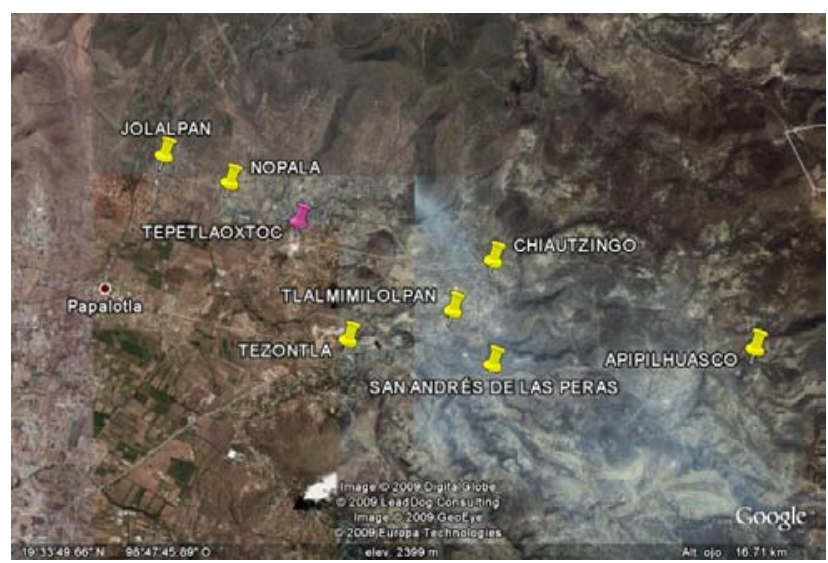

Los pueblos del municipio de Tepetlaoxtoc.

La procesión pasa por las calles de Tlacaluca y Ocoyococ, sin importar que en estas estén instalados los negocios temporales propios de la fiesta, por ende, hay una gran cantidad de concurrencia. La procesión sigue su camino hasta llegar al "atrio" de San Sebastián que está en la plaza del mismo nombre. Inmediatamente después de la entrada de la comitiva en el templo, el presbítero realiza una celebración de palabra; es decir, desarrolla todos los puntos del esquema de la eucaristía, pero no realiza la consagración. En las peticiones se pide por que San Sebastian bendiga a las comunidades de Tepetlaoxtoc y Chiautzingo, pero en especial se pide por los mayordomos encargados de este festejo. Debo argumentar, que el motivo por el cual la procesión de Chiautzingo utiliza las calles más concurridas y la ruta más larga (del territorio festivo) para arribar a la capilla de San Sebastián, se debe a que:

"...en esos universos sociales y mentales, los seres humanos que donan más de lo que se les ha donado, o que donan tal cantidad que nadie podrá jamás realizar un contradon equivalente, se eleva por encima de los restantes hombres y son un poco como los dioses, o cuando menos se les parecen" (Godelier; 1998: 51).

Por ende, se explica el hecho de elegir la ruta más larga y concurrida, pues estos mayordomos buscan ser vistos y reconocidos socialmente por algún vecino, conocido, amigo, familiar 0 pariente ritual que los reconozcan a ellos y admiren su participación en el orden del cosmos; es decir, evitar otra epidemia en su pueblo. Además, se espera lograr el favor del santo al entregarle parte de lo que supuestamente creó en una deuda eterna entre los hombres y los dioses. Pues retomo de Godelier (1998):

"...los dioses son libres de donar o no, y que los hombres abordan a los dioses a partir de una deuda previa, pues de ellos han recibido todas las condiciones de existencia" (Godelier; 1998:51). 
Una vez que se finalizó con la celebración de palabra, los festejos se extienden hasta altas horas de la noche, pero en los establecimientos fijos (pulquería, cantinas y tiendas de abarrotes) o en los negocios temporales que se instalaron, porque esta mayordomía no realiza ningún baile 0 alguna otra actividad de esparcimiento.

Muchos de los oriundos del centro de Tepetlaoxtoc, vecinos de algún pueblo del municipio o en particular los habitantes de Chiautzingo que llegaron antes de la procesión, se dirigen a la capilla de San Sebastián con la intención de persignarse, ya sea desde el umbral del templo, dentro de la capilla 0 a pocos centímetros de la imagen, como solicitando la autorización del santo para gozar libremente de su fiesta o embriagarse sin ningún castigo divino. Otros feligreses, simplemente esperan la celebración de la palabra para después incorporarse a los festejos, como dice Geertz (1987):

“...lo que los símbolos sagrados dramatizan no son solamente valores positivos, también dramatizan valores negativos. Dichos símbolos apuntan no sólo a la existencia del bien sino también hacia la del mal y hacia el conflicto entre ambos. El llamado problema del mal consiste en formular desde el punto de vista de la cosmovisión la verdadera naturaleza de las fuerzas destructivas que moran en la persona y fuera de él, en interpretar los homicidios, los fracasos en las cosechas, la enfermedad, los terremotos, la pobreza y la opresión de manera tal que sea fundamentalmente irreal -como ocurre ...en algunas versiones del cristianismo- es sólo una solución del problema más bien infrecuente; con mayor frecuencia se acepta la realidad del mal y se la caracteriza; y cierta actitud frente al mal -resignación, oposición activa, evasión hedonista, recriminación a uno mismo y arrepentimiento o humildes súplicas para obtener misericordia- es considerada razonable y apropiada dada su naturaleza" (Geertz; 1987: 121).

Cabe mencionar, que la imagen de San Sebastián Mártir no visita a San Pedro Chiautzingo en su celebración; es decir, el día 29 de junio. El día que también se festeja a San Pablo Apóstol en este pueblo del Acolhuacán Septentrional. Se puede formular la siguiente pregunta: ¿Existirá una tendencia a la circulación de agentes matrimoniales entre estas dos comunidades con el pretexto de la festividad de sus santos? Se tiene que recordar que la teoría antropológica, en particular el estructuralismo francés ha argumentado que los grupos que tienden a mantener prestaciones y contraprestaciones de carácter económico, social y ceremonial; complementan su reciprocidad, con el intercambio de mujeres entre sus respectivos grupos ${ }^{42}$. Por ende, muy probablemente exista una tendencia matrimonial observable entre estas comunidades, que las diferencie en su relación con otras, a pesar de compartir el mismo entorno. Y a pesar de que en

\footnotetext{
42 “...las mitades están unidas una con otra, no sólo por el intercambio de mujeres sino por el abastecimiento de prestaciones y contraprestaciones recíprocas de carácter económico, social y ceremonial ...el sistema dualista no da nacimiento a la reciprocidad: sólo constituye su puesta en forma. Esta puesta en forma pudo ser a veces el objeto de un descubrimiento local, impuesto más tarde por la conquista o copiado a causa de su comodidad”

(LÉVI-STRAUSS; 1985: 109).
} 
las genealogías levantadas no se registró ningún matrimonio entre vecinos de Tepetlaoxtoc y / 0 con Chiautzingo no se puede descartar la posibilidad.

\section{La mayordomía del 20 de enero.}

La mayordomía del 20 de enero, se encarga desde altas horas de la madrugada de ofrecer las mañanitas a San Sebastián Mártir, el templo comienza a lucir los distintos arreglos florales que se colocaron desde el día anterior 0 antes de las mañanitas. Los cohetes y las bombas suenan con más frecuencia a comparación de los días anteriores y superarán por mucho a los días siguientes. Por último, desde las doce de la noche comienza el rodeo que finaliza hasta las cinco o seis de la mañana de este día.

Desde muy temprano en la Calle de la Cruz, se vislumbra que se colocarán dos escenarios (uno donde comienza la calle y otro en donde finaliza). En la plaza San Sebastián, se presentó el grupo de las dancitas como la primera danza regional.

Desde sus hogares muchos de los habitantes de los diversos pueblos del municipio, se comienzan a hacer de la idea de que no asistirán a su trabajo sólo por este día, que cubrirán medio tiempo o que simplemente cumplirán, pero de todas formas, se visten con ropa tipo vaquera (sombrero -de marca Resistol o Tardan cuando existen los medios económicos-, camisa a cuadros o rayada, chamarra de piel (tipo marlboro), mezclilla o sintética, cinturón vaquero o charro, pantalón vaquero de mezclilla marca Wrangler y botas -de piel exótica de ser posible $)^{43}$.

En el transcurso del día se celebra la eucaristía, las amas de casas prepararon con anticipación la comida de fiesta que darán a sus amigos, parientes rituales y familiares que hayan invitado a comer y beber en su hogar. $Y$ varios hombres se dedican a beber desde antes del medio día hasta quedarse dormidos en alguna banqueta o hasta finalizar el festejo en la madrugada.

Las cantinas, tiendas, la pulquería y los negocios temporales de cerveza ofrecen todo tipo de bebidas embriagantes en diversas presentaciones y costos, así como la venta de vasos y refrescos. Los juegos mecánicos que están frente a la plaza Hidalgo, ofrecen sus servicios a los infantes que van acompañados de sus padres o parientes (principalmente abuelos). Esta plaza en particular, fue uno de los pocos espacios sociópetos que descubrí, pues con el pretexto de llevar a los hijos o nietos a los juegos mecánicos, permitía la interacción entre amigos, parientes y compadres que se encontraban fortuitamente en el mismo espacio y que llegaron por el mismo pretexto. La ocasión ameritaba una plática, presentar a los acompañantes, actualizar los datos

\footnotetext{
${ }^{43}$ Durante todos los festejos observé personas vestidas de vaqueros o con parte de la indumentaria, pero en este día, lo extraño era no estar vestido así.
} 
con respecto a ambas familias y la invitación a comer en la casa de alguno de los interactuantes en alguna otra ocasión. Otro de los espacios sociópetos que logré identificar eran los puestos de comida que también se abarrotan en este día, y que obligaban a invitarle algo de comer a los transeúntes conocidos, sólo si se detenían a platicar o eran llamados a acompañarlos en la mesa que se ocupaba.

Por último, durante la mayoría de las fiestas se transformaba temporalmente el espacio aledaño a la capilla; es decir, algunas calles obscuras que están cercanas al centro o la capilla de San Sebastián se habilitan como baños públicos, terrenos de siembra como estacionamientos, habitaciones desocupadas de algún solar como guardarropa y el garaje para vender hamburguesas, hot dogs y también micheladas.

A las nueve 0 diez de la noche se realiza la serenata 44 para el santo patrón en la Calle de la Cruz, la cual consiste en la presentación de varios grupos norteños, de banda y comediantes que amenizan hasta altas horas de la noche, lo que la convierte en un baile público de carácter gratuito a lo largo de la calle. Este fenómeno que se presentó desde la mayordomía de los mexicanos, se puede cuestionar: ¿Qué restricciones o problemas pueden aparecer durante los bailes vistos como contexto de interacción?

\section{-Los bailes populares-}

Uno de los espacios de interacción socialmente más aceptado en la mayor parte de la república mexicana, incluyendo tanto los pueblos tradicionalistas como los que se están insertando más rápidamente a la modernidad y globalización, son los bailes populares de carácter público (gratuito) y los semiprivados. Con respecto a los primeros, se realizan en espacios que son temporalmente adecuados para el efecto, como pueden ser jardines municipales, canchas deportivas (futbol o basquetbol), explanadas públicas, terrenos de cultivo, calles, etc. Y se efectúan en honor a un santo patrón de barrio o pueblo en el contexto mesoamericano. 0 también en razón a un festejo patriótico nacional, como es el 16 de septiembre.

En cambio los bailes semiprivados, adquieren su perfil pues se requiere cubrir el costo de las localidades para poder ingresar a ellos. Estos bailes surgen gracias a capitales privados quienes se encargan de promocionar el evento, contratar a los artistas, cobrar las entradas y recuperar la inversión con ganancias; en otras palabras, es toda una industria cultural con fuertes vínculos con los consorcios mediáticos.

Debido a las características de los bailes semiprivados éstos se tienen que realizar en instalaciones especiales como pueden ser: auditorios al aire libre, salones o clubes de baile,

\footnotetext{
${ }^{44}$ Término local.
} 
bodegas industriales, la tradicional Feria del Caballo en Texcoco y en la explanada del municipio o las canchas deportivas de la localidad, pero debidamente cercadas para evitar que se brinquen los transeúntes que deseen inevitablemente incluirse en el evento sin pagar.

Los bailes que se realizaron durante la mayordomía de los mexicanos, en la serenata de la mayordomía del 20 de enero del 2009, en los tlachiqueros, comerciantes y en los barrios de San Pablo o la Candelaria del pueblo de Jolalpan, tuvieron un carácter de públicos. Los asistentes comenzaron a llegar desde las nueve o diez de la noche, pero en todos los casos con excepción de la mayordomía de los tlachiqueros -como se verá más adelante-, observé las siguientes costumbres:

Las señoritas en edad casadera arribaban al baile de las siguientes formas:

a) Con sus padres y familiares cercanos, es decir, primos y tíos.

b) En grupos de tres a cinco señoritas, pero acompañadas de un varón que era el novio de alguna de ellas. Esta forma de llegar es la más recurrente en los bailes de Tepetlaoxtoc.

c) Con su grupo de amigos o conocidos. En estos casos, prevalecía la presencia de uno 0 dos hombres por cada mujer que los acompañaba.

El grupo se ubicaba en algún punto de la cancha de futbol, en la Calle de la Cruz o en el terreno particular (para el caso de los barrios de Jolalpan), según fuera el caso. Una vez que decidían permanecer en ese espacio los varones que acostumbran beber consiguen licores que comparten con sus conocidos y acompañantes. Cabe mencionar, que socialmente las mujeres pueden beber, pero en menores cantidades que los hombres y del vaso de su esposo o novio, pues no está socialmente bien visto que las mujeres se mantengan con un vaso en la mano durante este tipo de reuniones y menos en la vía pública.

En cambio, socialmente no está mal visto que los hombres arriben solos, acompañados por alguna mujer (amiga, novia y esposa e hijos menores), con el grupo de amigos varones (tres 0 cuatro varones) 0 amigos varones con una o dos mujeres (como se vio en el inciso C), pues es muy común que se encuentren los amigos, parientes y los distintos tipos de compadres en estos espacios. Lo que implica que se consiga una botella de tequila, brandy o ron, para festejar al santo patrón y el hecho de que se encontraron fortuitamente en tanto que dura el baile. Inmediatamente después, aparecen una serie de nuevas normas entre estos varones, como se registra:

a) Una vez aceptando el primer vaso de alcohol, se tiene que beber a la misma velocidad y la misma cantidad que los demás, y b) Nadie se sirve a sí mismo y si algún varón se atrasa con su bebida embriagante, todos los demás lo esperarán a manera de servir la siguiente ronda. Así, una botella de un litro de ron se terminó en tres o cuatro rondas en un grupo de cuatro varones, 
lo que hace vasos con bebidas sumamente "masculinas". La relación hombre-alcohol en el contexto mexicano, según Brandes (2002) dicta que:

"...para los hombres, o al menos para la gran mayoría de los hombres pertenecientes a la clase trabajadora mexicana, la ingesta de alcohol y la embriaguez están estrechamente relacionada con la identidad masculina" (Brandes; 2002: 7).

En los bailes de pueblo aparecen varios tipos de personas: 1) Las que simplemente están paradas observando, platicando y bebiendo con sus conocidos y / o parientes, 2) Los que se dedican exclusivamente a embriagarse, y 3) Varias parejas bailando, que se pudieron haber formado en esos momentos entre desconocidos o entre amigos y acompañantes.

Y a pesar de que los bailes populares y semiprivados estén considerados como uno de los espacios más propicios para encontrar una aventura sexual, novia o futura alianza matrimonial, debido a que la autoridad de los padres se encuentra temporalmente reducida frente a los deseos de su hija, quien decide con quién bailar, con cuánta frecuencia hacerlo y qué tan pegados se hará el baile. Elementos que pueden aumentar en la medida que no se encuentren los progenitores y familiares cerca, además, el tipo de música popular local de "duranguense, banda y corridos" ameritan un contacto más pronunciado entre la pareja que otros tipos de bailes, pero aún así, surgen las primeras dificultades para la formación de estas alianzas temporales, como pueden ser: a) La forma en que está vestido el varón, b) La cantidad de alcohol que ha ingerido y c) su edad. Pues presento la siguiente entrevista y los siguientes casos:

"...También cuando te ven (las mujeres) botudito, arregladito con sombrero y tu ropita vaquera, las muchachas se te acercan, les gusta. También si te ven alegre, que bailas y que te diviertes" (Entrevista con Roberto Delgadillo, habitante de Tepetlaoxtoc centro).

A medida que el varón va ingiriendo más alcohol y se comienza a reflejar en su comportamiento o en su forma de hablar, comienza a ser un obstáculo para encontrar alguna señorita con la que se pueda bailar una pieza, ya que ellas buscan evitar alguna situación incomoda con sus familiares y amigos o que el varón se propasé con motivo de su embriaguez. En caso que el varón alcoholizado insista que la mujer baile con él, la respuesta inmediata es una agresión verbal y después física por parte de los acompañantes y conocidos de la señorita.

Con respecto a la edad, logré observar que las mujeres casaderas que arribaban con su grupo de amigas y que eran acompañadas por algún varón, se podían tomar la libertad de despreciar a cuantos varones arreglados a la usanza vaquera o no, les solicitarán una pieza, pues, cuando la edad era relativamente marcada no se realizaba el baile. En ese caso, la mujer podría seguir despreciando ofertas a pesar de que en toda la noche no bailara ni una sola pieza. 
Uno de los problemas que enfrentan los varones que arriban solos y que desean socializar con las mujeres del baile, es que muy difícilmente un varón se acercará a una mujer que está acompañada por varios hombres o que es la pareja de alguno de ellos, situación que se hace evidente en la medida que comiencen las caricias, abrazos y besos propios de estos eventos. Por lo tanto, la manera más generalizada para la interacción es que las señoritas que van acompañadas de un solo hombre; en estos casos el varón que desea relacionarse, primero se cerciorará de conocer cuál señorita está custodiada y después elegirá a otra del mismo grupo, le extenderá la mano y en caso de ser aceptada se realiza una pieza de baile.

Durante este evento, también se presentan mujeres vestidas a la usanza vaquera y con ellas se "facilita" la interacción, ya que conocen las normas ocultas de estas reuniones públicas y en ocasiones se comparten las mismas redes de amigos, entre ellos se conocen de vista por el tránsito en los pueblos o sus respectivos padres comparten algún tipo de parentesco ritual no sacramental ${ }^{45}$ que les permite relacionarse al ser mínimas las prohibiciones del incesto entre ellos. Ver fotografía 4.

\section{Fotografía 4}

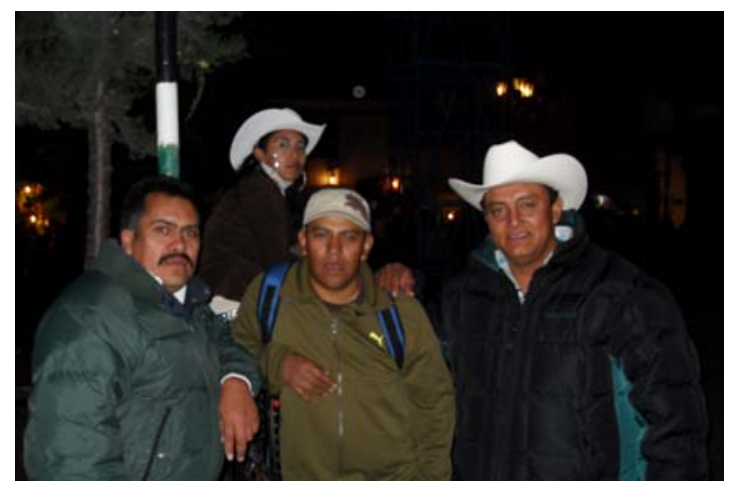

De derecha a izquierda: Con sombrero blanco José Manuel Delgadillo (criador, vendedor y jugador de aves de combate -gallos de pelea-, también labora como repartidor de carne en diversos pueblos del municipio de Texcoco, habitante de Jolalpan, Tepetlaoxtoc), Paul Delgadillo (primo de José, emigrante definitivo del Distrito Federal, se dedica a la reventa de ropa americana en el Municipio de Chiconcuac) y el Ing. Armando Almera (compadre de presentación de José Delgadillo, oriundo de Tepetlaoxtoc centro y se dedica a la venta de ropa en diversos estados del norte de la república, así como la cría, venta y juego de aves de combate). En segundo plano, señorita desconocida y vestida a la usanza vaquera. La fotografía fue tomada durante la serenata de la fiesta grande (Enero 2009).

45 “...la costumbre popular hace caso omiso del dogma e instituye el lazo social del compadrazgo mediante ritos que a los ojos de la Iglesia no crean ninguna relación espiritual, pero que, con arreglo a la costumbre, pueden implicar una prohibición de incesto" (Pitt Rivers; 1979: 599) En este sentido el compadrazgo por amistad no implica prohibición de incesto (por lo menos de la mutua descendencia en Tepetlaoxtoc). 


\section{El primer fin de semana después del 20 de enero.}

Cuando Mauss elaboró su "Ensayo sobre los dones", describió la reglamentación que existe en la circulación obligatoria de las riquezas y los tributos entre los mismos hombres o dirigido hacia los dioses, cito:

"...tanto negarse a dar, como olvidarse de invitar o negarse a aceptar, equivale a declarar la guerra, pues es negar la alianza y la comunión" (Mauss; 1971: 169-70).

El motivo de que los hombres entreguen dones a los dioses, tomando en consideración que éstos fueron los creadores de la tierra y ordenadores del cosmos, como lo comentó Mauss y posteriormente Godelier, se debe a una deuda imborrable que fue previamente adquirida; es decir, la vida humana -y el orden de lo masculino sobre lo femenino. Por tanto, la entrega de dones proveniente de los hombres hacia los dioses, socialmente no son considerados como una opción, sino como una obligación que recuerda esa deuda eterna e impagable.

A diferencia de los hombres: <<los dioses no están obligados a aceptar los dones, y en consecuencia a devolverlos >, pues su condición los precede como los creadores del todo. Por ende, los hombres deben hacer múltiples ofrecimientos a manera de agradar y encontrar el favor de sus dioses, como son:

"...una determinada mentalidad: la de que todo, alimentos, mujeres, niños, bienes, talismanes, tierra, trabajo, servicios, (danzas,) oficios sacerdotales y rangos son materia de transmisión y rendición. Todo va y viene como si existiera un cambio constante entre los clanes y los individuos de una materia espiritual que comprenden las cosas y los hombres, repartidos entre las diversas categorías, sexos y generaciones" (Mauss; 1971: 170-171) ${ }^{46}$.

Y Godelier afirmó:

"Lo que los hombres donan a los dioses son plegarias, ofrendas y a menudo sacrificios, es decir, la ofrenda de una vida, animal o humana" (Godelier; 1998: 256) Y más adelante complementa: "...para que haya sacrificio se precisan víctimas y, a menudo, éstas son, bien seres humanos dependientes (cautivos de guerra, niños y mujeres), bien animales, sobre todo domésticos" (Godelier; 1998: 257).

En ese contexto las danzas regionales de las dancitas, la cuadrilla de las sembradoras, los sembradores, vaqueros y serranos, que se realizan durante las solemnidades de San Sebastián en el centro de Tepetlaoxtoc, son dones que pueden ser descritos de la siguiente manera:

En la mañana del 24 y 25 de enero en la Calle de la Cruz y junto a lo que se podría llamar el atrio de la capilla de San Sebastián (la plaza San Sebastián, Ver mapa 1), se instaló una tarima que sería utilizada desde las nueve de la mañana hasta las diez de la noche por el grupo de los

\footnotetext{
${ }^{46}$ Paréntesis interno y subrayado míos.
} 
vaqueros. Y muy cerca de ellos, se acomodó su banda clásica que toca música de banda popular y duranguense durante la mayor parte del tiempo.

A un lado de la tarima y empleando el resto de la Calle de la Cruz, se ubicaron desde las diez de la mañana la cuadrilla de las sembradoras, quienes entregarían su don hasta las cinco de la tarde, horario en que estaba programada su comida y el inicio de la cuadrilla de los sembradores, quienes culminaron a las once de la noche. Debo comentar, que la banda clásica de estas dos últimas comparsas se presentó en un escenario que estaba ubicado atrás de la cruz de piedra.

\section{La danza regional de los vaqueros.}

Los integrantes de este don para San Sebastián son: El conde (patrón ganadero), las chinas (muchachas casaderas que están vestidas de chinas poblanas y representan a las hijas del patrón), el navarijo (quien contrata y paga a los negros, se distingue por traer un látigo), los negros (semejante a los capataces, se distinguen por traer ropa y el rostro pintado de color negro) y el grupo de caporales (ayudantes de las montas de toros, vestidos con ropa tipo vaquera). Ver fotografía 5 y 6.

\section{Fotografía 5 y 6}
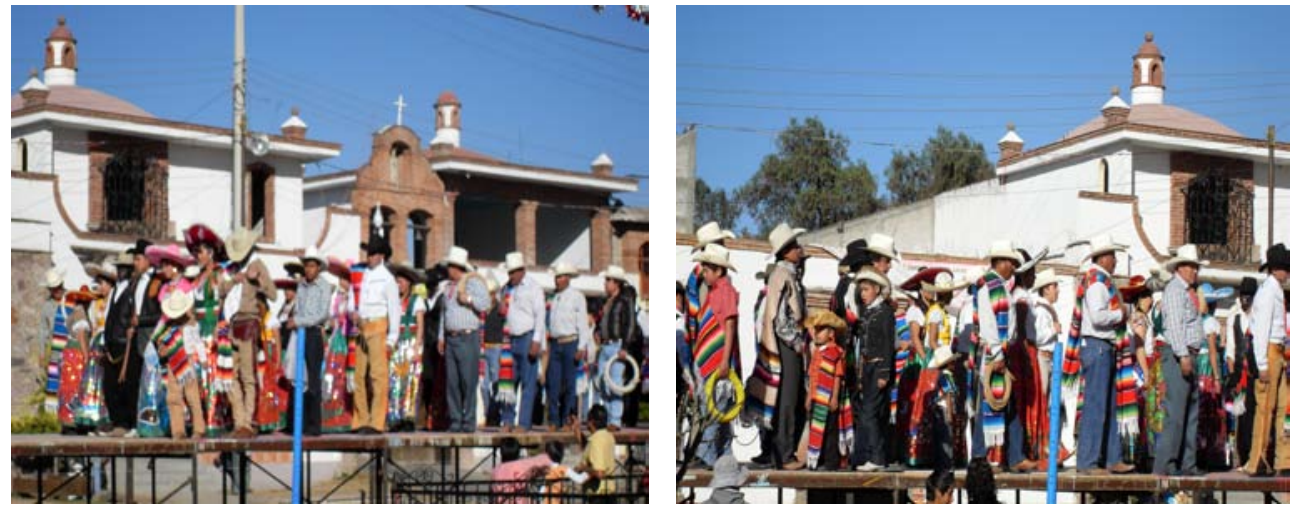

La danza de los vaqueros.

La historia consiste en que un prestigiado ganadero que tiene trece hijas (las chinas), requiere de los servicios laborales de un navarijo, para que a su vez, contrate a los capataces (los negros) y los caporales (los vaqueros) que transportarán sus reces de un punto territorial a otro. Las etapas de la danza regional son las siguientes:

a) El patrón contrata al navarijo.

b) El navarijo contrata a cada uno de los negros.

c) La canción del rodeo.

d) La muerte del toro.

A continuación describiré brevemente cada una de esos puntos: 
Durante la mayor parte del tiempo, los danzantes se dedican a ir y venir, caminando a lo largo de la tarima del escenario. Lo interesante de esta danza ocurre cuando se desarrollan los diálogos entre los participantes, pues, se caracteriza por el uso frecuente de humor negro, dobles sentidos y albures que no caen en la vulgaridad.

El primer dialogo se desarrolla entre el patrón y el navarijo, donde se acuerda su salario y se le otorga un adelanto económico. El navarijo a su vez, tiene la instrucción de contratar a trece negros para que sean los capataces de los caporales que están al servicio del patrón, pero con la indicación de convencerlos para que acepten el pago más bajo posible, por ende, existirán algunos negros que cobrarán menos de la mitad del sueldo que fue sugerido por el patrón. Por su parte, los negros manifiestan su inconformidad con una frase pícara o de burla en contra del navarijo y el patrón inmediatamente después de haber aceptado el trabajo.

Mientras se termina la contratación de negros, los negros ya contratados comienzan a socializar con las chinas poblanas (hijas del patrón), a quienes indistintamente besan, abrazan y declaran su amor en varias ocasiones del baile.

Una vez que todos los negros fueron contratados, inmediatamente se les ordena que se vayan a trabajar y a dar sus respectivas órdenes a los caporales. Pero debido a que la mayoría de los negros están coqueteando con las hijas del patrón, éste tiene que ir personalmente y darles un latigazo en la espalda o en las sentaderas para que acaten la indicación. Los negros responden la agresión con burlas a las espaldas del patrón, besando y abrazando a sus hijas, robando el sombrero del navarijo y cobrando su respectivo sueldo sin haber desarrollado su trabajo.

Durante todo el baile se habla de un toro muy bravo que debe ser montado o matado. Para mostrarlo, el patrón indica a la banda clásica que toque la canción del "ruedo" y algunos de los caporales forman un círculo en la tarima. Dentro del círculo, un caporal se colocó encima del hombro una vaquilla disecada que simboliza al toro que debe ser domado. Alguno de los negros lo torea e inmediatamente después varias de las chinas le piden con frases muy amables y cariñosas que les permitan lidiar con esa res brava. Las chinas torean satisfactoriamente a la vaquilla utilizando sus faldas y recibiendo besos y abrazos por parte de los negros, hasta que se da cuenta el patrón de lo que están realizando sus hijas. Por ende, cancela el ruedo, castiga a los negros quienes responden con más burlas y se continúa con el baile del arreo; es decir, caminar rítmicamente de un lado a otro de la tarima.

Como el toro no se dejará montar, uno de los negros procede a matarlo y supuestamente a repartir equitativamente toda la carne que provenga del animal, pero ese negro ya tiene otros planes, pues, en el momento en que se acercan algunos de los solicitantes por un trozo específico de carne, el negro utilizando un lenguaje con rimas siempre termina por rechazar la 
solicitud. Para finalizar, toda la carne del toro quedó apropiada por el negro quien rinde falsas cuentas de su destino.

\section{Interpretación.}

Este baile se caracteriza por una gran presencia de jóvenes y señoritas casaderas, tal es el caso de todas las chinas poblanas, el navarijo, los trece negros (todos hombres) y algunos caporales de ambos sexos y de distintas edades, pero en ninguno de los papeles participó alguna mujer mayor de los 20030 años o casada y el papel del patrón lo realiza exclusivamente un hombre maduro. A lo que lleva a retomar algunas de las dudas que ya se habían planteado: ¿Cómo se podría definir a un vaquero?, ¿Por qué motivo no participan directamente las mujeres que ya no son casaderas? Y ¿Cómo se podría considerar la labor de las chinas en el ruedo? Con respecto a la primera, esa fue una de las preguntas que tuve que realizar a las personas entrevistadas, y en todos los casos la respuesta era muy parecida a la siguiente:

"...un vaquero es la persona que se encarga de arriar y cuidar las vacas, se visten con camisas a cuadros, sombrero y botas ... por aquí se visten de esa forma en cualquier día del año" (Sr. Víctor Varela, habitante del barrio de la Columna, Tepetlaoxtoc centro).

Consideremos la respuesta temporalmente, que requiere una mayor explicación más adelante. La segunda: Las mujeres casadas ya no participan directamente en esta danza regional, porque se encuentran insertas en el ámbito de lo doméstico, que es más propio a su condición. Y su participación se limita a: a) Vestir a sus hijos para que acompañen a sus padres en la danza, b) Tomar fotografías o video de su familia (hijos y esposo) y c) Proporcionarles agua o refresco a sus hijos danzantes.

En el caso de las madres-esposas cuyos hijos, hijas o esposos están participando en el baile y que éstos se ofrecieron voluntariamente para cubrir el desayuno, la comida o la cena, ellas (las madres-esposas), estarán insertas en el ámbito de lo doméstico preparando las instalaciones, comida, bebida y el servicio para atender a toda la cuadrilla de los vaqueros a la hora acordada. Por ende, la participación de las mujeres casadas durante este baile se recluye en el ámbito privado, doméstico y a sus roles maternales exclusivamente.

Por encima de las señoritas casaderas en general que participan como caporales durante la danza de los vaqueros, resalta el caso de las señoritas que participan de chinas poblanas, quienes tendrán exclusivamente la obligación de costear o cooperar con los gastos para el desayuno, la comida o cena para la cuadrilla en cualquiera de los dos días de su presentación. Lo que orilla a pensar que este baile se presenta como un campo para el prestigio; es decir, se convierte en un espacio que es propicio para presentar el capital económico, simbólico y social 
que pertenecen a los familiares directos de la señorita participante. Capitales que se exponen, corroboran y acrecientan al momento de exhibir a una joven señorita, físicamente hermosa, virtuosa, que está incorporándose al campo matrimonial y al de la reproducción, además de ser la representante de un grupo con suficiente capital económico para costear los alimentos y bebidas de toda la cuadrilla.

Este capital simbólico se acumula y se puede presentar incluso años después en las evidencias documentales o materiales, como son: fotografías, películas o en su defecto comentarios directos, como el que se me realizó:

"Don Rober ....mis dos hermanas participaban de chinas cuando eran señoritas."

(Debo comentar, que "las señoritas" son abuela y bisabuela en la actualidad)

"Mi hijo Pepe bailaba con los vaqueros hace como cinco años, ahora está con los sembradores" Por último, los demás participantes como son los negros, el navarijo y el patrón también deben participar económicamente para cubrir los gastos de la alimentación o la banda clásica.

Con respecto a la china que torea a la vaquilla en el ruedo, se debe entender como una forma de demostrar simbólicamente que las mujeres (en particular las chinas poblanas) pueden realizar la faena al mismo nivel que los hombres, pero al demostrarlo satisfactoriamente se cuestiona a los principios del ámbito masculino en general. La contradicción reclama la presencia del patrón ganadero, quien termina por deshacer el ruedo en el momento que supuestamente observa que sus hijas están arriesgando la vida, cuando en realidad se trata de reordenar el cosmos del dominio masculino que acaba de ser cuestionado e impugnado.

En el caso de las señoritas que participan de caporales, al no realizar ningún dialogo durante el baile a diferencia de las chinas poblanas, y el hecho de formar parte de una "masa anónima" de participantes, reduce su esfera al simple uso del escenario. Pero su condición femenina queda registrada públicamente.

El hecho de que los jóvenes que desempeñan los papeles de los negros o el navarijo, tengan diálogos y una participación más activa a diferencia de los jóvenes y señoritas caporales, les posibilita la interacción con las mismas chinas poblanas o señoritas que están en el público y que desean tomarse una fotografía con alguno de estos integrantes masculinos. A cambio se les entrega números telefónicos o se les manda algún beso hacia el escenario, como lo observé en los descansos de la danza. Esta situación, se puede traducir como un espacio de interacción entre un determinado tipo de jóvenes y señoritas que comparten el mismo status social y que pueden demostrar los distintos capitales propios de sus familias, lo que finaliza por excluir a las 
señoritas o jóvenes caporales quienes su interacción con el público o entre ellos será mínima 0 menos evidente a diferencia de los otros.

Para finalizar, el baile simboliza al patrón explotador y avaro que termina siendo robado en especie (con el toro que tuvo que ser sacrificado) y en su honor. Porque los negros terminan huyendo con las chinas poblanas a los espacios que no son frecuentados por el padre de estas, lo que supone que las parejas terminan teniendo relaciones sexuales extramaritales. Más adelante se ahondará en este punto.

\section{La cuadrilla de las sembradoras.}

La danza de las cuadrillas de las sembradoras y los sembradores se presentaron durante el sábado 24 y domingo 25 de enero. Los participantes de las cuadrillas fueron los siguientes: San Isidro Labrador, un patrón, "su esposa47" María Cristina (que es un hombre disfrazado de mujer), un o una capataz, una contadora, el Hue-hue y de 30 a 50 parejas de sembradores (infantes de ambos sexos y mujeres u hombres -dependiendo a la cuadrilla que se refiera-). Se debe mencionar, que todos los participantes son voluntarios que apoyaron económicamente en cualquiera de los tres rubros, como son:

1) La compra de frituras y dulces.

2) El pago de la banda clásica que tocará música especial de este baile y también popular.

3) Costear los gastos del desayuno y la comida de su cuadrilla.

Los bailarines comienzan a arribar después de la hora citada (diez de la mañana), la cuadrilla de las sembradoras se caracteriza por presentar un número considerable de infantes de ambos sexos y adultos que en su mayoría son mujeres (Ver fotografía 7). La razón se debe a una cita frecuente de Héritier:

"...el hombre accede a través del matrimonio al estatus de adulto. Su clan maternal le provee la inmanencia, pero él quiere la trascendencia. La prohibición del incesto se convierte así en la marca de la voluntad masculina de ir deliberadamente hacia lo desconocido, hacia el Otro, hacia lo que él no es. Juega con el riesgo." (Héritier; 2007: 99).

\footnotetext{
${ }^{47}$ Cabe mencionar, que no existe un acuerdo general en el Acolhuacán Septentrional sobre este papel, pues para algunas localidades María Cristina es la esposa, en otras puede ser: la tlacualera (mujer que lleva los alimentos), la aventura o consuelo sexual del patrón. En el caso de Tepetlaoxtoc, se le considera como la esposa del patrón.
} 
Fotografía 7

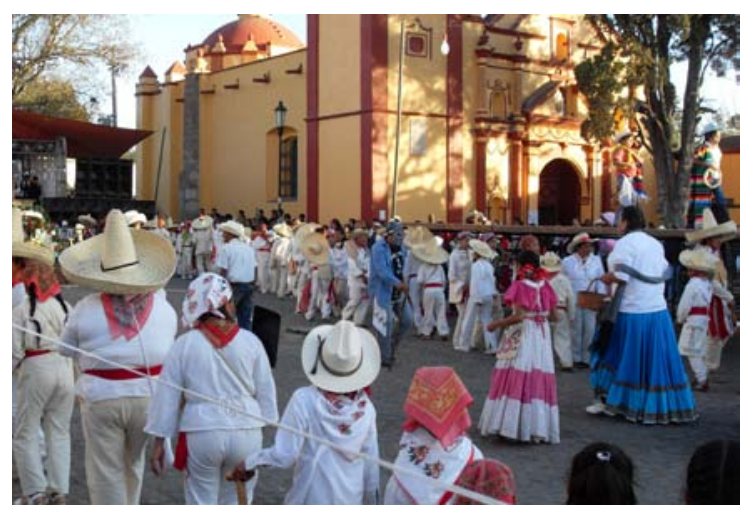

Cuadrilla de las sembradoras.

En segundo plano: la Capilla de San Sebastián, el Hue-hue utilizando ropa de color azul, máscara y bastón. De espaldas María Cristina con una falda azul y su "hija" usando falda rosa.

Uno de los detalles que son relevantes de mencionar, es que en ambas cuadrillas (sembradoras y sembradores) los papeles del capataz y el contador también son representados por mujeres. Cuando en otras comunidades del Acolhuacán Septentrional son realizadas exclusivamente por varones (Ver fotografía 8). En el apartado 2.3 Espacios para lo femenino, se ahondará sobre la participación de las mujeres en papeles propios para los hombres (la capataz y la contadora). De la misma forma, será retomado el punto pendiente sobre las chinas poblanas de la danza de los vaqueros.

\section{Fotografía 8}

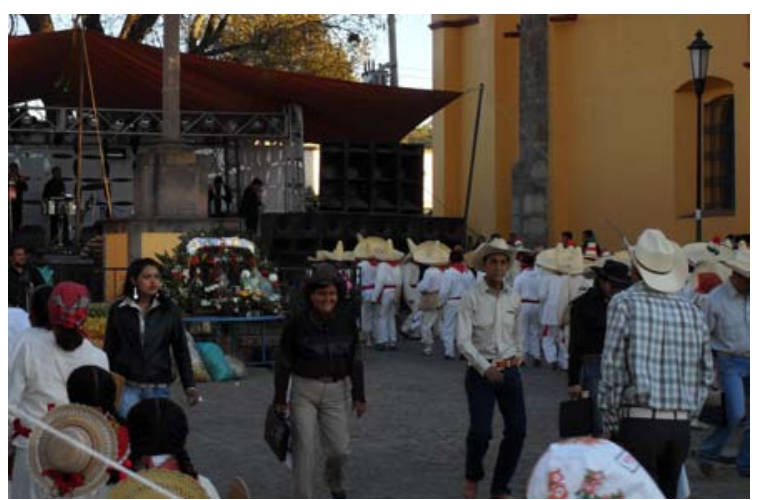

El patrón, las contadoras y el capataz.

En el segundo plano, se distingue la base de la cruz de piedra y una imagen portátil de San Sebastián. Del lado derecho de la imagen, se puede apreciar una pared de la capilla de ese santo.

Para comenzar con la entrega del don, el patrón, la capataz y contadora se hincan en dirección de cruz de piedra, detrás de los primeros se mantiene de pie María Cristina, que a su vez, es seguida por dos filas paralelas de sembradores también hincados. Todos en conjunto, solicitan 
permiso a San Sebastián para realizar el baile e inmediatamente la banda clásica comienza a tocar un son especial. La danza se caracteriza por las siguientes etapas:

a) La contratación de los peones o sembradores y compra de la semilla.

b) El barbecho y hacer los surcos con la yunta.

c) Peticiones a San Sebastián y San Isidro para que se logré la cosecha.

d) El voleo (regar la semilla).

En todos los casos el paso de todos los danzantes es el mismo, pero las diferencias son en el ritmo y en el uso de los instrumentos de labranza, por ejemplo: en la contratación de la mano de obra, los campesinos van en pareja (aludiendo a que son un matrimonio inmigrante de temporal) que se presentan en este caso con la capataz. Ella o él, les asignará el sueldo a percibir y el espacio que tienen que labrar. Durante el barbecho, las sembradoras fingen que trabajan con sus palas de madera, también aparece una yunta que es tirada por un par de bueyes de cartón, que recorre todo el escenario a manera de simbolizar que se están haciendo los surcos para la siembra. Una vez que se finalizó con el barbecho y los surcos, el patrón, la contadora, el o la capataz realizan constantes plegarias a San Sebastián Mártir y a San Isidro Labrador para que se logre la siembra y la futura cosecha que se pretende obtener, y a sus plegarias se les suman los demás actores (los sembradores). Con respecto a la banda de música, esta trata de extender el tiempo entre cada una de las etapas con música popular de banda, por ende, esta danza puede fácilmente durar una o dos horas seguidas.

Una vez que se acabaron las plegarias y se obtuvo el favor de los santos para realizar la siembra, las sembradoras se dirigen hacia el frente del escenario sin romper la formación que han mantenido desde que inició el baile. En el escenario se le entrega a cada uno, una serie de "semillas" que tendrán que ser esparcidas por todo el campo agrícola que fue simbólicamente labrado para la siembra. En el momento en que todos los miembros de la cuadrilla tengan sus respectivas semillas, que consisten en bolsas de dulces y frituras, el patrón da la orden de comenzar con la técnica agrícola del voleo; es decir, arrojar la semilla en el campo de siembra (el público espectador). Lo que implica que las supuestas semillas terminan cayendo en las manos del público asistente. Cabe mencionar que María Cristina y el Hue-hue, también arrojan "semillas" al público.

El baile de las sembradoras se repite una y otra vez, hasta que sean las cinco de la tarde, horario en que comienzan a arribar la cuadrilla de los sembradores, además de ser el horario establecido para ir a comer. 


\section{-Los sembradores-}

Como se había comentado anteriormente, este tipo de baile se encuentra extendido en el territorio del Acolhuacán Septentrional, pero deseo resaltar el caso de los pueblos de la Resurrección y Xocotlán, ambos pertenecientes al municipio de Texcoco. Parte de su comparsa local, se presentó durante estos dos días acompañando a la cuadrilla de los sembradores de Tepetlaoxtoc, en base a la reciprocidad dancística que existe entre estas comunidades.

Con respecto a la cuadrilla de los sembradores de Tepetlaoxtoc, su presentación sigue el mismo principio que el de sus antecesoras. Donde las únicas diferencias plausibles entre una presentación y la otra es que:

1) La cuadrilla de sembradores comienza a las cinco de la tarde para finalizar a las once de la noche, horario que es más propio para el ámbito masculino.

2) En la cuadrilla de los sembradores, prevalecen el número de varones (mayores de edad), frente a un reducido número de mujeres que desean participar o que se incorporaron después de su presentación anterior. Cabe comentar, que la mayoría de los infantes que participan en esta cuadrilla, son varones. Ver fotografía 9 y 10.

3) Se permite que los miembros de esta cuadrilla ingieran bebidas alcohólicas durante los breves descansos que se otorgan. Situación que no se presentó en la cuadrilla anterior.

4) En la cuadrilla de los sembradores, María Cristina que es la esposa del patrón, presenta un comportamiento inmoral al realizar insinuaciones de tipo sexual al Hue-hue. Éste, aprovecha la situación para manosearla, nalguearla y en ocasiones se caen a causa de sus movimientos tan eróticos que muestran ambos participantes. Situación que no se observó en ningún momento de la presentación anterior que se realizaba a plena luz del día.

5) Las semillas de esta cuadrilla, consisten en frituras, naranjas y piñas Ver fotografía 11. con respecto a estas últimas, se entregan en propia mano de los solicitantes, pero debo aclarar que la mayoría de los casos, las piñas terminan en las manos de los familiares y parientes rituales de los mismos sembradores.

6) A las once de la noche finaliza la presentación y los participantes se van al sitio destinado para la cena. 


\section{Fotografía 9}

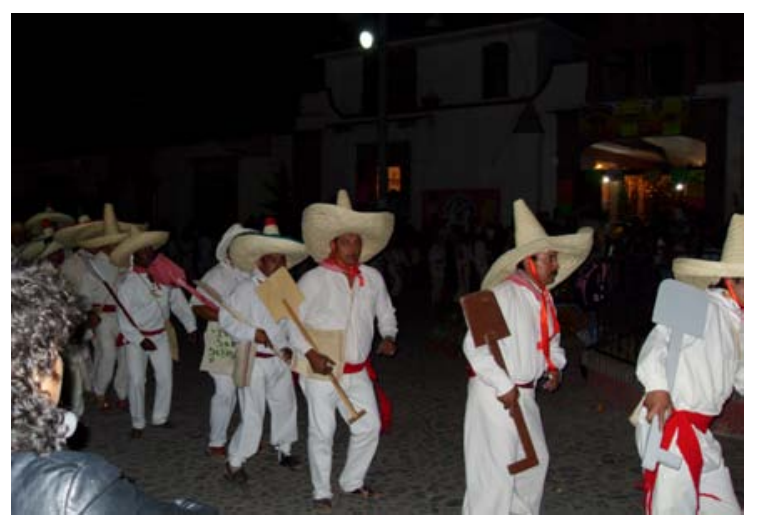

Cuadrilla de los sembradores.

Fotografía 10

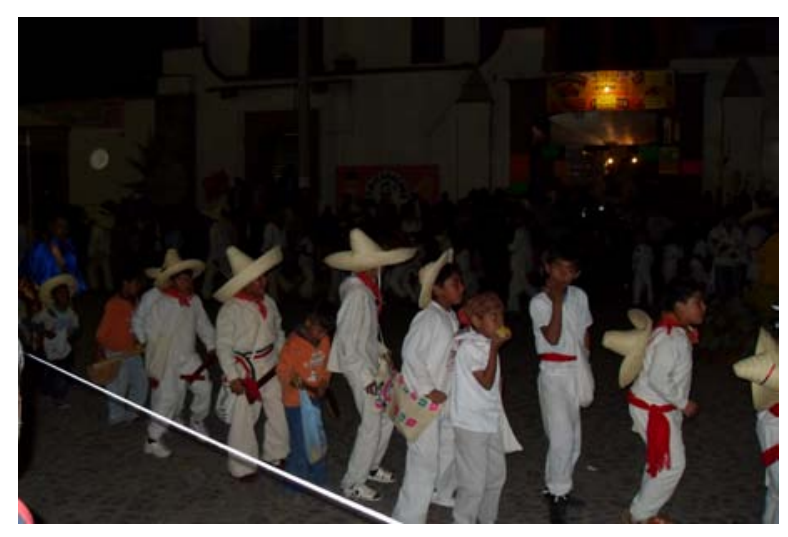

Los infantes de la cuadrilla de los sembradores. Al final de la fila se encuentra San Isidro Labrador

\section{Fotografía 11}

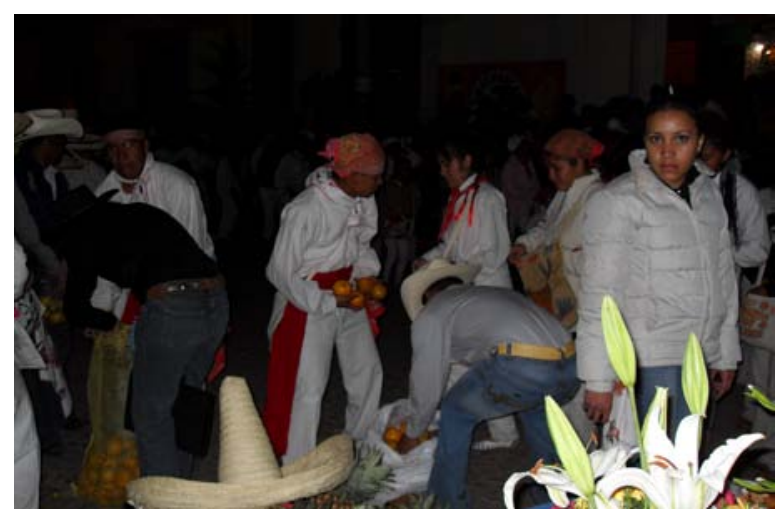

Las semillas de los sembradores para el voleo. 


\section{Interpretación de los sembradores y las sembradoras}

"La conexión de las fiestas de cosechas pueden decirse que, en gran parte, tienen relación con el santoral cristiano. La tradición dicta unas normas generales en algunos casos y particulares en otros. En el calendario cristiano hay una fiesta movible dentro del referido ciclo temporal destinado a Cristo, que por tradición recoge una gran cantidad de elementos, de origen diverso, que se encuentran en diferentes fiestas de la Virgen María y otras en los meses de junio, julio, agosto y septiembre. Esta fiesta es la de Corpus Cristi; se llama así a la celebración católica dedicada a conmemorar la institución de la Eucaristía, la acción de gracias, el sacramento instituido por Jesucristo que se fijó después del domingo de la Santísima Trinidad. (Romero, 1981)"

(Sánchez Valdés; 1997: 35)48

Por esa razón, se puede entender el sentido de la comparsa de ambas cuadrillas de sembradores y las etapas que tiene su presentación. Pues, la contratación del peonaje y la compra de semillas, después el barbecho y las plegarias a los dioses, seguido de la siembra, son actividades y parte de las etapas propias de la siembra-cosecha de las zonas agrícolas mesoamericanas. Y a manera de otorgarle un mayor realismo a la danza, esta coincide con el inicio de la temporada de lluvias en el Acolhuacán Septentrional.

Tomando en cuenta que los carnavales son espacios públicos, anónimos, que permiten la fantasía, inversión de roles...
Y están "...dominados por la brincadeira, diversión o licencia, es decir, situaciones en la que el comportamiento está dominado por la libertad como resultado de la suspensión temporal de las reglas de una jerarquización represora" (DaMatta; 2002:59), donde los participantes del carnaval -continuo retomando-: "...son figuras periféricas del mundo social ...Los reyes, duques, príncipes y otros nobles; los fantasmas, calaveras, diablos y otros personajes del mundo de las sombras ...cowboys y otras figuras extremas que lo cotidiano sólo revela dolorosamente" (DaMatta;2002:72-73)
Y sigue: "El tiempo de carnaval está marcado por la relación entre Dios y los hombres, y tiene, por eso mismo, un sentido universal y trascendente. Así, el comienzo del carnaval se pierde en el tiempo -porque está ligado a toda la humanidad, del mismo modo que pensar en el tiempo del carnaval es pensar en términos de categorías abarcadoras como el pecado, la muerte, la salvación, la mortificación de la carne, el sexo o su abuso y continencia. Precisamente porque se define como un tiempo de licencia y abuso, el carnaval conduce de un modo abierto a la focalización de valores que no son solamente ...cristianos. ...la cronología del carnaval es una cronología cósmica, directamente relacionada con la divinidad y las acciones que llevan a la conjunción o disyunción con los dioses" (DaMatta; 2002: 65).

DaMatta muestra diversas oposiciones entre el carnaval y los desfiles militares. Donde estos últimos, se caracterizan por tener un tiempo específico de inicio y de final, el orden prevalece y

\footnotetext{
48 Subrayado mío.
} 
sus participantes se encuentran vestidos de manera homogénea al batallón 0 al cuerpo militar al que pertenezcan.

Retomando los elementos anteriores, sugiero que la danza de los sembradores será un híbrido entre ambas categorías, porque: 1) Existen dos personajes (María Cristina y el Hue-hue) de tipo carnavalesco; es decir, son actores que participan de la fantasía y que su condición les permite contradecir las reglas sociales establecidas sin recibir una censura o represión por parte de las autoridades civiles y / o religiosas durante el tiempo cósmico de la danza. Donde el Hue-hue es un anónimo que representa a un anciano con una joroba, un excluido social o una celebridad pública. Con respecto a María Cristina, es la esposa del patrón de la finca o hacienda, pero el papel es representado por un hombre debidamente disfrazado que usa una canasta, sin ocultar sus facciones de un rostro varonil.

2) El elenco se complementa con personas de ambos sexos que están vestidos con calzón y camisa de manta, huaraches, sombrero de paja de forma homogénea, que serán seguidos por un varón disfrazado de San Isidro Labrador.

Por último, se presentan tres o más danzantes que portan ropa de tipo vaquera, pero que se distinguen uno de otro por el sitio que ocupan en la danza y algún elemento simbólico, como puede ser: un látigo en el caso del patrón, una carpeta o portafolios en el caso del contador y la voz de mando en el caso del capataz. Debo mencionar, que estos últimos tres papeles son desarrollados por mujeres y algunos hombres.

La danza respeta las etapas del ciclo agrícola, pero el contexto en el que se desarrollan los diálogos, la existencia de la tienda de raya y la rudimentaria tecnología de siembra que se utiliza, remiten a los años previos a la revolución mexicana de 1910. En ese sentido, el patrón llega a un acuerdo con el capataz a manera de explotar lo más posible y endrogar a todos los peones que serán contratados.

Los peones se acercan al capataz en parejas simbolizando que son marido y mujer que han emigrado de manera temporal a esta región del país, algunas ocasiones los acompañan infantes que dan un toque más realista a esta teatralización, pues se puede suponer que es el matrimonio que emigró con sus hijos. El capataz acuerda con los peones la cantidad del sueldo a percibir y sus futuras deudas en la tienda de raya, por ende, se les indican a la pareja de peones que se dirijan a la tienda de raya para recibir sus instrumentos de labranza que les será cobrado a su debido tiempo.

Por su parte, el contador comienza a llevar el registro de los gastos que van derogando la contratación, las deudas que adquieren los peones en la tienda de raya, la compra de semillas que requiere la siembra y los gastos que derogan la contratación de la yunta. 
Aparte, todos los participantes tendrán la obligación de realizar plegarias dirigidas a San Sebastián y San Isidro Labrador para que llegue el periodo de lluvias, pero de forma controlada y constante. En este punto es importante recordar, que:

"Con el objeto sagrado (que puede ser una danza, un rezo, sacrificio, objeto material, etc.) se persigue, en el nivel de acción y el rito, la misma inversión que existe en el nivel de la representación. Pues precisamente ahí donde el hombre no puede hacer nada con la realidad, como por ejemplo multiplicar las especies salvajes que caza y pesca, o hacer que las aguas del Nilo vuelvan cada año llenas de limo fecundante, es donde (desea y) cree tener el poder de actuar sobre los seres que sí poseen dicho poder. De ahí los ritos de fertilidad, de multiplicación de las especies animales y vegetales ...Es evidente que, para que ese poder aparezca como $<<$ real $>>$, es preciso que todos compartan esta creencia y que puedan exhibirse de vez en cuando pruebas <<reales $>>$ de la eficacia del rito y del objeto" (Godelier; 1998: 250-251) ${ }^{49}$.

Una vez que ya se cree que se tiene el apoyo de ambos santos patrones, se comienza con la siembra.

En todos los momentos anteriormente descritos, los actores continúan danzando, y surge un detalle: El Hue-hue se dedica a acosar sexualmente a la esposa del patrón (María Cristina). Ella, con su fragilidad, debilidad y calidad de mujer no puede defenderse de las agresiones sexuales que perpetúa el Hue-hue, pero tampoco solicita ayuda o protección de su marido. Cabe aclarar, que en las ocasiones que el patrón se dé cuenta de los acosos sexuales, simplemente se limitará a tratar de castigar o ahuyentar al Hue-hue con su látigo, pero en ningún momento existe alguna acción que le prohíba al Hue-hue realizar sus acosos.

En ese sentido, se puede comenzar a cuestionar los supuestos acosos sexuales del Hue-hue en contra de María Cristina, pues, durante la danza también son visibles las constantes insinuaciones de tipo sexual que ella da al Hue-hue. Por lo tanto, se puede concluir que María Cristina en su facultad de esposa del patrón contradice su posición social en varias veces y en otras tantas se encuentra disponible sexualmente para el Hue-hue o alguna otra persona.

Respecto a la cuadrilla de los sembradores concluimos: a) Reducen en pocos minutos u horas, varios días de trabajo y el temporal agrícola que requiere de meses, en otras palabras: es un tiempo cósmico de la cosecha, b) El baile de los sembradores es una suerte de rito histórico de paso -en términos de DaMatta (2002) quien se inspiró en Turner-, ya que su performance busca recordar y recrear parte de las condiciones sociales que orillaron al movimiento revolucionario de 1910. Y a su vez, este ritual enfatiza los movimientos indígenas del siglo pasado, c) Se presenta un cuadro de tipo carnavalesco que involucra solamente a dos personajes (el Hue-hue y María Cristina), porque se realizan constantes contradicciones de los papeles sociales que otorga el

\footnotetext{
${ }^{49}$ Paréntesis interno mío.
} 
capital económico y el prestigio social aunado a constantes insinuaciones sexuales que se pueden hacen extensivas a otros miembros de la cuadrilla. Por ende, la comparsa de los sembradores está relacionada con los ciclos agrícolas, la memoria histórica, pero también con una utopía social. Es decir: el patrón desde el momento que establece la cantidad a pagar y la forma en que se llevará a cabo el cobró de los intereses de los artículos que se obtengan de la tienda de raya, está ganado económicamente por ambas partes y amplía la brecha de las clases sociales como la relación de los explotados y el explotador. El desenlace del ritual performativo, indica que el único ganador después de la cosecha continúa siendo el patrón, mismo que volverá a contratar a más peones una vez que se haya levantado toda la cosecha. Pero la polisemia del ritual denota que María Cristina se encuentra disponible sexualmente tanto para el Hue-hue como para algún otro participante. Lo que implica, que la esposa del patrón será constantemente utilizada de manera sexual por cualquiera de los participantes menos por su marido. Por lo tanto, el pueblo es explotado físicamente por el hacendado, pero todos los hijos que le nazcan a su esposa, muy difícilmente él será el padre. Ya que María Cristina recogerá en su canasta el fruto de la semen-sangre de cada una de sus infidelidades. Porque, retomo de Héritier:

"A la escala universal, las organizaciones simbólicas y las organizaciones sociales que allí surgen implican -como se sabe, aunque no éste demostrado etnológicamente- una estrecha dependencia de las mujeres en todos los sectores: una exclusión de los ámbitos político, económico, cultural, religioso; una asignación casi exclusiva a la esfera de lo doméstico (en el doble sentido de que las mujeres están obligadas y los hombres no); una privación a veces radical de la educación, del pensamiento, de la palabra, de la libre decisión; una desvalorización de sus actividades y su propio ser que incluso puede calificarse como una denigración sistemática; una condena a no existir jamás como individuos plenos -salvo como esposas y sobre todo como madres- y en la igualdad con los hombres ...las mujeres fueron confinadas en todas partes a un rol de procreadoras domésticas, excluidas del uso de la razón, excluidas de lo político, excluidas de lo simbólico. En este último punto es donde se juega la fuerza física del hombre" (Héritier; 2007: 177-178).

De las generalidades que se pueden comentar de la danza de los vaqueros y sembradores y las sembradoras, destacan:

1) Las danzas regionales son campos donde se puede poner en juego el prestigio social y sirve como un espacio para demostrar algunos capitales, principalmente en el ámbito económico.

2) En cualquiera de los tres bailes, se permite la participación de vecinos de otros pueblos de Tepetlaoxtoc, resalta el caso de los habitantes de los distintos barrios de Jolalpan. 
3) Se deben considerar como espacios sociópetos que se manifiestan entre los mismos participantes o con personas del público.

4) El intercambio de danzas entre los pueblos del mismo municipio o con otros que pertenecen al Acolhuacán Septentrional, permite la formación de lazos de amistad que pueden desembocar en algún tipo de parentesco religioso o en una futura alianza matrimonial.

5) En el caso de las cuadrillas de sembradores y sembradoras, apareció un hombre disfrazado de mujer (María Cristina) y los papeles de las autoridades del rancho lo escenificaron mujeres. Por otra parte, en el baile de los vaqueros, se presentó el hecho de que las chinas poblanas se atreven a torear al toro o la vaquilla, como una suerte de demostración de la capacidad de las mujeres de realizar el mismo trabajo que socialmente tendrían prohibido, estén o no los varones. Elementos que deberán ser cuestionados más adelante, ya que "...todo orden social, es a la vez, un orden sexual" (Godelier; 1997: 24).

\section{El palenque y el jaripeo del día domingo.}

El día domingo 25 de enero se presentó un jaripeo-baile en el barrio del Calvario en el centro de Tepetlaoxtoc. Pero como también se recuerda, en este día se festeja a San Pablo en el barrio del mismo nombre en Jolalpan. Fue en este último donde se presentó un palenque con motivo a la celebración del santo local, y durante la madrugada se presentó su rodeo de media noche. En este ensayo solamente referiré al jaripeo que se realizó en el barrio del Calvario durante los festejos de San Sebastián.

Para conocer una breve historia del arribo del ruedo propio de los palenques y jaripeos o rodeos en América, sugiero consultar al Anexo 3.

\section{El jaripeo.}

Para ilustrar mejor este punto, presento el siguiente fragmento de una canción popular:

$$
\begin{gathered}
\text { “...Me dijo con certeza que no hay más emoción } \\
\text { que romper un sombrero disparar un cañón } \\
\text { salvar la vida de un jinete cuando mal anda su suerte } \\
\text { Ser payaso de rodeo hoy } \\
\text { Les digo ven, ven, ven, animalito ven, } \\
\text { Ven y sígueme y veras lo que vas a aprender, } \\
\text { No ves que soy muy poco artístico } \\
\text { Muy listo muy gracioso soy payaso de rodeo" }
\end{gathered}
$$

(Fragmento de la canción: "Payaso de rodeo" del grupo Caballo Dorado). 
La distinción entre un jaripeo y un rodeo, es que en este último se han introducido figuras como el payaso de rodeo, quien cumple la función de quitar un toro embravecido a un jinete que recientemente ha caído para evitarle más heridas. Cabe mencionar, que los rodeos tienen más auge en la región norte del país y en los Estados Unidos, en cambio los jaripeos son más propios de la región central del territorio nacional, pero en el fondo consisten en el mismo principio como se verá a continuación:

Con motivo a la fiesta de San Sebastián Mártir en el centro de Tepetlaoxtoc, los miembros de una familia local, dieron aviso a sus conocidos del municipio o de otros vecinos, y además, colocaron en la calle de Xolaltenco una manta que anunciaban la hora y lugar del jaripeo que se desarrollaría el día domingo de esa misma semana. Este sería a las 2:00 p. m., en un terreno particular que está en frente del CBT (la escuela preparatoria local), en la calle Fray Pedro Duran esquina con Ocoyococ (Ver mapa 1). Horas antes de iniciar el evento llegó un camión cargado de la estructura metálica, se instaló un escenario con luces y sonido para el grupo de banda, y se acordaba la hora en que se iban a bajar todas las reces que serían montadas. Por diversas circunstancias el jaripeo comenzó una hora tarde, pero una vez listo, se solicitó a los asistentes que se quitarán temporalmente sus sombreros, a los jinetes pararse en el centro del ruedo y a todos los presentes escuchar la oración del jinete, que dice:

"Señor, nosotros los jinetes no te pedimos favores especiales, solamente nos des valor y destreza para realizar nuestras montas en cada uno de los jaripeos donde arriesgamos la vida.

Señor, tú que fuiste jinete del Apocalipsis en esta vida, vida que quieres que vivamos, con el único fin de ganarnos el pan de cada día y divertir a tus hijos, queremos pedirte humildemente que llegando el último e inevitable gran jaripeo para nosotros:

Cuando las piernas con todo y espuelas se aflojen

Cuando nuestros brazos no soporten el chicoteo del último reparo

Y tú señor nos llames allá contigo, donde todas las tardes serán de triunfo y gloria para nosotros, nos digas: ¡dale puertas, fuera capas! Vengan mis cabezales valientes, tu monta la he dado por buena."

Linkografía:http://mx.answers.yahoo.com/question/index?qid=20060921095056AAQQV7d

Una vez finalizada la oración, el primer jinete eligió la res que montará. El animal es sacado con violencia del establo provisional que forma parte de la estructura metálica, y se trata de llevarlo por todos los medios posibles al cajón de montar. Una vez ahí, los otros jinetes, en muestra de solidaridad con su compañero, amarrarán a la res con el pretal y le colocan las espuelas al jinete que la montará. Mientras se desarrolla todo esto, la banda contratada tocaba música de propia de su nombre, corridos y del género duranguense. Además de hacer comentarios positivos sobre los jinetes y las reces, el animador invita al público para que solicite alguna canción o hacer una 
dedicatoria. Se realizan constantes propagandas a la oferta de pequeños servicios como eran las cuatro cantinas temporales que se instalaron en diversos puntos de este terreno. Son negocios que darán una cooperación económica a los organizadores del jaripeo al finalizar la venta. Cabe mencionar que este terreno sufrió constantes transformaciones y usos de su espacio durante estos días de festejo, pues de propiedad particular paso a ser estacionamiento público con servicio de baño público y con un expendio temporal de cerveza; después, se colocó el ruedo del jaripeo-baile y ese mismo día en otra parte de su espacio, se utilizó como arena para la demostración ecuestre. Por último, volvió a ser estacionamiento público con expendio de cerveza hasta que finalizó los festejos y retornó a su condición particular.

Una vez que el toro estaba en el cajón y el jinete ya se encontrara en disposición de realizar su demostración, éste sólo necesitaba gritar: ¡PUERTA! Para que fuera abierto el único acceso al cajón y comenzar así "la monta". Debido a que es un espectáculo de tipo gratuito y semiprofesional, los tiempos requeridos para preparar a las reces eran cortos y ágiles, que se compensaban con los pocos segundos que duraba el jinete encima del toro. Cabe apuntar, que tanto los organizadores como algunos de los jinetes que participan en el jaripeo son todos miembros masculinos de la misma familia, parientes rituales y amigos de la misma. Por ende, los organizadores y los participantes pertenecían a los pueblos de Tepetlaoxtoc centro y al rancho la Palma en Jolalpan; fueron los únicos que presentaron sus demostraciones.

Cabe mencionar, que los pueblos de los Reyes Nopala y San Juan Totolapan, se caracterizan por ser las entidades en los que se efectúan más jaripeos y rodeos, en comparación de las demás comunidades del municipio.

Por otra parte, debido a que la estructura metálica del jaripeo no contempla gradas, la mayoría de los asistentes estaban parados lo más cerca del ruedo, otros sentados en la misma estructura temporal, otros realizaban demostraciones ecuestres (hacían bailar a su caballo) y un menor número se conglomeraba en las bardas 0 en las paredes para observar y beber bebidas embriagantes. La mayoría de los asistentes son hombres en comparación a las mujeres que acompañan a sus familiares, a su novio, marido o están cuidando a sus hijos que pidieron asistir a este evento. Por ende, este evento es de tipo familiar, donde las redes sociales (amistades), vecinos y lazos de parentesco consanguíneo y ritual se reactivan en este momento provocando que exista un circuito de intercambio de bebidas alcohólicas y cigarros entre agentes masculinos que están en varios puntos del jaripeo. Situación que a su vez, provoca constantes invitaciones para cenar en algún solar de un familiar o conocido de la comunidad, además de permitir que se formen nuevas redes sociales para conocer alguna señorita que desee bailar alguna de las piezas que toca el conjunto. En este caso, nuevamente se reactivan las mismas normas sociales 
que se presentaron en el baile; es decir, será motivo de un menor conflicto invitar a bailar a una amiga o conocida, que a una extraña que está acompañada por un número desconocido de hombres, donde la edad y la cantidad ingerida de alcohol también marcarán la diferencia.

\section{Análisis del jaripeo.}

Primero, se debe reconocer que las mujeres se encuentran socialmente excluidas del ámbito de la representación simbólica y del espacio público, parámetros que son apropiados por los hombres y disputados entre ellos mismos. En ese sentido, las mujeres que no son estériles también quedan excluidas de participar activamente de los espacios públicos que están destinados para los actos violentos y propios del derramamiento de sangre. Por ende, su aportación durante estos esquemas será simplemente como espectadoras de las habilidades masculinas de sus maridos o hijos varones. Porque cito de Bourdieu:

"...los juegos sociales (illusio), que hace el hombre que es hombre de verdad: sentido del honor, virilidad ...es el principio indiscutido de todos los deberes hacia uno mismo, el motor 0 el móvil de todo lo ordenado, es decir, que debe realizarse para estar en regla consigo mismo, para seguir siendo digno, ante los propios ojos, de una cierta idea del hombre" (Bourdieu; 2000:66-67).

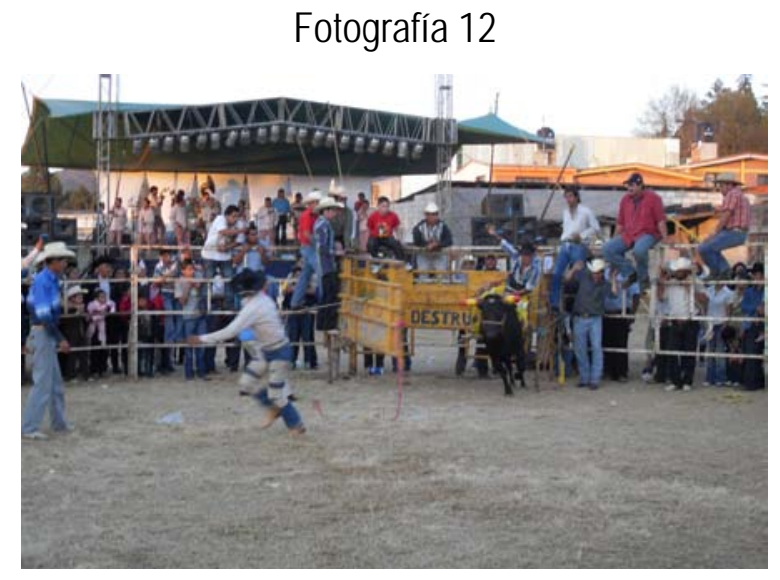

Jaripeo en honor a San Sebastián en el barrio del Calvario, Tepetlaoxtoc centro.

¿Se pueden considerar a los jaripeos como arenas políticas y simbólicas?, ¿Qué imagen proyectaría alguna mujer que participe activamente en un rodeo o en un jaripeo realizando actividades propias del ámbito masculino? Tomaremos como un referente la definición de arena:

"La analogía de arena, tomada de una corrida de toros o de una lucha entre gladiadores, tiene tres elementos que el mismo Turner destaca: a) Se trata de un antagonismo -simbólico o factual- que puede tomar formas diversas según las expresiones culturales. b) Se da en un marco explícito. c) Se pretende llegar a una decisión pública ya sea mediante la persuasión, la amenaza o la fuerza"

(Varela; 2005: 103). 
Los tres elementos que enfatizó Turner (citado por Varela), indican que los jaripeos o rodeos son arenas políticas propias para la demostración de la virilidad y también son espacios simbólicos que permiten acrecentar el prestigio social masculino con la ley de contacto. Si se toma como referente la faena de toros; es decir, un torero que abandonará el ámbito femenino para incorporarse al masculino en base al desarrollo del ritual, donde el toro va muriendo heredándole a su verdugo sus cualidades, así se recrea el dominio masculino culturalmente construido, como lo sugiere Pitt-Rivers (1997). De manera análoga, el jinete del jaripeo al exponerse a montar un toro embravecido, busca explotar y amasar en una sola esencia tanto las más preciadas virtudes humanas como la bravura y fuerza del animal debido a la ley de contacto.

En ese sentido, el control que puede ejercer el hombre sobre la bestia incrementa sus parámetros de virilidad del primero a pesar del poco tiempo que dure sobre el segundo. Por ende, se puede llegar a suponer que la monta de toros es simbólicamente análoga al control del falo o la fuerza sexual de cada uno de los jinetes. Argumento que se puede sostener, en la medida que comienza a ser evidente una autoidentificación entre las particularidades del animal inscritas en el cuerpo del hombre. Por ejemplo:

\footnotetext{
"Yo soy ese toro grande que atrae todas las miradas No más al entrar al baile, deje un troconón parqueada Sé que soy el mero padre y jefe de la manada"
}

(Fragmento del narcocorrido: "El toro grande" del grupo Exterminador)

¿Qué imagen proyectaría alguna mujer que participe activamente en un rodeo 0 en un jaripeo realizando actividades propias del ámbito masculino? Al plantear esta pregunta en el caso del jaripeo y de los palenques, aparecieron los casos de mujeres que participan activamente en estas dos actividades simbólicas propias de lo masculino, pero los resultados no siempre fueron los mismos. Con respecto al jaripeo, se me comentó del caso de una señorita oriunda de algún barrio de Tepetlaoxtoc, que hace años se dedicaba a la monta de toros. Los resultados eran los mismos que los demás jinetes, una casi inevitable caída del animal. En cambio, las consecuencias sociales e impresiones públicas eran positivas, como lo dicta la siguiente entrevista:

"Yo sí vi el caso de una señorita de Tepe (Tepetlaoxtoc centro) ...ya está casada y tiene sus hijos, pero antes sí montaba en los jaripeos. Ahora ya no la he visto que monte, pero al final todo el público le aplaudían, porque le había entrado al toro, pues no es lo 
mismo verlo que montarse. Yo también montaba, hace como tres años deje de hacerlo, porque ya no es lo mismo" (Entrevista a Roberto Delgadillo habitante del barrio de la Asunción, Tepetlaoxtoc centro).

Lo interesante del anterior testimonio, es preguntarse ¿Por qué dejó de montar la señorita después de casarse, sí lograba la admiración del público en general? Héritier podría argumentar, cito:

“...la idea de la fecundidad o de maternidad es reverenciada. La valorización de la mujer como madre no es forzosamente algo bueno para la condición femenina, y la reverencia hacia la maternidad se duplica rápidamente en el confinamiento de la mujer a la vida doméstica y a los roles maternales" (Héritier; 2007: 123) Posteriormente comenta: "...lo que una gran dama podía hacer en su juventud dejaba de hacerlo cuando se casaba. En algunos casos, hay una relación muy clara entre el celibato, la virginidad y la capacidad masculina reconocida a las mujeres. En cuanto las mujeres entran en el circuito de la reproducción, sólo pueden ser valorizadas como madres. No es el sexo femenino la causa que explica el sometimiento de las mujeres sino el recelo ante su capacidad de fecundar y traer hijos al mundo" (Héritier; 2997:123)50.

Me gustaría finalizar esta sección del apartado, completando el testimonio que fue parcialmente citado anteriormente:

"En los jaripeos hay mucho ligue ahí ...después de que haces tu monta van las chavas y se te acercan. Con el puro hecho de que te vean ahí en el ruedo, ellas se fijan y te hacen la plática. Entonces pues tú les contestas y la ocasión se presta para bailar, después sí se presta la ocasión (para tener un acto sexual), pues les preguntas: ¿Sí quiere ir a un lugar más apartado?, iya sabes, el hombre llega hasta donde la mujer lo permite! ¿no?. Lo mismo ocurre en los gallos, con el hecho de estar en el palenque entrando y saliendo de la arena, ellas se te acercan. También cuando te ven (las mujeres) botudito, arregladito con sombrero y tu ropita vaquera, las muchachas se te acercan, les gusta. También si te ven alegre, que bailas y que te diviertes" (Entrevista con Roberto Delgadillo, habitante del barrio de la Asunción, Tepetlaoxtoc centro).

\section{Los palenques.}

Cada pueblo, según lo afirma el proverbio, ama su propia forma de violencia.

Clifford Geertz.

La identidad mexicana no se encontraría completa, si algunos de los primeros pensamientos no remitieran a la imagen del charro mexicano, por considérasele como el prototipo del mestizo mexicano desligado de los indígenas postcoloniales y de los negros del periodo colonial. De esa manera la imagen del charro mexicano se ubica al igual que el cowboy norteamericano o el gaucho argentino.

\footnotetext{
${ }^{50}$ Subrayado mío.
} 
La imagen del charro mexicano visto desde los ojos del cine mexicano, lo inscribió como un hombre que participa de los espacios públicos como son las cantinas, los lienzos charros y los palenques. Sin embargo, en la actualidad el hecho de ver a un charro desligado de un contexto festivo o no estar acompañado de algunos de los elementos simbólicos que lo caracterizan, como son: caballos o gallos, provocaría que el primer pensamiento fuera a la imagen del mariachi. Como lo comenta Jáuregui (2004):

"Sin embargo, el mariachi moderno, forjado en la Ciudad de México al amparo de los medios de comunicación electrónica, para ser tal debe vestirse de charro ...Aunque no sepan montar a caballo, ni domar una yegua bruta, ni echarle una mangana a una res; no conozcan los fierros de herrar y en su vida hayan disparado un revólver. Total... "el habito no hace al monje, pero le da figura"' (Jáuregui; 2004: 253)

Geertz en su ensayo: "Juego profundo: notas sobre la riña de gallos en Bali" realizó uno de los primeros acercamientos de la teoría antropológica sobre la temática de los palenques balineses. El autor enfatizó en las características de la arena de combate, parte de las reglas que intervienen en la parada ${ }^{51}$, los cuidados y las atenciones que tienen sus criadores, que serían vistos como fenómenos incomprensibles, sí no se toma en cuenta la cosmovisión del cuerpo masculino:

"...la concepción del cuerpo como una serie de partes separadamente animadas, los gallos son considerados como penes separables, que obran por su cuenta, órganos sexuales ambulantes con una vida propia ...está fuera de toda duda el hecho de que los gallos son símbolos masculinos por excelencia" (Geertz 1973: 343).

Al respecto, surge una parcial analogía cultural entre la pelea de gallos que describió Geertz y las que se desarrollan en los palenques mexicanos, aunque el principio y la finalidad sea la misma; es decir, un enfrentamiento imaginario entre sus respectivos dueños.

Con respecto a los palenques mexicanos, se pueden catalogar en dos tipos: los palenques ilegales y los legales. Debo argumentar, que ambos casos se rescata la figura del coliseo romano heredado tras la conquista española.

En lo que respecta a los palenques ilegales, su arena puede ser desde un círculo de personas que previamente acordaron el enfrentamiento hasta la transformación temporal de un terreno. En oposición se encuentran los palenques legales, que se caracterizan por haber realizado los trámites correspondientes ante la Secretaria de Gobernación (Segob), cubrir el costo $\$ 10,000.00$ en promedio para obtener un permiso especial52, además de dar aviso a las autoridades

\footnotetext{
${ }^{51}$ Término empleado para referir a la pelea de gallos o el enfrentamiento de los gallos.

${ }^{52}$ Ver Anexo 4, contiene: Noticia del 19 de enero 2007, donde la Suprema Corte de Justicia de la Nación (SCJN) autoriza el realizar "Carreras de caballos y peleas de gallos". Se adjunta uno de los formatos de la Secretaria de Gobernación (Segob), que otorga: "Permisos para pelea de gallos con rifas de números”.
} 
competentes. Otra de las diferencias es que los espacios elegidos para estos juegos masculinos van desde terrenos privados que temporalmente se han trasformado en la arena del palenque, pero con su respectivo permiso por escrito, hasta edificios construidos exclusivamente para este efecto, como lo es el Palenque de la Tradicional Feria del Caballo en Texcoco, Estado de México, por mencionar solo uno.

\section{El palenque en San Pablo Jolalpan, Tepetlaoxtoc.}

Las peleas de gallos se realizan en los siete municipios que comprenden el territorio del Acolhuacán Septentrional, es decir: Atenco, Chiautla, Chiconcuac, Papalotla, Texcoco, Tezoyuca y Tepetlaoxtoc. Con referente a este último, los palenques se efectúan principalmente en los barrios de San Vicente y el Calvario en Tepetlaoxtoc centro, en el Bo. de la Concepción y San Pablo en Jolalpan o en los pueblos de San Andrés de las Peras, San Pedro Chiautzingo y Santo Tomas Apipilhuasco.

\section{-La preparación-}

Algunos criadores de gallos cambian la alimentación de sus animales desde el momento en que desean participar en alguna contienda, sobre todo sí saben que asistirá un rival que por alguna razón se desea enfrentar en esta arena.

El entrenamiento de las aves de combate (gallos), se realiza una semana antes de la fecha convenida. Para este efecto, los criadores cuentan con una serie de jaulas de diversos tamaños y alturas que obligan a los animales a ejercitar sus patas y sus alas, se les separa de todas las hembras (gallinas) y desde un día antes al combate, los animales duermen en sus respectivas cajas de transporte y solamente salen para continuar ejercitándose.

Durante la semana previa, sino es que desde mucho antes, el criador se asegura de contar con todas las herramientas que necesitará en cada uno de los enfrentamientos, cerciorarse de que sus navajas se encuentren afiladas y que cuenta con el apoyo de dos personas de confianza que fungirán como soltador y amarrador del gallo. Además de invitar a sus parientes consanguíneos, compadres (parentesco ritual) y amigos para que apoyen económicamente, y a su vez, ganen dinero en efectivo sí triunfa su gallo.

\section{-El día del combate-}

En el barrio de San Pablo Jolalpan, existe un terreno de siembra que desde hace un poco más de cuatro años se utiliza en este día como palenque legal, sobre la base de los festejos de su santo patrón. En esta ocasión (año 2009), se colocaron una serie de pacas de zacate que formaron un rectángulo de aproximadamente $56 \mathrm{~m} 2$ de superficie. Alrededor de la arena, fueron 
colocadas sillas de plástico y un par de gradas en las bases del rectángulo y los servicios temporales del puesto de tacos y una cantina a un costado de la arena (Ver fotografía 13). Algunos de los contendientes que habían sido previamente invitados, a las once de la mañana comenzaron a recibir llamadas por teléfono que les indicaba que ya iba a comenzar el palenque. Cuando en realidad comenzó en el horario de costumbre; es decir, casi a las dos de la tarde. Horario en que ya había terminado la eucaristía del día domingo.

Fotografía 13 y 14
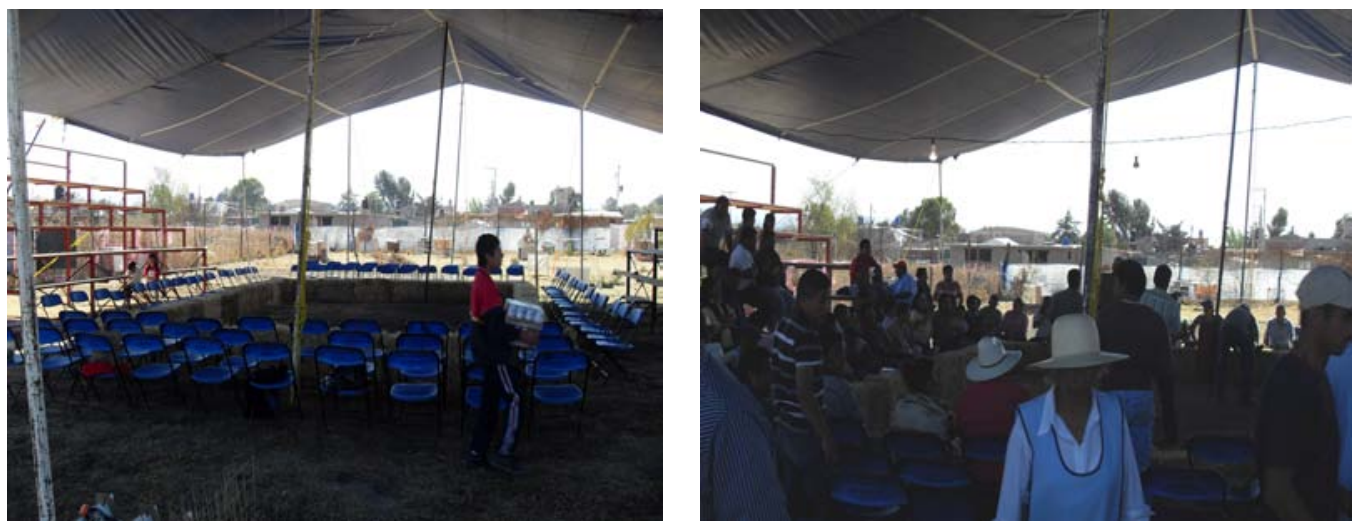

La arena del palenque.

En el lapso de tiempo que va desde el medio día hasta las dos de la tarde comenzaron a arribar curiosos, galleros y apostadores. Con la primera parada se abrió oficialmente el palenque. Los rivales pesaron a sus respectivos animales (ver fotografía 15), acordaron la cifra para ser apostada, el apuntador53 tomó nota de los nombres, preparó el reloj con los 15 minutos reglamentarios de cada pelea, mientras los galleros y sus asistentes (el amarrador y el soltador) realizaban su trabajo, los amigos y parientes del dueño juntaban el dinero de base para la afrenta. Cabe mencionar, que el dueño del gallo solamente recibirá y solicitará el apoyo económico de sus consanguíneos varones y compadres presentes para cubrir la apuesta base; muy difícilmente se aceptará el efectivo de los amigos o de los invitados tanto de los compadres como de sus hijos. Una vez que estaban preparados los animales, a cada uno de éstos se le presentó la mona ${ }^{54}$. Durante este tiempo algunos de los asistentes (la mayoría eran varones, había niños y algunas mujeres) masculinos, gritaban de todos lados la cantidad de dinero que deseaban apostar y el color del lado que representaría al gallo, por ejemplo: ¡Voy 100 al rojo!,

\footnotetext{
${ }^{53}$ Persona encargada de acomodar las peleas. Este es uno de los oficios temporales que aparecen en los palenques, pues a esta persona cada gallero debe pagarle $\$ 100.00$ por pelea, es decir, el apuntador por el simple hecho de llamar a los rivales se ganará \$200.00 por parada, más alguna propina voluntaria.

${ }^{54}$ Es un gallo de menor edad, estatura y peso que se utiliza para violentar al gallo que peleará.
} 
¡Van 50 al verde! o simplemente ¡100 ó 50 al rojo! y la respuesta que se esperaba era la siguiente: ¡Voy con verde! ó ¡Juega! Señalando y mirando directamente a la persona que ofreció la apuesta. Porque cito de Bourdieu:

"La división sexual está inscrita, por un lado en la división de las actividades productivas ...la división del trabajo del mantenimiento del capital social y del capital simbólico que atribuyen a los hombres el monopolio de todas las actividades oficiales, públicas, de representación, y en especial de todos los intercambios de honor, intercambios de palabras ...intercambio de regalos, intercambio de mujeres, intercambio de desafíos y de muertes" (Bourdieu; 2000:64).

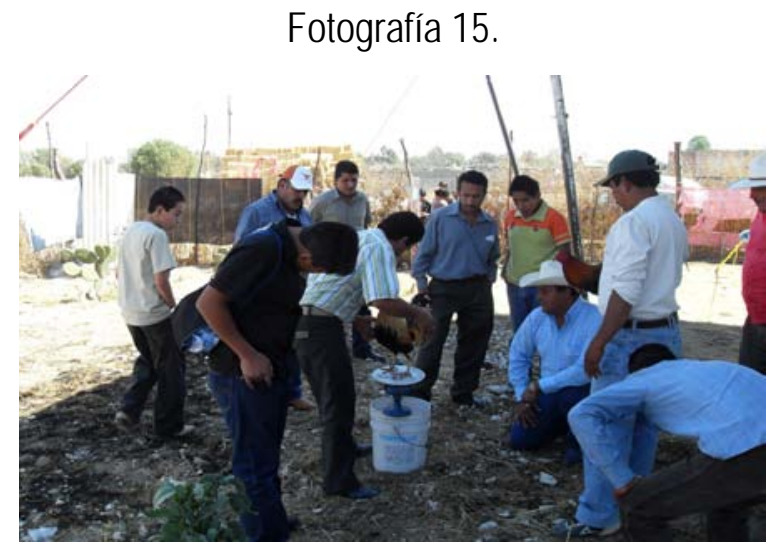

Comprobando el peso de los gallos.

Entre las cosas chuscas que pude observar, fue el caso de un par de hombres ebrios que apostaban una determinada cantidad a un gallo y la misma cantidad al contrario; de manera que aunque perdieran, su dinero se conservaba intacto. Lo trascendente es que festejaban sus victorias en los gallos, sin perder ni ganar ni un solo peso. Pero también, escuche comentarios como:

¡Quien apuesta por necesidad, pierde por obligación!

Para apostar en los gallos, hay que tener jhuevos!

Durante este día presencié hasta veinte peleas, en cada una de ellas el reloj comenzó a correr hasta que se cumpliera el tiempo reglamentario y se designe tablas (empate) 0 un adversario haya sido determinado como ganador. Cabe mencionar, que no hubo ningún empate en todo el día, pero sí más de 20 animales muertos que se arrojaban a las orillas del terreno. Y para garantizar que no hubiera trampas y que se cumpliera con el pago de la apuesta, el árbitro tiene la obligación de insertar por pocos segundos un limón en cada una de las navajas contendientes, dictaminar quién fue el vencedor, resguardar y entregar la apuesta base al ganador. A cambio de sus servicios, el ganador le podrá dar una propina económica. 
Las contiendas duran muy poco tiempo, pues literalmente los animales se despedazan entre si. En esta circunstancia lo que importa solamente es la suerte que designará a un ganador y un perdedor. Debido a las heridas tan profundas que sufren los animales, puede llegar el caso en que ambos gallos se encuentren tirados en el suelo. En ese momento el árbitro se dirige a los soltadores diciéndoles: ¡Tomen a sus gallos! En pocos segundos los soltadores revisan la gravedad de las heridas de su animal, si observan que está agonizando se le abre el pico y se le da respiración de boca a pico. Y por todos los medios posibles, tratan de que el animal se mantenga de pie o por lo menos la cabeza erguida. La labor del soltador finaliza en el momento en que el árbitro grita: ¡Tiempo! Y se vuelven a soltar a los gallos. Algunos de éstos recobraron su fuerza y terminan por cortarle la garganta al oponente y picotear a un cadáver, pero en la mayoría de los casos solamente se espera ver qué animal muere más rápido y primero, al respecto:

“...pues si un gallo puede andar, también puede luchar y si puede luchar, puede matar, y aquí lo que cuenta es cuál de los dos gallos muere primero. Si el gallo herido logra a su vez dar un golpe afortunado y el otro se desploma, el primero es el vencedor oficial aun cuando el mismo se desplome un instante después" (Geertz; 1973: 347)

Existieron varios casos en que algún gallo solamente había sufrido heridas superficiales, en estos casos sus dueños los dejaban descansar dos o tres combates seguidos para después enfrentarlos de nueva cuenta y se repetía la operación hasta que ese gallo muriera o su criador decidiera retirarse del juego. Debo comentar, que todos los gallos que se enfrentaron por segunda o tercera ocasión, terminaban muriendo en la arena o fuera de ella, ya sea venciendo a su contrincante o perdiendo frente a él.

Una vez que el árbitro designó al ganador, fueron pagadas todas las apuestas periféricas y se le entregó la apuesta base al vencedor. Porque cito de Geertz:

"...se pagan inmediatamente todas las apuestas. Aquí no hay ninguna clase de pagarés. Por supuesto, puede uno pedir dinero prestado a un amigo antes de hacer un envite 0 de aceptarlo, pero para ofrecer 0 aceptar una apuesta uno ya debe tener en la mano el dinero $y$, si uno pierde, tiene que pagar al punto, antes de que comience la próxima riña" (Geertz; 1973: 352)

Por su parte, el apuntador gritaba el nombre de los siguientes contendientes y preparaba el reloj con sus quince minutos reglamentarios.

Una de las diferencias que observé en los palenques de Tepetlaoxtoc en comparación con la pelea de gallos de Bali, son:

“...En los juegos profundos, en los que se apuestan grandes cantidades de dinero, lo que está en juego es algo más que las ganancias naturales: la consideración pública, el honor, la dignidad, el respeto, en una palabra ...el status. Pero el status está en juego 
simbólicamente, pues (salvo en algunos casos de jugadores viciosos arruinados) el status no se altera por la obra del resultado de una riña de gallos; es sólo, y eso momentáneamente" (Geertz; 1973: 356).

Y más adelante comenta: "...Pero realmente no cambia el status de nadie. Uno no puede ascender por la escala jerárquica por haber ganado en la riña de gallos; como individuo realmente no puede subir por ella. Ni tampoco puede descender por ella" (Geertz; 1973: 363-364)

Afirmaciones de la cuales difiero de sobre manera, porque sí es verdad que no se crítica a un hombre que perdió una pelea de gallos y mucho menos si cumple con el pago acordado, también es verdad que su prestigio como criador de gallos (su status social), decrecerá en la medida que pierda una pelea, luego otra y otra, en fin, el hecho de sus constantes derrotas lo marcarán metonímicamente como a una persona a la cual no se le debe comprar gallos de pelea, pues no sirven para el combate. Argumento que se generaliza en una red social tan cerrada como es el caso de los criadores de aves de combate del Acolhuacán Septentrional. Para apoyar lo anterior, rescato una entrevista indirecta que sucedió en el solar de un criador de gallos en el pueblo de Jolalpan cuando llegaron tres jóvenes del pueblo de San Jerónimo Amanalco, Texcoco a comprar gallos para unos juegos de compromiso que se realizaron los primeros días del mes de enero:

"...mira ahora que sean los juegos en San Jero, yo te acompaño y llevamos tres de los míos. En el momento que ese guey vea que vas conmigo no se atreverá a entrarle. ¡Pues sí yo le vendo! " (Anotación en diario de campo).

Lo que sí es verdad, es que el prestigio social del gallero vencido consecutivamente no decrecerá fuera de la red de galleros a la que pertenezca.

Si se devuelve un poco de tiempo a la frase: "...los gallos son considerados como penes separables, que obran por su cuenta, órganos sexuales ambulantes con una vida propia". Se podrá apreciar que Geertz logró demostrar la relación simbólica y por simpatía que asocia a los hombres con sus gallos de pelea, pues:

"La carnicería del reñidero no es una pintura literal de la manera en que se tratan los hombres, sino que es (lo cual casi resulta peor) una pintura de la manera en que, vistos desde un determinado ángulo, los hombres son imaginativamente" (Geertz; 1973: 367) En ese sentido, "...la riña de gallos reúne temas -salvajismo animal, narcisimo masculino, juego por dinero, rivalidad de status, excitación de masas, sacrificio cruento-, cuya principal conexión es su relación con el furor y con el temor al furor, al sujetar estas cosas a una serie de reglas que, por un lado las contiene y que, por otro, les permite desplegarse, crea una estructura simbólica en la que una y otra vez la realidad de su íntima significación puede sentirse inteligiblemente ...saber lo que siente un hombre después de haber ganado un reino y perdido su alma" (Geertz; 1973: 369). 
El hecho de que los hombres sean los únicos que culturalmente tienen permitido realizar representaciones simbólicas, derramar voluntariamente su sangre y encargarse de todos los ámbitos de la reciprocidad e intercambio, provoca que las cualidades que simbólicamente se les han atribuido a los gallos de pelea (al igual que los toros de lidia y / o de monta), terminen por ser apropiados y explotados por los hombres que están en contacto con ellos. En ese sentido y debido a la relación simpatética que existe entre el hombre con el animal, y viceversa, no resulta difícil entender: el por qué a las personas osadas, arriesgadas y valientes se les compara 0 se les identifica con estos animales. Para muestra presento dos narcocorridos mexicanos:

\begin{tabular}{|c|c|}
\hline "Mi orgullo ser sinaloense & "Soy michoacano hasta el tope \\
Lo digo donde yo quiero & Y me gusta la loquera \\
Estado de muchos gallos & La mota y el polvo blanco \\
Que se encuentran prisioneros & Y también la borrachera \\
Pero este gallo es más bravo & Traigo dinero de sobra \\
Les canta en su gallinero & Pa' amanecerme en la peda. \\
Tengan cuidado señores & \\
Andan buscando la muerte & Soy gallo de mucho gusto \\
El miedo no lo conozco & Cuando agarro la parranda \\
Para eso no tuve suerte & Rodeado de hembras bonitas \\
Soy cerca de Culiacán & Y mis cuates de la banda \\
Tierra de puros valientes" & Como todo michoacano \\
(Fragmento del narcocorrido: & No cualquier ruido me espanta." \\
"Clave privada" de la banda El Recodo). & (Fragmento del narcocorrido: \\
& "La Peda" del grupo Originales). \\
\hline
\end{tabular}

Siguiendo el mismo principio aparecen varios signos masculinos que en relación metonimica, remiten a la relación hombre-gallo o gallo-hombre, por ejemplo Ver fotografía 16.

Fotografía 16.

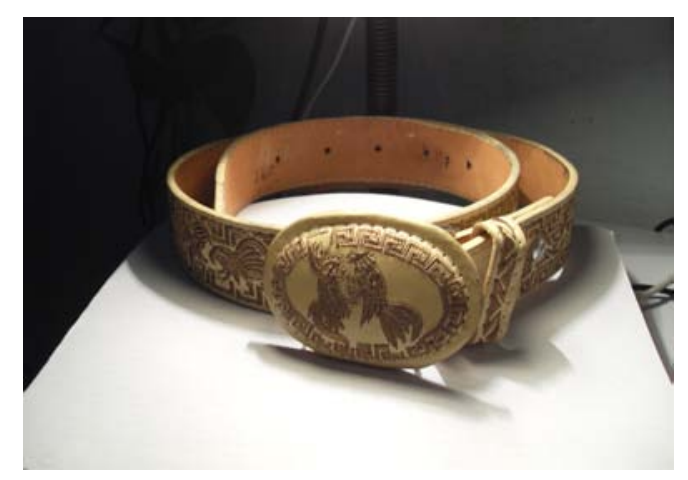

Cinturón charro con detalles bordados de gallos en combate.

Según lo expuesto anteriormente, rescato la siguiente premisa: ¿Los palenques pueden ser considerados como arenas políticas y simbólicas? Si tomo como referente a Roberto Varela 
cuando comentó que <<la participación es meramente otra forma de ver el poder >>, que los sustentó con una cita de Adams:

"La participación en general y la participación política en particular, aparece ser así un proceso más estructural que lo que se sugiere por una visión de que es meramente una forma en la que la gente influye en sus gobiernos ...Estudiar la participación es estudiar la estructura de poder en operación y, como las estructuras de poder, la participación es siempre recíproca" (Varela; 2005: 47).

Esto invita a recordar que la pelea de gallos es un enfrentamiento simbólico entre dos hombres, o mejor dicho entre la virilidad (penes) de dos hombres, donde uno de ellos termina por asesinar simbólicamente a su oponente. En otras palabras: el vencedor demuestra su supremacía viril sobre su contrincante y además, si se considera que el número de miembros que forman las redes galleras del Acolhuacán Septentrional es reducido, y que se conocen entre todos ellos se podrá entender que existe una rivalidad frecuente entre sus participantes (los criadores). Esta rivalidad, al no poder ser solventada con la violencia física, recurre a la violencia simbólica; es decir, la pelea de gallos. Es por eso, que cuando un criador desea solventar esa rivalidad que puede surgir por cualquier pretexto relacionado con el palenque preparará a un gallo en particular, lo cuidará y alimentará de manera especial hasta que llegue la oportunidad de enfrentarlo tal como lo pude comprobar en el barrio de la Concepción Jolalpan:

Me encontraba en la casa de un criador local, quien me explicaba sobre la forma en que se deben tomar a los gallos, las medidas y tipos de navajas, así como la manera adecuada de alimentarlos y la cantidad de dinero que se tiene que invertir en la manutención de cada animal. La plática y la confianza que existe, provocó que visitáramos la gallera para sus animales que se dedican exclusivamente a ser sementales (pisadores). Estando ahí, saco a un gallo de aproximadamente dos kilos y medio y me dijo:

¡Éste ya tiene dedicatoria! Es para un güey de Chiconcuac (dándole un beso al gallo). E inmediatamente me explicó (sin dejar de cargar al gallo), que existe un gallero del municipio de Chiconcuac al quien nadie había podido vencer, y por lo mismo, hacía alarde de sus animales y exaltaba su prestigio en los palenques. Entonces, el gallo que estaba en manos del criador de Jolalpan sería el que remediará la situación.

Es decir, quitarle la corona del palenque a uno para colocársela a otro, circunstancia que a su vez, crearía nuevos rivales en esta arena simbólica y política, pero eso sería solamente después de que la victoria fuera asegurada. 
Por último: ¿Qué imagen proyectaría alguna mujer que participe activamente en un palenque? En el municipio de Tepetlaoxtoc, no existe ninguna mujer que participe o haya participado en los palenques, pero la investigación logró conocer que en el municipio de Zumpango en el Estado de México, según comentarios, existen un par de mujeres (posiblemente señoritas), que apuestan en los palenques y fungen como la amarradora y soltadora de sus propios gallos. Las advertencias y gritos que se escuchan desde el público cuando van a participar estas mujeres, son de burlas, chiflidos y surgen comentarios como: $i A$ ver si no te corre! $O$ iNo te vayas a cortar!, pues, es bien conocido en el mundo de los palenques, que un gallo literalmente corre buscando una salida de la arena en el momento que el pánico se ha apoderado de él y en el segundo caso, se refieren a las navajas. Los comentarios que me hicieron al respecto de este fenómeno fueron que este par de mujeres nunca han ganado una sola pelea, a pesar de presentar animales muy finos y caros. Donde la forma en que amarran las navajas, es la única razón creíble y posible que argumentaron los dos galleros con quienes platiqué, para justificar las derrotas de sus oponentes femeninos.

A pesar que la investigación no pudo observar directamente este fenómeno difícilmente puede ser cuestionada su veracidad, según las propuestas de Héritier, pues cito:

"... Ios diferentes valores atribuidos a uno y otro sexo se convierten en escalas de valores igualmente diferentes y totalmente discriminatorias atribuidas a las tareas a las que afectan, y no a la inversa. No es porque la caza sea "noble" que los hombres cazan, sino porque los hombres son "nobles" y, por lo tanto, la caza también lo es. Éste es un fenómeno que continua observándose hasta nuestros días: una actividad masculina valorizada se desprecia cuando las mujeres acceden masivamente a ella ...Si las mujeres no pueden hacer correr sangre, tanto de los hombres como de los animales, la prohibición varía en intensidad según los grupos humanos." (Héritier; 2007: 323)

Por ende, se entiende la serie de burlas que se les efectúa a este par de mujeres, como una manera de "devolverlas" al campo de la reproducción y limitándolas como meras espectadoras en los palenques mexicanos, porque independientemente de su preferencia sexual, sí es que la hubiera socialmente están consideradas como mujeres. Quienes enfrentarán a su gallo contra el gallo de un hombre; es decir, el pene simbólico de un hombre contra un gallo que no tiene la capacidad de adquirir una clasificación simbólica al pertenecer a una mujer, o mejor dicho: un limen dentro del contexto ritual, donde el resultado final será un derramamiento innecesario de la sangre simbólica de ambas mujeres, porque:

"...asignan a las mujeres a lo privado, a lo interior, a lo doméstico, y a las tareas de mantenimiento concebidas como derivadas directamente de la asimetría funcional que hace que su cuerpo sea procreador y nutricio. Una constante como la prohibición 
relativamente general de hacer correr sangre pues ellas mismas pierden la suya. Eso podría acarrear derrames masivos por simpatía, dañinos para la fecundidad ulterior" (Héritier; 2007: 323-324)55.

\section{Las mayordomías de la siguiente semana.}

El lunes 26 de enero se festejó la mayordomía satelital de los cirios, que comenzó con una procesión del jardín hasta la capilla de San Sebastián seguida de su respectiva misa y posteriormente su rosario. Esta mayordomía se caracterizó por entregar en sus ofrendas una serie de ceras encendidas en el templo y también otras velas que no se habían ocupado. Durante esta mayordomía no hubo baile, castillo de fuegos pirotécnicos 0 algún espectáculo 0 danza regional que lo acompañará. Volviéndose el festejo más sencillo entre todos los que se realizaron en honor a San Sebastián.

Al día siguiente se festejó la mayordomía de las molenderas que nuevamente se caracterizó por una procesión de la casa de algunos de los mayordomos hasta la capilla de San Sebastián. Seguido de su eucaristía, en la cual el sacerdote pedía a Dios y a San Sebastian que bendijeran a todas las participantes de la mayordomía. Después se realizó su respectivo rosario y la mayordomía entregó como un tributo al santo, varias canastas de tlacoyos calientes que fueron repartidos y consumidos en ese momento, durante la noche se ofreció al santo patrón, un castillo de fuegos pirotécnicos y se presentó un trío que cantaba baladas románticas otorgándole al ambiente un sentido más familiar en comparación a las noches de las demás mayordomías, puedo comentar que fue durante esta noche que pude observar varias familias nucleares (matrimonios jóvenes, esposos y sus hijos infantes, parejas de la tercera edad) que disfrutaban de la velada, niños corriendo por la Calle de la Cruz y casi una nulidad de varones embriagados en comparación a todos los demás festejos.

La razón de que esta celebración fuese radicalmente diferente a todas las anteriormente vistas se debe a que esta es la única mayordomía que la realizan exclusivamente señoritas casaderas, esposas, madres y abuelas, que costean todos los gastos gracias a la venta de la masa y tlacoyos que realizan durante los fines de semana en el centro de Tepetlaoxtoc o en Texcoco. De esta manera, el espacio público fue secuestrado y empoderado durante 24 horas, por las mujeres que eran encabezadas por las mayordomas molenderas, donde literalmente existió una traslación del espacio privado, doméstico, propio de la mujer y sus infantes, al espacio público que es exclusivo de los varones.

Otro de los espacios que fueron temporalmente secuestrados son las casas en donde se dio el servicio del almuerzo, comida y cena a las integrantes de esta mayordomía. Porque, tuvieron la

\footnotetext{
${ }^{55}$ Cursivas mías.
} 
oportunidad de invitar directamente a sus familiares femeninos, comadres y amigas, vecinas 0 conocidas que ellas desearán sobre los deseos de sus respectivos esposos.

La razón de que todas las mayordomías, con excepción de los cirios, hayan entregado un castillo de fuegos pirotécnicos (Ver fotografía 17), se debe a que:

“...los dones de los hombres a los dioses se realizan mediante actos de ofrendas y mediante la destrucción de las cosas ofrecidas. Se sacrifican víctimas, se procura elevar hasta los dioses el olor del incienso y de los vapores de sacrificio y, eventualmente, se consume la carne de los animales sacrificados. Sacrificar supone ofrecer destruyendo lo que se ofrece" (Godelier; 1998:51)

Fotografía 17.

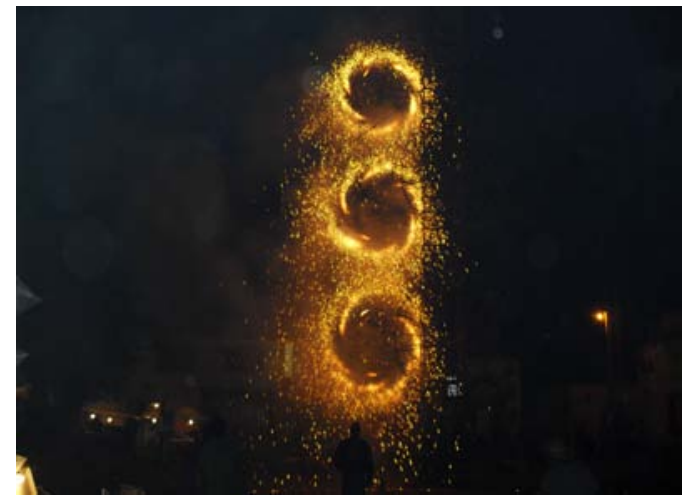

Castillo de fuegos pirotécnicos.

Para el día miércoles 28 de enero -como se comentó anteriormente-, se presentó la mayordomía satelital de los gañanes, que nuevamente se caracterizó por una procesión, rosario y una misa en la cual el sacerdote ahora solicitaba que las bendiciones se dirigieran a los miembros de esta mayordomía.

Solamente quiero enfatizar en dos diferencias sustentables que acontecieron a partir de este festejo: 1) Se realizó el primer simulacro de actividades laborables y 2) Aparecieron por primera vez las tlacualeras, que son la representación masculina de las mujeres que se dedicaban a preparar los alimentos en el tlécuil y a la venta de tlacoyos. Interesante situación que aparece exactamente al día siguiente del empoderamiento del espacio público por parte de las mujeres y que fueron encabezadas por las molenderas (vendedoras de masa y tlacoyos).

En relación al punto número uno, en el centro de Tepetlaoxtoc se desarrollan una serie de simulacros que corresponden a las mayordomías de los gañanes, tlachiqueros, albañiles y arrieros. En ese sentido, el simulacro trata de recrear las condiciones laborales que tienen que enfrentar cada uno de este tipo de trabajadores, sin importar la temporalidad y rentabilidad del oficio al que representan o se dedican; es decir, se pueden hacer representaciones de las 
actividades laborales propias desde el periodo porfiriano como es el caso de los gañanes, tlachiqueros y arrieros hasta los de la actualidad, como se presenta en los albañiles.

Con respecto al simulacro de los gañanes, puedo describirlo de la siguiente manera:

El nombre los gañanes, se debe a que de esa manera se les conoce a las personas que se dedican a los cultivos y a la siembra en este municipio. En ese sentido, se elige un terreno de siembra y se realizan concursos para ver quién de los participantes realiza el surco más recto y siembra más rápidamente, también se hacían concursos para ver quién apilaba más rápido el zacate. Lo que los jueces califican en este simulacro, son la velocidad y la calidad del trabajo realizado, se me comentó que anteriormente, el concurso se realizaba utilizando una yunta tirada por bueyes o un caballo, en la actualidad y con la introducción de la tecnología, el concurso ha sufrido algunas modificaciones incorporando tractores y vehículos motorizados, sin embargo, la tradición continúa pesando en algunos de los habitantes que organizan el simulacro y éstos obligan a que se haga de la manera tradicional, es decir con yunta 0 arado. Los premios que se otorgan al vencedor son herramientas de labranza para el campo y hasta un caballo de tiro; y no debemos dejar de tomar en cuenta que otro ganador de este concurso, es el dueño que prestó el terreno pues al finalizar el simulacro tendrá un terreno parcialmente rayado y sembrado.

\section{La mayordomía satelital de los tlachiqueros.}

"Al día siguiente (de la fiesta) el pueblo de Tepetlaoxtoc tenia un aspecto de desolación y de tristeza, como si una banda de cosacos hubiese entrado la noche anterior ...Las casas cerradas; la plaza y las calles, solitarias, llenas de basura ...uno que otro indio tlachiqueros, con su cuero y su acocote cargado en las espaldas, trotaba con dirección a la loma a raspar los magueyes" (Payno; 2004:729).

La participación de esta mayordomía en los festejos de San Sebastián comenzó a principio del siglo XX; aproximadamente en la década de los 20’s ó 30’s. Durante esta década, la actividad laboral del tlachiqueros estaba relativamente prohibida en el Estado de México lo que provocó que se volviera una actividad casi clandestina y propia de los traficantes de la época. La venta del pulque que obtenían los tlachiqueros se realizaba en la pulquería que está frente al jardín municipal del centro de Tepetlaoxtoc ${ }^{56}$, o en su defecto se tenía que transportar la bebida fermentada hasta las pulquerías de Texcoco. De las cuales la única que se conserva en servicio hasta la actualidad es la "Pulquería del turista" que está ubicada en el jardín municipal de Texcoco.

\footnotetext{
${ }^{56}$ La historia oral comenta, que era en esa pulquería donde se reunían los bandidos de Río Frío. Pudiendo citar un fragmento de la novela de Payno: "Evaristo (líder de una banda local y Capitán de rurales), no obstante esta mala disposición de la gente de Tepetlaoxtoc, que no ignoraba, por que Hilario, que los oyó, pocos días después se lo había contado, se presentó en el pueblo y los convidó, como tenía costumbre, a tomar un vaso del Tlamapa fino de la hacienda de don Manuel Campero” (Payno; 2004: 500)
} 
Para la década de los 70's, en Tepetlaoxtoc se continuaba con la actividad económica de raspar los magueyes que se ubicaban en los cerros del Ocoyo, Tlacaluca, Chonguiqui, Tetepayo o en los terrenos de la Loma y Tlaltel (donde se ubica la capilla vieja) cercanos al centro de Tepetlaoxtoc. Durante estos años no era extraño ver al arriero con varias mulas que cargaban sus respectivas castañas o cueros con pulque, pero esta imagen disminuía durante el mes de mayo, periodo que en Tepetlaoxtoc baja considerablemente la producción del aguamiel. En cambio, en el mes de diciembre y siguientes comienza a haber una alza en la obtención de la bebida.

Por otra parte, debido al crecimiento natural de la población y el arribo de migrantes de otros estados se han ido acabando las zonas y terrenos de los cuales anteriormente se obtenía el aguamiel. Como es el caso de los terrenos de la Loma, que en la década de los 70's, el municipio otorgó la concesión de apropiarse de un lote baldío con sólo el hecho de habitarlo sin que tuviera ningún tipo de servicio por el momento, pero condicionando la planeación urbana de tipo cuadrícula con ocho metros de calle y dos metros de banqueta; y también que una vez llegados los servicios, sus ocupantes tendrían que comenzar a pagar los impuestos que derogaban su predio. La oferta se extendió, arribaron y se instalaron de manera definitiva personas migrantes de los estados de Hidalgo, Guerrero, Puebla, Zacatecas, San Luis Potosí, Guadalajara y una minoría oriunda del mismo municipio.

Retomando, el festejo de los tlachiqueros en años anteriores, consistía en que bajaban los arrieros con sus mulas y castañas en el último jueves del mes de enero, con la finalidad de realizar una misa en suplica a San Sebastián para que fuera una buena temporada de producción y venta del pulque. Después de la misa, se procedía a obsequiar a todos los transeúntes una xoma de la bebida embriagante en honra al santo patrón. La cantidad de tlachiqueros fue aumentando con los años y el festejo coincidía con los periodos de mayor obtención de aguamiel en el año; es decir, los meses de diciembre-febrero. Lo que implicó la incorporación de cada vez más tlachiqueros y por ende pulque.

Con el tiempo se incorporó una remembranza de los emperadores prehispánicos y una representación de la forma tradicional de obtener el aguamiel y beber el pulque. Con referente a la primera, la historia oral comenta que la primera pulquería que se estableció de manera formal en el municipio y que continúa ofreciendo sus servicios en la actualidad, se encuentra ubicada en la calle Ocoyococ frente al jardín municipal. El primer registró escrito sobre esta pulquería se encuentra contenida en la novela de Manuel Payno "Los bandidos de Río Frío", de la cual puede ser citado: 
-En el pueblo de Tepetlaoxtoc- "Se construyó desde sus cimientos una grande pulquería, que por las figuras de Xóchitl y Netzahualcóyotl, pintadas con fuertes colores en la fachada blanca de la pared, llamaban la atención" (Payno; 2004:715)

Payno comentó, que estas imágenes fueron las que le otorgaron el nombre de: "Pulquería Xóchitl" a finales del siglo XIX y principios del XX. En la actualidad es popularmente conocida, como: "La Pulquería del Portón". Lo trascendente de este pasaje es que como parte ritual contemporáneo que realizan los mayordomos tlachiqueros, éstos solicitan la autorización a la diosa Mayehuatzin que es representada por "la reina Xóchitl del pulque" y que es acompañada por el rey del pulque (recordando la imagen de Nezahualcóyotl, que pudo adornar el umbral de la pulquería del centro). Tanto la reina Xóchitl como el rey del pulque, son un matrimonio miembros de esta mayordomía, pero para seguir el ritual propio de la costumbre, se disfrazan de reyes; es decir, usan una corona de cartulina forrada y una capa larga de un color vistoso.

En relación a la representación del tlachiquero, desde muy temprano se colocan varios magueyes en las siete calles que están a la redonda y cercanas al centro de Tepetlaoxtoc y la capilla de San Sebastián, el simulacro consiste en lo siguiente:

Después de la comida en honor a la mayordomía de los tlachiqueros uno de ellos que trae un mapache vivo, al que se le acerca al maguey. Inmediatamente aparece otro tlachiquero que le dispara al animal con un rifle de chispa (no le causa daño), se retira el animal (supuestamente muerto) y el tlachiquero se acerca con su indumentaria o herramientas y comienza sacar el aguamiel, la prueba y sí es de su agrado la comienza a guardar en las barricas, para que finalmente se reparta entre los asistentes en ese instante; es decir, el tiempo de fermentación se reduce cósmicamente en esos momentos, hasta que se obtiene el pulque que se regala en xoma.

La representación original indica que se tiene que realizar la misma operación en cada uno de los magueyes que se colocaron desde la mañana hasta llegar a la capilla de San Sebastián (en promedio son entre quince a veinte magueyes distribuidos -Ver fotografía 18). Tomando en consideración que muchos de los asistentes podrían encontrarse ebrios o imprudentes antes de llegar a la capilla, esa sería la razón por la que la eucaristía tiene lugar antes de la comida de los tlachiqueros, y no después. 
Fotografía 18.

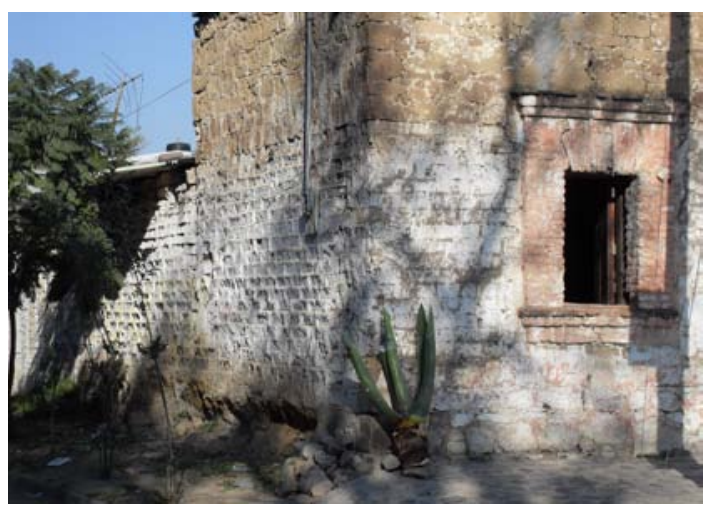

Maguey para raspar en una esquina de la calle Caxcantla en la orilla centro de Tepetlaoxtoc.

La representación se realizaba sin ninguna novedad hasta el año 2005 ó 6 . Año en que un joven (en ese periodo era menor de edad) se le ocurrió relatar en la Internet, su vivencia durante esta festividad. Su página puede ser consultada en la siguiente dirección electrónica: http://debnosus.blogspot.com/2007/01/la-feria-del-pulque.html

También por http://www.youtube.com Se presentan varios videos, fotografías y bailes sobre este festejo, con el título: "La feria del pulque en Tepetlaoxtoc".

Los medios masivos de comunicación y las noticias que comenzaron a circular sobre esta celebración provocaron que en los años subsecuentes comenzaran a llegar personas de distintas partes de la república con una sola idea en la mente:

¡Se regalan litros de pulque en Tepetlaoxtoc!

Y debido a que muchas personas desconocían si Tepetlaoxtoc era un barrio, pueblo o municipio y cómo se puede llegar a este sitio; comenzaron a escribirle al correo electrónico de este personaje, quien terminó por extender toda la información. En otros casos, los operadores de autobuses particulares vieron en esta festividad la oportunidad de un gran negocio lo que provocó viajes redondos especiales a Tepetlaoxtoc con motivo de la mal nombrada: "Feria del pulque". Resalta el caso de los habitantes de Veracruz, Querétaro, Hidalgo y Puebla que llegan hasta en dos camiones por estado y también un camión que transportaba habitantes de Toluca. Otra forma que se utiliza para llegar a Tepetlaoxtoc es en transporte público que se toma en las bases de Texcoco que a su vez, está comunicado con los municipios de Chimalhuacán, Chicoloapan y Nezahualcóyotl, sin olvidar la autopista Vía Lago, que comunica con la central camionera de la Tapo en el Distrito Federal. De esta manera, no es difícil de creer que llegan más de 5000 personas a visitar el municipio durante este día. 
Fueron tantos los problemas sociales que acarreó este festejo, que en el año 2007 se rumoraba que la festividad sería movida a otro día o se realizaría una semana antes, pero debido a que rompe con la sintonía cósmica que existe en el calendario festivo del mes de enero, no se hizo ninguna modificación a la fecha, sin embargo, el único cambio que se realizó fue que a diferencia de los años anteriores, a partir de este (2007), el pulque se vendería después de haber regalado una parte. Como una manera de poner un freno al abuso y al exceso que comenzaba a deformar la festividad.

Así, el número de detenidos durante el año 2007 fue de 750 personas, en el 2008 no se pudo llevar el registro, pero se infiere que fue una cantidad similar. Para el año 2009 llegaron a ser casi 900 detenidos según las referencias del cuerpo de policías municipales de Tepetlaoxtoc. Al respecto, los delitos más comunes eran: peleas, faltas a la moral (strip-tease y actos sexuales), infracciones menores contra la salud (consumo de drogas) y hacer necesidades fisiológicas, todos los anteriores en la vía pública. El castigo era una detención temporal con una multa de $\$ 350.00$ en todos los casos, excepto cuando había sido violencia con armas punzo cortantes 0 de fuego, en estos casos se remitían los asuntos a la procuraduría de Texcoco. La policía municipal de Tepetlaoxtoc en este día se apoyan de sus homólogos de toda la región del Acolhuacán Septentrional, excepto del municipio de Texcoco, quienes nunca acuden al llamado. Algunos miembros del cuerpo de policías municipales de Tepetlaoxtoc en el 2009, comenzaron a nombrar este día como: "El Pulquetón". En analogía al programa de apoyo a personas discapacitadas del Teletón.

\section{El último jueves del mes de enero (año 2009).}

A las nueve de la mañana comenzaron a llegar jóvenes estudiantes de diversas preparatorias y universidades, que inmediatamente se incorporaban a las cantinas temporales que vendían cervezas o micheladas a $\$ 30.00$ el vaso. Resalto el caso, porque esta fue la única celebración en la que observé que el consumo de bebidas embriagantes entre semana comenzará antes de las dos de la tarde, horario que era el promedio de consumo de la zona. Algunos tlachiqueros llegaron desde muy temprano con una o dos mulas y comenzaron la venta de un litro de pulque natural por $\$ 10.00$ y el litro de curado era de $\$ 15.00$ ó $\$ 20.00$.

Al paso de las horas y paulatinamente, las calles de Tlacaluca, Ocoyococ y la Calle de la Cruz se comenzaban a llenar hasta que se convirtió en un verdadero centro juvenil. Ver fotografía 19. 
Fotografía 19.

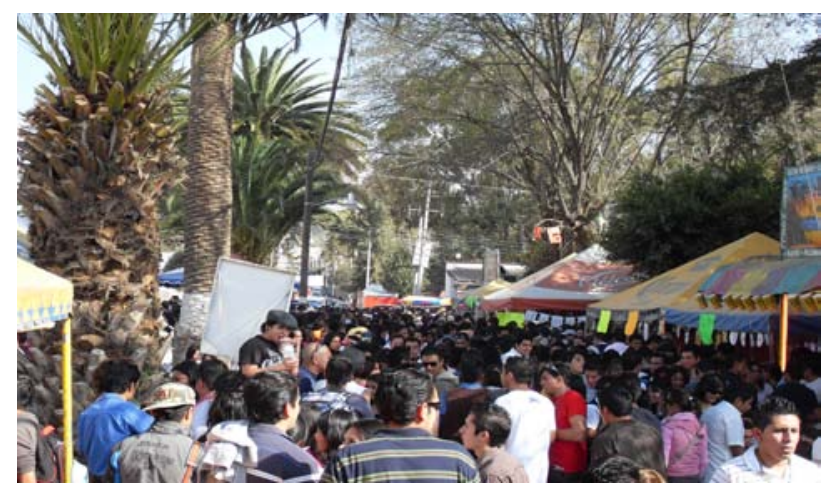

Calle Tlacaluca durante el día del tlachiqueros. La fotografía fue tomada a las 2:30 p.m.

Mientras llegaban los jóvenes y demás visitantes, los mayordomos se dedicaban a buscar sus reemplazos para el próximo año, ya fuera en los barrios de Tepetlaoxtoc o con algunos voluntarios. Para las tres de la tarde se había finalizado la búsqueda y todos los mayordomos tlachiqueros se dirigieron a la capilla de San Sebastián para que se realice la eucaristía. Una vez que finalizó, todos los mayordomos, los reyes del pulque, las tlacualeras, sus respectivos parientes consanguíneos y rituales, amigos y el conjunto de la banda clásica, se dirigieron a la casa del vecino que había donado la comida para la mayordomía. Detrás de toda esa comitiva, les seguían muy de cerca decenas de visitantes y turistas de Tepetlaoxtoc.

Durante el tiempo de la comida de los mayordomos, el consumo de alcohol (cerveza y pulque) continuaba sin ninguna novedad y cada vez aparecían más jóvenes ebrios, dormidos en los jardines y varios detenidos por diversos delitos.

A las cinco de la tarde se comenzaron a realizar las representaciones, pero debido a las fuertes demandas de los visitantes, los simulacros solamente se realizaron en cinco de los 16 lugares donde fueron colocados los magueyes. Por su parte, las tlacualeras, bailaban con todo varón que se pusiera enfrente o en su defecto lo sacaban a bailar, bebían con ímpetu y ocasionalmente se dejaban dar una nalgada por alguna persona ebria. Inmediatamente después, en la Calle de la Cruz arribaron los reyes del pulque, bailaron un poco en una tarima que se había colocado para el conjunto grupero de la noche. A los pocos instantes, llegó una camioneta con dos tinacos para el agua potable y sus ocupantes trataron de vaciar el pulque en un recipiente de plástico que tiene supuestamente una capacidad de 1300 litros y que representaría simbólicamente a las barricas para el pulque, este recipiente estaba al interior de una construcción temporal de madera que se instaló desde las ocho de la mañana simbolizado el tinacal para la venta del pulque, que en esta ocasión se regalaría. Ver fotografía 20. 


\section{Fotografía 20}

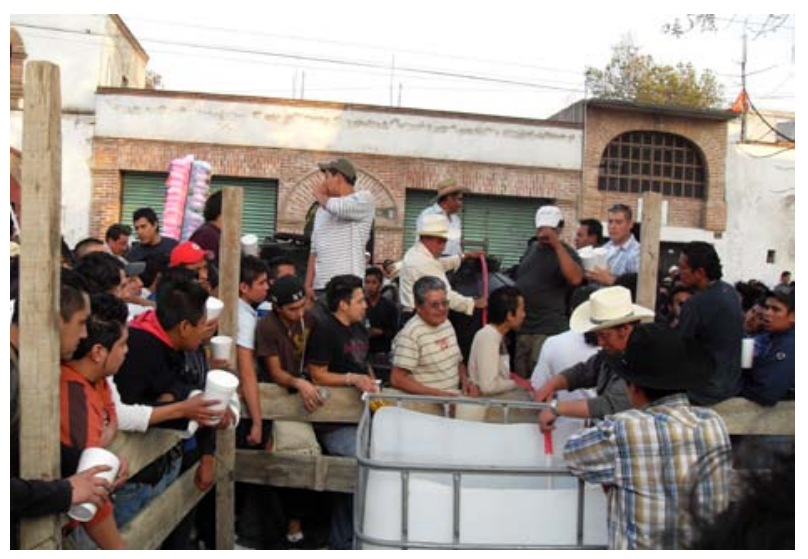

Los tinacos en camioneta y el Tinacal temporal en la Calle de la Cruz.

Debido a la lentitud con la que se descargaba el pulque en la barrica y las constantes demandas de los visitantes, quienes ya comenzaban a subirse a la camioneta para pedir pulque, provocó que los tlachiqueros abandonaran por completo su técnica y procedieron a sacar el pulque con cubetas y jarras.

Después de unos cuantos empujones y varios litros que terminaron en el suelo por no poder pasarlos al recipiente del tinacal, decidieron continuar sacando el pulque con las cubetas y repartirlo directamente a todos los que acercarán su vaso de unicel con capacidad de un litro. Este procedimiento fue el más eficaz y en menos de una hora se había terminado de regalar el pulque de ese año. Después, comenzaron a presentarse encima de la tarima varios grupos de jóvenes que habían llevado sus instrumentos musicales, en ocasiones eran acompañados con muchachas que bailaban al ritmo de la música que tocaran. Al mismo tiempo entre el público, comenzaban a presentarse casos de jóvenes (en promedio 20-23 años) que bailaban exaltando el contacto físico con sus parejas, otras se tocaban los senos y se levantaban su blusa por debajo de su sostén o se bajaban parcialmente los pantalones para mostrar el color de su ropa interior. De la misma manera se intensificó el consumo de alcohol, mariguana y otras drogas. También pude observar el caso de una señorita que en esa tarde-noche se besó con tres hombres en diferentes periodos de tiempo, aumentando el grado del contacto físico a medida que cambiaba de pareja, todas las anteriores, son situaciones que se pudieron realizar a plena luz del día, por el reducido número de agentes policíacos que no entraban a la Calle de la Cruz, y se limitaban a detener personas que cometieran alguna falta fuera de ésta.

En la noche se presentó un grupo de banda, se continuó con la venta de bebidas alcohólicas y en algunas calles obscuras alejadas del centro o de la capilla de San Sebastián se podían distinguir algunas sombras de parejas que parecía que sostenían actos sexuales. Lo mismo 
ocurría en algunos terrenos de siembra que se rentaban como estacionamientos públicos, pero al interior de los autos.

Por otra parte, los conflictos físicos entre varones se intensificaron sin importar el lugar y la hora, resalto el siguiente caso que pude observar directamente:

Eran como las nueve de noche y yo me encontraba en la calle de Tlacaluca frente a la presidencia municipal. En ese preciso momento, se estaban liberando a tres jóvenes con distintivos anarquistas que tenían en promedio 17 a 22 años de edad. Cuando los tres se encontraron fuera de la presidencia y con sus respectivos cinturones en las manos, pues al ser detenido se indica a la persona que se desprenda de el, como parte de la rutina. Uno de ellos (el primero que salió), sin motivo aparente alcanzó a una pareja de transeúntes y comenzó a golpearlos, sus dos amigos le siguieron a la acción, inmediatamente, algunos miembros del cuerpo de policías municipales salieron de prisa, deteniendo a los agresores y reteniendo a la víctima. La muchacha que acompañaba a la víctima abogó por su pareja, quien fue liberado incluso antes de ser remitido a las instalaciones de la presidencia. En el caso de los agresores, tardarían unas horas más en salir o se quedarían detenidos por 24 horas al no poder pagar nuevamente la fianza de $\$ 350.00$.

\section{Interpretación.}

Como lo comenté anteriormente, varias personas que habitan en los barrios aledaños al centro de Tepetlaoxtoc no participan directamente de las fiestas satelitales que se realizan en honor a San Sebastián; en cambio, optan por ver la programación de la televisión pública o de cable 0 una película en su DVD, navegar en la Internet y / o dedicarse a escuchar la radio, todo desde la comodidad de su hogar. En oposición a salir a las calles de su pueblo, que en esos días se convierten en espacios de tránsito intersticiales y de conflicto.

La festividad de los tlachiqueros, se caracterizó por una nula participación de los habitantes del municipio y sus comunidades, en comparación al número de visitantes provenientes de todas partes de la republica y de otros países. La razón se puede encontrar en la dinámica social que caracteriza a los pueblos; es decir, los fuertes vínculos de relaciones de parentesco consanguíneo y / o ritual aunado a un conocimiento por años sobre las costumbres de la familia de origen de un individuo plenamente identificado (o mejor dicho una persona -en términos de DaMatta-). Lo que implica, que si un habitante (varón) de algún barrio del centro o de algún otro pueblo de Tepetlaoxtoc, se le viera embriagándose en esta festividad, provocaría una fuerte crítica a su familia de origen, pues: 
“...No, el pulque del jueves (día de los tlachiqueros), no. Ese solamente lo beben los nacos del distrito, se le da a toda la nacada cuando vienen.

Lo voy invitar con un señor compadre de mi hijo, ese sí tiene del bueno, ahí sí" (Comentario de Don José Delgadillo -padre- a su licenciado quien lo había invitado a la fiesta de los tlachiqueros).

Porque no se juzgaría que bebiera pulque, sino que se excediera a sabiendas que ese pulque está considerado como el más corriente por varios de los vecinos del municipio. Por ende, el hecho de que este varón se exceda con un pulque gratuito descenderá automáticamente el status social de su familia extensa y nuclear, al suponer que no tiene el capital económico suficiente para comprarse un litro de un buen pulque 0 alguna otra bebida alcohólica. Pero las cosas se complicarían más, si se tratará de una mujer que fuera vecina de alguna comunidad del municipio o de algún barrio del centro de Tepetlaoxtoc y fuera vista bebiendo en exceso o con su propio vaso en la mano. Situaciones que en la cultura tepetlaoxtoqueña no están bien vistas y por lo tanto permitidas.

En cambio los hombres pero principalmente las mujeres que arriban al municipio con pretexto de la mayordomía de los tlachiqueros, hacen uso del carácter de individuos o anónimos que los y las caracteriza en sus espacios urbanos de origen ${ }^{57}$. Circunstancia que se refuerza durante la mayoría de los casos en este municipio, al no tener ningún vínculo parental con ninguno de los habitantes o con los demás turistas pulqueros. Lo que provoca que las calles de Tepetlaoxtoc se conviertan temporalmente en zonas de tránsito, propia de los $\langle<$ no lugares $\gg>$, pero que permiten un anonimato casi total para ambos géneros ${ }^{58}$, el consumo excesivo de alcohol, posible acceso a alguna droga, la nulidad de la autoridad paterna o materna y la formación de relaciones amorosas ocasionales o el exceso de contacto físico entre los participantes. Son sólo algunos de los elementos que caracterizan a estas calles durante esta celebración, pero ¿Por qué razón los jóvenes tienen relaciones sexuales previas a una alianza (matrimonial o una unión consuetudinaria mesoamericana), y sobre todo en la vía pública, como fue el caso durante el desarrolló de esta festividad?

En todos los periodos históricos han existido casos en que las parejas de jóvenes han tenido relaciones sexuales antes del matrimonio. Por eso es de prioridad para los grupos poder proteger la virtud (virginidad) de las señoritas frente a los depredadores sexuales (los varones).

\footnotetext{
${ }^{57}$ Retomo de DaMatta: “Aquí, un punto decisivo es que el “¿Sabe con quién está hablando?” desenmascara situaciones y posiciones sociales. Así ...en una ciudad pequeña no se usa esa forma de fuga hacia el anonimato simplemente porque el anonimato no existe. Lo mismo sucede en las sociedades tribales, donde la posición en una familia, el hecho de poseer ciertos conjuntos de nombres o de pertenecer a determinado linaje definen a la persona como poseedora de ciertas prerrogativas sociales.”(DaMatta; 2002: 224-225).

${ }^{58}$ Me refiero a los grupos de amigos que arriban o a los vecinos que se pueda encontrar de manera ocasional.
} 
En ese sentido y en el ámbito mesoamericano se incita a los hombres a tener varias vivencias sexuales antes del matrimonio, porque:

"...un hombre debe llegar al matrimonio sabiendo" (anotación de diario de campo).

O “...el hombre llega hasta donde la mujer lo permite” (anotación de diario de campo).

En cambio, las mujeres son altamente reprimidas y vigiladas para evitar que se aprovechen de ellas, principalmente cuando comienzan a mostrar los primeros cambios físicos propios de la pubertad. Y probablemente, en respuesta a la fuerte represión que se mantiene sobre la joven durante este periodo de cambios hormonales, y que es evidente al prohibirle salir sin ser acompañada, en un horario flexible, tener un novio, recibir regalos de los jóvenes, etc. incita a las señoritas de la pubertad, a mantener relaciones sentimentales a escondidas (fuera de la vigilancia de los padres) con varones que gozan de cierta libertad social para cortejarlas, y si a esta probabilidad se le aúna la facilidad que tienen las mujeres para conseguir distintos tipos de anticonceptivos en la actualidad, se puede plantear el siguiente supuesto: El desconocimiento de los padres sobre los deseos y planes de sus hijos, aunado a la incapacidad de concebir que los jóvenes tienen vidas sexuales a su corta edad, y la fuerte represión que se someten a las señoritas para relacionarse ocasional o amorosamente con los varones, implica que los jóvenes en general, consideren al noviazgo como un espacio propio que les permite dar a conocer sus deseos, pasiones, intereses y sentimientos, que no pueden ser expresados en cualquier circunstancia o a cualquier persona. Sin olvidar, que el noviazgo o / y las relaciones amorosas ocasionales son vistas como espacios que están desligados de las obligaciones que le impone su grupo, como: ir a la escuela, tener buenas calificaciones, trabajar, llegar a horas determinadas al solar, respetar la división social del trabajo y mantener el honor de la familia. Por ende, al ser un espacio construido por y para la pareja, que está desligado de la influencia de los padres, los jóvenes terminan por tener relaciones sexuales a sus cortas edades, sobre la base de: 1) Mantener esa relación sentimental o ese espacio de expresión exclusiva de la pareja, 2) "La incapacidad de negociación" que tienen las señoritas para elegir el momento, tiempo y lugar para realizar el acto sexual, 3) La "confianza" de que la joven no se puede embarazar o que a su edad no le corresponde tener este tipo de problemas, 4) El uso de anticonceptivos, y 5) Los constantes bombardeos de los medios masivos de comunicación que incitan a explorar ese mundo prohibido, pero codiciado por el hombre. Y si esos elementos se conglomeran con las condiciones anteriormente descritas de la fiesta de los tlachiqueros, se podrá entender el por qué hay tantos casos de liberalismo sexual ejercido por las mujeres presentes. 
Al día siguiente desde temprano se comenzó con el aseo del lugar, había basura en todos los rincones del centro y calles aledañas, para agilizar la labor, algunos vecinos limpiaron sus respectivas entradas y los barrenderos municipales solían recoger todos los desechos (que en su mayoría eran vasos como se habría de suponer). Horas antes había comenzado la mayordomía de los comerciantes, quienes fueron a entregar algunos arreglos florales a la imagen de San Sebastián y para no interrumpir la limpieza del pueblo, decidieron ir al solar donde se les otorgaría un desayuno.

En la Calle de la Cruz, se habían instalado algunas mantas y días antes se realizaron una serie de pintas que anunciaban el horario en que se presentarían distintos grupos musicales, que tocarían banda, rancheros y estilo duranguense. Además, al medio día se comenzaba a instalar el castillo de fuegos pirotécnicos.

La tradicional eucaristía en honor a la mayordomía en turno se celebró a las cuatro de la tarde. Inmediatamente, los mayordomos, sus familiares, amigos y vecinos acompañaron al santísimo al solar donde se ofrecerá la respectiva comida.

Fue hasta las nueve de la noche que comenzó a tocar el primer conjunto grupero, seguido de una banda musical y un comediante. Mientras se desarrollaba el espectáculo, varias parejas de personas de diversos pueblos se dedicaban a bailar, algunos otros varones ingerían bebidas alcohólicas y una minoría se dedicó a platicar de algún tema del momento 0 a saludar a algún viejo conocido o familiar que se había encontrado fortuitamente. Este hecho ameritaba que se brindara por la ocasión. A las once se encendió el castillo de fuegos pirotécnicos y la presentación de todos los conjuntos finalizó hasta la media noche, no sin antes recordar que los mayordomos comerciantes habían corrido con todos los gastos de su presentación.

A pesar de que esta mayordomía no presentó ninguna danza regional, no realizó ningún simulacro que caracterizara su labor y que tampoco efectuó ningún rosario, dictarían que fue la mayordomía más sencilla o deslucida que se presentó en honor al santo patrón. Sin embrago, la cantidad de artistas musicales y el baile de carácter público que se efectuó, solamente puede ser comparable con la festividad del 20 de enero, a pesar de faltar los otros dones que también se pudieron haber entregado y esto devuelve el prestigio.

\section{Los albañiles.}

Al día siguiente se presentó la mayordomía de los albañiles, ésta al igual que todas las anteriores -con excepción de la mayordomía de los comerciantes-, se caracterizó por entregarle a San Sebastián: una misa en la que resaltaban el apoyo de estos mayordomos, en la tarde se realizó un rosario y su comida. Para la noche, se efectuó un simulacro sobre sus actividades 
laborales, se presentó un conjunto musical y banda clásica que invitaban al baile a los asistentes y, se encendió el castillo de fuegos pirotécnicos.

Durante el desayuno, comida y momentos antes del desarrollo del simulacro, fue más evidente (a diferencia de las demás mayordomías) que las redes de parentesco (por colateralidad, alianza o compadrazgo sacramental o no sacramental) se hicieron presentes. Pues los mayordomos (que también eran los maestros constructores) y presentaban a sus distintos parientes masculinos que también se dedicaban a la albañilería, como una suerte de que en algún momento se les invitará a participar laboralmente en una obra o viceversa; es decir, que el pariente invitará a los lugareños sí es que se encontraban temporalmente desempleados. Situación que cobraba su importancia, en la medida que el pariente masculino por alianza 0 compadrazgo residía en otro municipio que estuviera cercano a Tepetlaoxtoc.

En la noche se realizaron varios concursos, como: Qué maestro constructor... A) Dirigía más eficazmente a sus ayudantes (chalanes o macuarros) para preparar la mezcla, traer un determinado número de herramientas, acarrear la mayor cantidad de arena, B) Tomaba más cervezas tipo caguamas y podía hacer movimientos bruscos (por ejemplo correr), C) Mandaba a realizar la pared más alta, ancha y derecha posible.

También se realizaron concursos para los chalanes, como: Qué grupo de chalanes que representaban a algún maestro constructor, aguantaba más bultos de cemento, quién traía más tabiques, etc. que son actividades muy propias de su trabajo. La premiación para todos los maestros constructores que participaron, consistió en la cantidad de arena o bultos de cemento que sus chalanes acarrearon, pues al finalizar cada concurso se podían conservar. Como regalos adicionales y para marcar una diferencia entre los ganadores y perdedores, se obsequiaban palas, cucharas de albañil, metros, plomadas y niveles, acompañado de un reconocimiento público para el maestro constructor. En el caso del concurso de construir el muro más alto, los maestros se repartieron desigualmente un millar de tabiques rojos, pues la cantidad dependió del número de ejemplares que pudieran apropiarse en un tiempo determinado sus respectivos chalanes.

Cabe mencionar algunos detalles: A) Las tlacualeras bebían, bailaban, brincaban a los brazos y abrazaban de los chalanes y del maestro constructor, B) El equipo (maestro y chalanes) que ya habían concursado y ganado, se les invitaba a ya no participar en el siguiente simulacro para que todos se llevaran algún premio, C) Los jueces se valían de modelos de madera que eran representaciones metafóricas exageradas de sus herramientas de trabajo, como era: una cuchara de albañil de un metro y medio, una plomada o un nivel de ochenta centímetros y una pala un poco más grande de lo normal, que servían para verificar el cumplimiento de las 
condiciones impuestas en cada prueba y D) El sitio elegido para las demostraciones laborales fue el mismo en donde se había instalado el tinacal temporal unos días antes.

\section{La mayordomía satelital de los arrieros}

"Mi abuelo era miembro de la banda de los de Río Frío, él traficaba pulque a Texcoco" (Testimonio de la Sra. Yolanda Delgado, oriunda del barrio de la Santísima, Tepetlaoxtoc centro).

En el desarrollo de la novela de "Los bandidos de Río Frío" en diversas ocasiones se hace referencia al entonces pueblo de Tepetlaoxtoc, su gente, fiesta, oficios, cuevas, pulquería, descripciones muy detallas de las calles 0 algunos edificios que coinciden parcialmente con la actualidad. Pero de los elementos más trascendentes de este relato, fue el simulacro del asalto a la diligencia que se describe en el capítulo XIV: "Terrible combate en Río Frío", el cual citaré parcialmente para después compararlo con el simulacro que desarrolló la mayordomía en el año 2009:

"Evaristo ...fue a encontrar Hilario con una parte de los soldados que formaban la escolta. Montó a caballo y, más bien corriendo que galopando, llegaron todos sin novedad al rancho de los Coyotes, donde estaba el resto de la escolta y además muchos de los valentones de Tepetlaoxtoc.

-Amigos -les dijo Evaristo, ya que se había lavado y cambiado el traje mojado y sucio de carbonero por el vistoso y plateado de capitán de rurales-, hoy, en vez de escoltar, tenemos que asaltar a las dos diligencias que se reúnen a la venta de Río Frío rifarnos.

...-Como usted quiera -respondieron a coro los de Tepetlaoxtoc-, aquí estamos para

...Hilario se puso a reflexionar y a contar a los presentes.

-Treinta y uno que están aquí, cinco en el Agua del Venerable y diez que andan en el camino de Ayotla a la venta, son en junto cuarenta y seis, y el capitán y yo; como quien dice cincuenta hombres, pues nosotros valemos por dos y hasta por cuatro

...-Sobra con eso -dijo Evaristo-. Oigan bien lo que les voy a decir: quiten las balas lueguito a las paradas de cartuchos, y vámonos a galope y por las veredas para llegar a tiempo. La mitad seremos ladrones que asaltarán las diligencias luego que los pasajeros estén montados y el cochero haya remudado las mulas, y la otra mitad seremos escolta que defenderá las diligencias y atacará a los ladrones; pero todito de mentiras, muchos balazos sin bala, muchos sablazos y caballazos sin lastimarse. Los ladrones al fin serán vencidos y escaparán a uña de caballo, y la escolta ganará, de modo que los pasajeros vean todo y puedan dar razón; en seguida me iré yo a México a dar parte y sacar los haberes, pues la aduana de Texcoco no tiene ni un real, y nos debe como quien dice, dos meses que se cumplen pasado mañana, y ya saben que se ha vivido de lo que nos dan los pasajeros. Con que ya saben, todito de mentiras, pero bien hecho.

Los de la escolta y los de Tepetlaoxtoc percibieron la malicia del capitán que trataba de darse importancia sin exponer el pellejo; pero sin sospechar siquiera el verdadero motivo de este simulacro, prometieron que se portarían bien y que el capitán quedaría contento, y riendo a carcajadas, picando los ijares de los caballos y haciéndolos caracolear y saltar, partieron a galope tendido, tomando las diferentes veredas que conocían con los ojos cerrados y que iban a terminar en el camino real.

....No bien habían subido los cocheros al pescante, y los postillones se disponían a soltar el tiro, cuando se escucharon por el monte unos disparos de fusil; un grupo de hombres a caballo salió del bosque, marcó el alto y, rodeando los carruajes, notificaron con las rasposas 
palabras de costumbre a los pasajeros que entregarán sus relojes y dinero y se dispusieran a bajar y abrir sus baúles y maletas.

Pero no pasaron diez minutos sin que bajara del lado opuesto otro grupo numeroso, a cuya cabeza se presentó Evaristo gritando con una voz estentórea:

-¡Aquí está la escolta del gobierno, grandísimos collones, y no tengan cuidado, señores, que aquí esta Pedro Sánchez!

Y sonó una descarga cerrada de tercerolas y pistolas sobre la diligencia, de donde salió un solo grito desgarrado y lastimero, como de muerte, que lanzaron los pasajeros, que creyeron que era el último día de su vida" (Payno; 2004: 543-545).

Preámbulo y horas antes del simulacro de los arrieros (1 de febrero 2009).

A medida que se acercaba el final del ciclo festivo de San Sebastián, algunos de los habitantes del centro o de otros pueblos de Tepetlaoxtoc movían sus redes sociales para conocer quién les podría prestar, rentar o vender un caballo. De la misma forma, entre los agentes no humanos que comenzaron a circular entre algunas redes sociales (parientes y amigos o conocidos), fueron cajas de parqué, armas de fuego cortas y largas, indumentaria de manta, espuelas y sillas para montar. En lo que refiere a las armas de fuego y sus respectivos cartuchos, se obtenían directamente en el Distrito Federal o en los solares de algunos oriundos de los distintos pueblos del municipio. Donde la única forma de acceder a estas redes sociales, era conociendo directamente al vendedor o alguna persona que compartiera su red social, es decir: amigo, compadre sacramental o no sacramental o un pariente masculino por alianza o filiación. Asimismo, el pago por el agente no humano podría ser de contado o llegar a un acuerdo para la liquidación en distintos pagos, todo dependía de la confianza y cercanía que se mantuviera estructuralmente con el vendedor. Lo que sí, la entrega del arma, parqué, montura o caballo vendido era inmediata y sin trámites.

En la tarde de unos días precedentes a la mayordomía de los arrieros, en un barrio del pueblo de Jolalpan se escucharon varias ráfagas al aire. Y surgió el siguiente diálogo entre dos de los cuatros asistentes:

Persona 1: "Están soltando descargas"

Persona 2: "Y son continuas ...¿Quién estará estrenando juguete?"

Persona 1: "No sé, pero ya lleva un buen rato"

Persona 2: -Dirigiéndose a mí- "!Aquí estrenan juguetes a cada ratoj"

Cabe mencionar que mientras se desarrollaba este diálogo, el tirador soltó tres cargas más de parqué. Por la frecuencia de los disparos en tan corto tiempo, solamente orilla a pensar que se trataba de un arma automática.

Cuando llegó el día esperado, se pudo observar algunos lugareños que liquidaban el último pago para la renta de su caballo. Y logré escuchar el siguiente comentario por parte de un rendador en el centro de Tepetlaoxtoc: 
"...!Pues sí hasta le dije que me avisará con tiempoj, tenía todo esto lleno"

(Anotación en el diario de campo).

Refiriéndose al espacio del patio de su solar que había acondicionado para hacer corrales temporales y emprender la renta de caballos para esta ocasión.

Desde las diez de la mañana, en las calles de Tlacaluca (a pesar de haber cervecerías temporales), Jardín, Tlaxcantla, Calle de la Cruz, Xolaltenco y Fray Pedro Duran (Ver mapa 1), se podían apreciar bandas de jinetes que disparaban algunas ráfagas de fuego, bebían tequila 0 mandaban al caballo para realizar alguna demostración ecuestre (Ver fotografía 21 y 22). Como una suerte de víspera de la representación de los Bandidos de Río Frío que tendría lugar hasta las cinco de tarde, en las calles de Jardín y Tlaxcantla.

Comento, que también había niños (varones) que disparaban sus armas de fuego, bajo la supervisión de su padre, observé el caso de tres señoritas que montaban en esta mayordomía, que pudieron o no ser oriundas de este municipio, pero nunca dispararon alguna arma.

Fotografía 21 y 22.
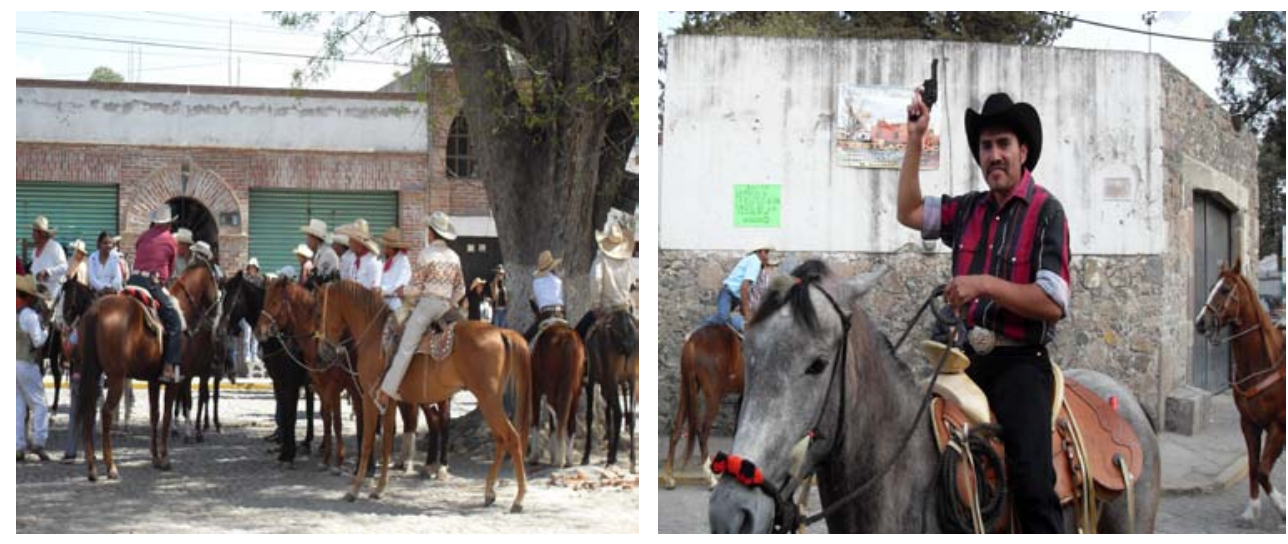

Algunos participantes de la mayordomía de los arrieros.

Al fondo del lado izquierdo de la fotografía no. 21, se puede apreciar una señorita montando durante esta fiesta. En la fotografía no. 22: Miguel Ángel Guerrero, oriundo del municipio de San Andrés Chiautla.

A medida que las horas se aproximaban al medio día o las primeras horas de la tarde, vislumbraban más jinetes provenientes de otros municipios vecinos del Acolhuacán Septentrional (principalmente de San Andrés Chiautla, Chiconcuac y en menor medida Texcoco) y también del estado de Tlaxcala. Algunos de ellos, habían montado una o dos horas antes de llegar a los límites políticos del municipio de Tepetlaoxtoc, y de ahí, continuaban su marcha hasta llegar al centro. En otros casos, simplemente montaron desde la cercanía de algún pueblo de la entidad. Resalta el caso de la comunidad de Jolalpan, pues un buen número de los jinetes que asistieron eran vecinos u oriundos de alguno de sus barrios. 
A eso de la una o dos de la tarde en la calle de Tlacaluca, comenzaron a abundar más jóvenes jinetes (de 20-24 años de edad) que hacían demostraciones ecuestres, ordenaban que el caballo bailará, caracoleará o en ocasiones hasta que se acostará para que el jinete se sentará en él. El fenómeno causo admiración, por la corta edad de los varones, su apropiada indumentaria vaquera y el control que ejercían sobre el caballo. Por ende, existieron varios casos de señoritas casaderas y hasta extranjeras que visitaban la entidad, que les solicitaron una vuelta en su caballo por el centro del municipio. Esta forma de interacción que se daba gracias al caballo (agente no humano), permitió en algunos casos un constante intercambio de besos, números telefónicos y sonrisas entre los actores sociales.

-Danza de los serranos-

Mientras el tiempo transcurría, en la Calle de la Cruz se presentaban la comparsa de los serranos, que fue el último grupo de danza regional que se exhibió como tributo a San Sebastián Mártir.

Los miembros de la comparsa de los serranos, se caracterizaban por traer un palo adornado con listones de varios colores y cascabeles que el conjunto fungiría como bastón de viajero, traje de manta, sombrero de paja, huaraches, morral y un huacal a sus espaldas que simbolizaba una suerte de valija que porta todos los trastes e instrumentos y herramientas que necesitará el peregrino en su trayecto. Así mismo, algunos de los danzantes tenían colgados ciertos animales (disecados o de peluche), como eran: conejos, ardillas, mapaches, tlacuaches y ratones. Bestias que simbolizan de manera metafórica a todos los que se pueden encontrar en su trayecto por la serranía. Ver fotografía 23 y 24.

Fotografía 23 y 24.
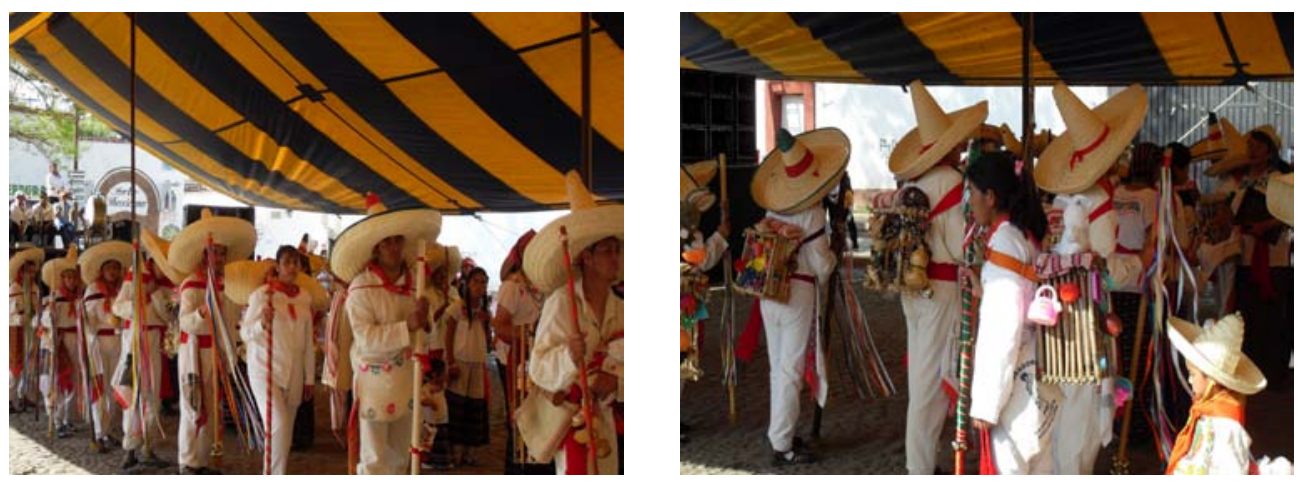

Miembros de la comparsa de los serranos

Observar el conejo blanco de peluche que carga la niña de la fotografía 24.

Cabe mencionar, que en las danzas regionales de los vaqueros, sembradores, serranos y las sembradoras participaron infantes de ambos géneros, como se puede verificar en la fotografía 
no. 24. Pero fue solamente en el baile de los serranos, cuando pude apreciar a varones cargando a sus bebes vestidos a la usanza y colgando un huacal a su tamaño. Esta forma de participación desde los brazos de su padre, es la manera socialmente indicada de manifestar que el hijo a medida que continúe creciendo, seguirá participando en la entrega de este don que está dirigido a los dioses. Ver fotografía 25.

El contexto de esta danza regional, consiste en dos filas de serranos que se extienden a lo largo de la Calle de la Cruz. En medio de ambas filas, aparecen un grupo exclusivo de señoritas precasaderas (niñas) y varones disfrazados de mujer (usando falda y blusa de manta bordada), quienes traen una canasta con algún fruto de la temporada. Por no haber un nombre específico para estos varones disfrazados, les llamaré: serranas.

La comparsa está acompañada de una banda clásica que toca un son especial para esta representación. El desarrollo de la danza consiste en que los serranos caminan de un extremo al otro del escenario con el ritmo pausado que va marcando la música; cada paso que dan los participantes, va acompañado de un golpe del palo contra el suelo.

Esporádicamente los serranos, giran sobre su eje noventa grados en cuatro ocasiones consecutivas, marcando cada cuarto de vuelta con un bastonazo en el suelo, las señoritas precasaderas y los varones disfrazados del centro de la comparsa, levantan en lo alto sus respectivas canastas en cada cuarto de vuelta que también realizan. Cabe argumentar que cada cuarto de vuelta representa un punto cardinal, y a manera que se indican los cuatro puntos cardinales de manera inmediata, aluden simbólicamente por metonimia a la rosa de los vientos. Así mismo, el ejercicio metonímico se justifica sobre la base de los listones de colores que están colocados en el bastón, y que en este contexto simbolizan las fuertes corrientes de viento que se encuentran en la sierra, y que hace girar la rosa de los vientos.

De la misma forma, el bastonazo que realizan los serranos contra el suelo, indican las direcciones y futuros caminos por los cuales se puede surcar la serranía (de Tepetlaoxtoc en este caso). Por su parte las señoritas precasaderas y los varones disfrazados (serranas), al levantar sus canastas en dirección de los cuatro puntos cardinales solamente tratan de indicar el origen de los frutos que poseen. La acción también puede ser interpretada como una forma de saludo-agradecimiento a los dioses que permiten la recolección de esos frutos que están dispersos en esas cuatro direcciones. $Y$ en el caso exclusivo de las niñas, refiere a su facultad innata de la reproducción que dentro de pocos años podrán manifestar y ejercer. 
Fotografía 25.

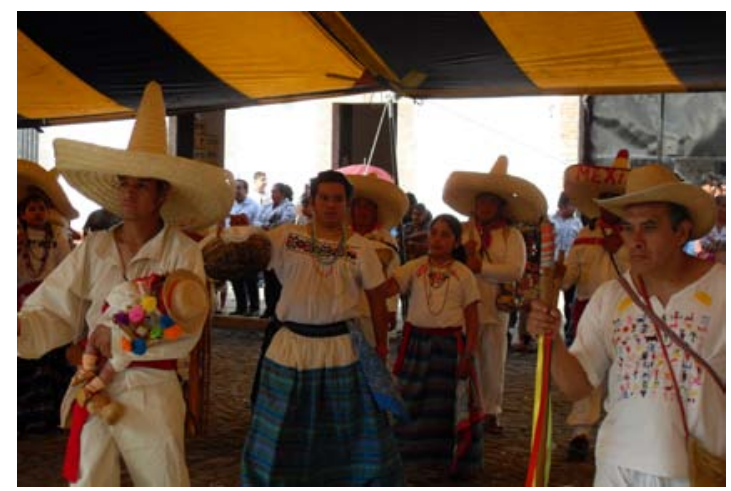

Al frente padre "serrano" cargando a su hijo, que también esta vestido para el baile. Notar que en segundo plano, se encuentra una serrana u hombre disfrazado de mujer que carga una canasta

\section{El simulacro de los arrieros (Los bandidos de Río Frío)}

"Con la actividad que le era genial, e impulsado por la monomanía del robo, no perdió tiempo; hizo venir a Evaristo de la montaña, conferenció largamente con él, diciéndole sus planes ...e invitándole a que, con la mayor parte de sus rurales, asistiese a la feria de Tepetlaoxtoc y reclutase allí a cuanta gente creyese necesaria para formar dos o tres cuadrillas, que podían servir alternativamente de soldados o caballeros errantes" (Payno; 2004: 713).

A las tres de la tarde se escucharon una serie de cohetes y balas, inmediatamente aparecieron la mayordomía de los arrieros en la calle Jardín, siguieron por Tlacaluca, Ocoyococ para finalmente llegar a la Plaza San Sebastián y su capilla. En estos momentos la comparsa de los serranos finalizó con su tributo, para ya no volver a presentarse. Se realizó la eucaristía con las mismas características de las demás, y como es costumbre la mayordomía se retiró para merecer sus alimentos. A las cinco de la tarde comenzó el simulacro de los arrieros (bandidos de Río Frío), que consistió en lo siguiente:

En la parte superior de la Calle de la Cruz, específicamente en donde está el árbol seguido de la cruz de piedra, se conglomeraron algunos arrieros que en su mayoría estaban vestidos con trajes de manta blanca ("gente del pueblo"). A su vez, en la esquina de la calle Tlacaluca con Jardín se amontonaron otro grupo de arrieros, pero que estaban vestidos de vaqueros y algunos con traje de manta; es decir, no había un uniforme específico a comparación del primer grupo. Este nuevo grupo representaría a los bandidos, y para otorgarle un mayor realce a la escena, algunos de sus miembros se colocaron paliacates en la mitad del rostro. Ver fotografía 26. 
Fotografía 26.

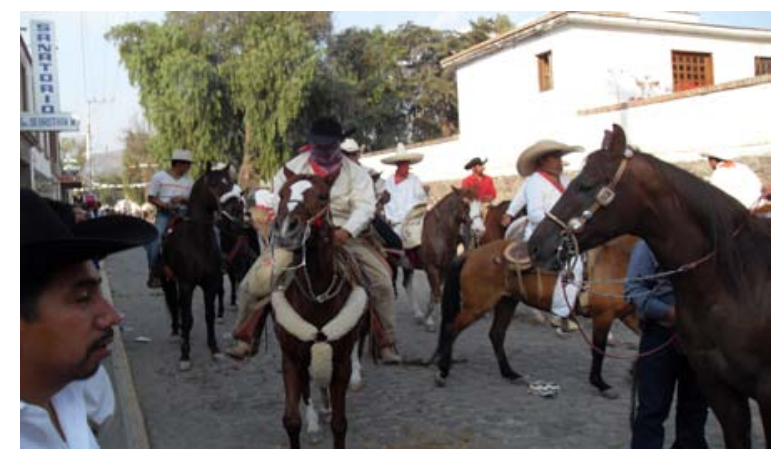

Bandidos huyendo con dirección a "la sierra".

El simulacro comenzó con una serie de descargas al aire que efectuaron todos los bandidos, después arrancaron sus caballos y a galope cruzaron en cuestión de segundos más de 15 jinetes toda la calle de Tlaxcantla hasta llegar a donde estaba el otro contingente. Se continuaron escuchando disparos, pero ahora, desde donde comienza la Calle de la Cruz. Seguidamente se regresaron a galope los bandidos hasta llegar nuevamente a la esquina de Tlacaluca-Jardín, pero acompañados de una mula que cargaba dos sacos llenos y algunas tlacualeras que habían sido secuestradas. El hurto de la mercancía, pero sobre todo el robo de las mujeres (tlacualeras), obligó a los miembros del pueblo (o miembros de la misma banda) a detonar unos cartuchos y perseguir a galope a los otros bandidos que recientemente habían huido.

\section{Fotografía 27 y 28}

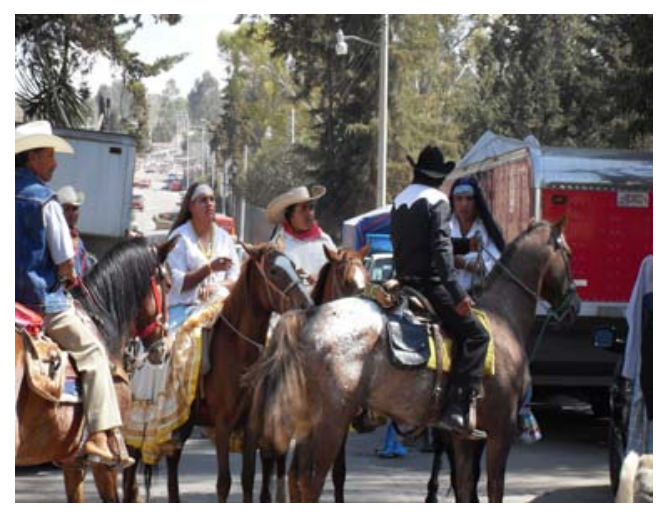

Las Tlacualeras.

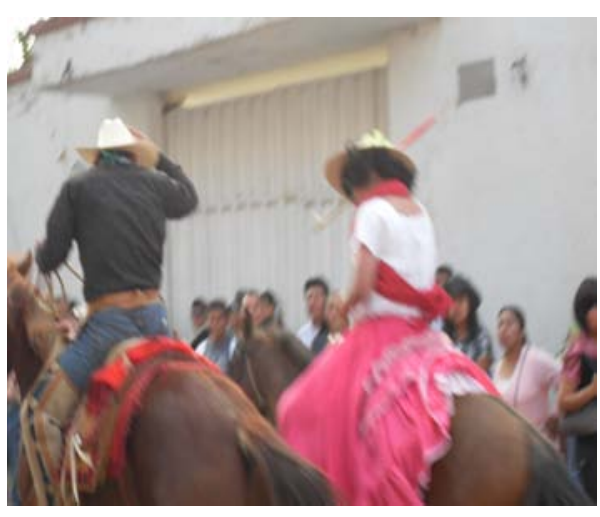

Bandido huyendo con una tlacualera.

Con ayuda de una cuerda para lazar, varios arrieros atrapaban a uno o dos de los bandidos y los regresaban a la Calle de la Cruz. También se recobraba la mula con la carga, pero no a las tlacualeras. En la Calle de la Cruz, se les bajaba con "violencia" a los bandidos de sus caballos, 
se les amarraba de los tobillos y se les colgaba del árbol. Inmediatamente después se escuchaban las órdenes de:

$$
\text { ¡Preparen!... ¡Apunten!... ¡Fuego! }
$$

Y resonaban varias detonaciones en dirección al colgado 0 al cielo, estos fueron de los pocos cartuchos de salva que se utilizaron en todo este día.

La representación continuaría de esa manera hasta que se acabarán todos los bandidos y se terminará por fusilar a las tlacualeras. Un comentario al respecto, puede ser:

"A las tlacualeras también las fusilan, ¡Por perras!.

Hace tres años, yo también participaba como tlacualera. Ahí esta el desmadre"

(Comentario de César Almeraya, oriundo del barrio de la Candelaria, Jolalpan, Tepetlaoxtoc).

Otro de los detalles que caracterizó a esta mayordomía, fue que: principalmente los bandidos regalaban vasos con tequila a quién lo solicitará, de la misma forma los arrieros, obsequiaban pinole con sólo extender la mano.

Interpretación.

Para los deseosos de conocer un posible incidente trágico de esta representación, sugiero revisar el Anexo 5.

Como se ha podido observar con anterioridad, algunas de las calles del centro de Tepetlaoxtoc se fueron transformando simbólicamente al trascurrir los días de las diferentes mayordomías satelitales en honor a San Sebastián Mártir.

El caso recuerda la Calle de la Cruz, que en una primera ocasión se convirtió en una hacienda ganadera con ruedo según la danza de los vaqueros, después se transfiguró en un campo agrícola o de siembra con la danza de los y las sembradoras. Con el trascurso de los días y en particular en la mayordomía de los tlachiqueros varias de las calles que están a las orillas del centro se relacionaron con los diversos cerros en los que había mageyales para raspar. En ese día, la Calle de la Cruz se transmutó simbólicamente en una extensión del recuerdo de la primera pulquería autorizada en Tepetlaoxtoc; es decir, la "Pulquería Xóchitl".

En lo que respecta a la mayordomía de los albañiles, la Calle de la Cruz se volvió un espacio para la construcción. Que días después, se deformaría simbólicamente en algún paraje de la serranía propia de este municipio, con la danza de los serranos.

Una respuesta a las constantes transformaciones simbólicas que sufre el espacio, se puede encontrar con George Balandier, cuando afirma: 
"Las ciudades fundadas en el seno de la larga duración históricas están compuestas por múltiples escenarios, levantados por sucesivos regímenes. Despliegan un espacio urbano en el que abundan símbolos y significaciones" (Balandier; 1994: 25).

"...las fiestas ponen en escena las jerarquías constitutivas de la sociedad con el fin de exponerlas, de confirmarlas o contestarlas simbólicamente en unas pantomimas sagradas que son celebraciones como la del Asno o las de Locos. Se escenifican los requisitos, las pasiones, las emociones: en los toneos, en los juegos de sociedad y en los juegos de amor." (Balandier; 1994: 37).

Porque, la relación que existe entre los simulacros (tlachiqueros y albañiles) o las danzas regionales (vaqueros, serranos, sembradores y sembradoras) que se realizan con motivo del ciclo festivo del mes de enero deben ser entendidas como representaciones directas de las actividades económicas que se desarrollaron históricamente desde el periodo postcolonial en este municipio y que en la actualidad, aunque ya no sean oficios rentables en la mayoría de los casos, perduran en el recuerdo de sus habitantes. Éstos, se insertan de generación en generación en las distintas danzas o los simulacros, de manera muy análoga a la doble metamorfosis de Godelier. Con la diferencia que en Tepetlaoxtoc, se transmiten dones que son dirigidos a los dioses.

Siguiendo el referente del ensayo de Balandier, se puede citar:

"Toda ciudad se va enriqueciendo, a lo largo de su historia, de estos lugares a los que puede serles atribuidos una función simbólica, que reciben de manos del destino o que obtienen de los acontecimientos. Se trata de teatros en los que la sociedad $<<$ oficial $>>$ se produce, y en los que, al contrario, la propuesta popular se <<manifiesta $>>$. La topografía simbólica de una gran ciudad es una topografía social y política" (Balandier; 1994: 26$)^{59}$.

Un equivalente a los <<teatros >> que refiere Balandier en el territorio de Tepetlaoxtoc, pueden ser los edificios (hechos duros), parajes y cuevas que comenta la historia oral fueron frecuentados o utilizados por los bandidos de Río Frío, tal es el caso de una casa de seguridad y la pulquería del Portón, mencionando solo algunas. En ese sentido, el hecho de presentar dos bandos contrarios, es decir: "uno bueno, el otro malo", "miembros de la ley y el orden, los otros representan el caos y la anarquía", "unos defienden las causas del pueblo (gente honesta), los otros buscan satisfacer sus intereses personales dañando al pueblo (robando a los honestos)", "unos trabajan, los otros roban", "unos son gente del pueblo, los otros son bandidos del pueblo". Son algunas de las dicotomías que se encarnan y teatralizan, en los personajes que se encuentran en cada extremo de la calle de Tlaxcantla durante este festejo en tributo a San Sebastián. Por ende, sea o no cierta la novela de "Los bandidos de Río Frío", o mejor dicho,

\footnotetext{
${ }^{59}$ Subrayado mío.
} 
Manuel Payno se haya o no inspirado en hechos reales de la época. Se puede suponer que en algún momento de la historia Tepetlaoxtoc la población vivió asolada por alguna banda de malhechores que utilizaron al pueblo como una madriguera. Lo anterior infiere con la identificación que tienen los vecinos del municipio con esta novela, los hechos duros fácilmente reconocibles, la historia oral y las redes de parentesco que remiten a los orígenes obscuros de "caballeros errantes".

El contexto anteriormente descrito, remite a un rito histórico de paso -en términos de DaMatta-, retomo:

“...el tiempo del Día de la Patria es único, acentúa el rompimiento definitivo con el periodo colonial y el inicio de una "mayoría de edad política" ...ya que su performance busca no sólo recrear un momento glorioso del pasado, sino muy especialmente marcar el paso entre el mundo colonial y el mundo de la libertad y autodeterminación. De esta manera, los acontecimientos históricos y empíricamente registrados se consideran paradigmáticos, y los personajes que los engendran se consideran héroes nacionales de carácter oficial" (DaMatta; 2002: 64)

Tras esa vía, puede ser que la banda tuviera otro nombre distinto a "Los Dorados", pero lo que sí es verdad, es que parte de la gente del pueblo necesitó organizarse y combatir hasta el último de los asaltantes que estaban en Tepetlaoxtoc, como una forma de recobrar el orden social que generaciones atrás se había perdido. Pues el performance que se desarrolla en el simulacro de los arrieros, solamente busca revitalizar en las mentes de los habitantes de Tepetlaoxtoc, un hecho histórico "glorioso" que consistió en perseguir, atrapar, colgar y fusilar a todos los bandidos que alguna vez habían robado la tranquilidad y seguridad a su comunidad. Ya que con la muerte de los malhechores, se recobró por siempre la paz que gozan las personas honestas. Esta tranquilidad propia de los pueblos continúa hasta la actualidad -según me lo hicieron ver los comentarios de varias personas en distintas comunidades. Pero quedan dos preguntas al aire: ¿Por qué razón no se rescata a las tlacualeras de las manos de los bandidos? Y ¿Por qué se fusilan a todas las tlacualeras, si ellas fueron las víctimas del robo? Se tiene que tomar en cuenta, que las tlacualeras -en este contexto- simbolizan a las mujeres que fueron secuestradas o literalmente arrancadas de sus hogares por los bandidos en alguno de los sitios que fueron asaltados. Éstas, fueron llevadas a alguna casa o zona de seguridad y tratadas como objetos sexuales suponiendo que hubo violaciones y ultrajes colectivos. Al respecto Héritier proporciona una cita que viene acorde al suceso:

"En primer lugar, se trata de marcar un territorio material o animal; como ese cuerpoterritorio pertenece a otros hombres, el ataque que se le hace -que va más allá de la corporeidad y del placer físico de la posesión- pretende afectar el honor de los hombres. 
En segundo lugar, de manera exacerbada en ciertas culturas, el honor masculino reside en la virtud de las mujeres de la familia" (Héritier; 2007: 77) ${ }^{60 .}$

Entonces es entendible que el robo-violación provoca la deshonra masculina de los familiares consanguíneos y progenitor de la victima. Y sí se toma en consideración que la sangre-semen es una vía de transmisión de las cualidades de los varones, como lo explicó Héritier -cito-:

"El semen masculino contiene en potencia las cualidades de los individuos que nacerán de las relaciones sexuales mantenidas con suficiente asiduidad; cualidades entendidas incluso, según su definición más inmaterial, como creencias religiosas o convicciones políticas" (Héritier; 2007: 78).

Por lo tanto, los hijos que nacerán como resultado de la violación que ejercen los bandidos, serán productos que denigran a todos los varones honorables parentalmente cercanos a la víctima, pero ¿Ese es el motivo para ahorcar y fusilar a las tlacualeras? 0 ¿Existe algún otro castigo que no implique la muerte de estas dos personas ${ }^{61}$ (tlacualera y descendencia), como el destierro? La respuesta es No, socialmente no se puede otorgar ningún otra pena más que la muerte, pues el delito no fue su desgracia de ser "mujeres marcadas" tras el infortunio de haber sido robadas y violadas o ultrajadas por los bandidos. Sino que se está juzgando el comportamiento socialmente impropio que mostraron las tlacualeras durante las mayordomías satelitales de los gañanes, tlachiqueros, comerciantes, albañiles y por su puesto arrieros. Es decir, el hecho de beber, dejarse manosear, sacar a bailar a cuanto hombre se encontrarán en su camino o arrojarse a los brazos de cualquier hombre para que "se abrazarán", son sólo algunos de los delitos por los cuales se justifica socialmente la pena de muerte. Ya que en el lenguaje de los pueblos mesoamericanos, el término "abrazar" entre personas de diferente género, alude a tener relaciones sexuales previas a una alianza matrimonial. Por ende, las tlacualeras caen por analogía en la categoría de putas que propone DaMatta, retomo:

"...la mujer como puta. La mujer que los hombres no controlan. Al contrario, ella es la que controla y es el centro de una red de hombres de todos los tipos, pues ¿quién es la puta sino aquella que pone a todos los hombres en relación? ...volviéndose, por otro lado, un centro de poder comparativo y controlador de la sexualidad masculina" (DaMatta; 2002: 151)62

Por lo tanto, siguiendo el rito histórico de paso que tuvo que pasar la comunidad de Tepetlaoxtoc para volver a recobrar el orden que se mantenía antes de la llegada de los caballeros errantes,

\footnotetext{
${ }^{60}$ Subrayado mío.

${ }^{61}$ Empleo este término de DaMatta, pues el anonimato no es propio de los pueblos mesoamericanos contemporáneos, y mucho menos desde un siglo atrás. Tomando en cuenta la poca población que los conformaban.

${ }^{62}$ Subrayado mío.
} 
fue necesario matar a las mujeres que los apoyaron y que cuestionan el dominio masculino. Porque:

Esta situación "Muestra a qué quedaría sometida una sociedad si se disolvieran las normas, las prohibiciones y los códigos: a una regresión a ese salvajismo que él mima en ciertos de sus excesos, a un quedar a merced de monstruos parecidos a aquellos con los que el imaginario tibetano poblaba la escena humana. Tienen a su cargo el desorden, las turbulencias individuales y colectivas ...Al bufón se le otorga el lado de lo peligroso, pero a condición de ser él quien lo desencadene" (Balandier; 1994: 58)

Y para evitar una regresión a ese salvajismo, se requiere la muerte de la descendencia y todos los hijos que podrían nacer que son resultado de la unión entre los bandidos y las tlacualeras, pues al crecer serían los futuros bandoleros de la región. Y como este rito histórico de paso, forma parte de la identidad de todos los tepetlaoxtoqueños (hombres y mujeres), sin olvidar que el ritual permite ordenar el cosmos y el dominio masculino en la región; el simulacro será realizado a finales del mes de enero del próximo año, como es costumbre. 


\subsection{Espacios para lo femenino.}

Comento que este apartado del ensayo contendrá dos subtemas que serán desarrollados como una parte integral de los espacios de lo femenino.

\section{-Violencia contra la mujer-}

Flores Martos (2005) y Vendrell Ferré (2005), comentan sobre la intensidad que ha alcanzado la violencia contra las mujeres, por ejemplo: hablan de agresión y violencia contra el género femenino, que incluye: violación, agresión, violencia conyugal, hostigamiento sexual y su recriminación por parte de las autoridades, pero no se hace referencia a la violencia simbólica que también afecta al género femenino.

Durante el corto tiempo de investigación, no se pudo encontrar ni un sólo caso de violencia contra el género femenino, lo que no significa que no existan en el municipio. En una futura investigación se pretenderá tocar este tema, pero por el momento, me limito a presentar algunos casos de violencia simbólica contra la mujer que se desarrollaron en las diversas mayordomías, y por su puesto sus niveles de resistencia.

Para comenzar, cito de Thompson (2003) la definición de violencia simbólica:

"La violencia simbólica no es ninguna forma de dominación ejercitada a través de la comunicación: es el ejercicio de la dominación a través de la comunicación de tal forma que la dominación es desconocida como tal y por lo tanto reconocida como legítima" (Thompson; 2003: 68) Y continua: "...el concepto de violencia simbólica presupone una forma de complicidad, una forma de reconocimiento sin reconocimiento, a través del cual y mediante la dominación es sostenida" (Thompson; 2003: 69)63.

Y si a la cita anterior, se le incorpora la noción de la valencia diferencial de los sexos. Que puede ser nuevamente retomada de Héritier:

"La valencia diferencial de los sexos es un fenómeno tan masivo que se vuelve invisible, como un dato natural no cuestionable, a pesar de que no es natural y puede ser cuestionado. Así, el privilegio confiscado se convierte en desventaja. Para que la confiscación sea irreversible, las mujeres fueron confinadas en todas partes a un rol de procreadoras domésticas, excluidas del uso de la razón, excluidas de lo político, excluidas de lo simbólico. En este último punto es donde se juega la fuerza física del hombre" (Héritier; 2007: 178) ${ }^{64}$.

Tomando en cuenta ambas posturas (Thompson-Héritier) que tienden a ser complementarias entre sí, se puede volver a revisar el caso de la mayordomía satelital de las molenderas, por ser el único espacio en donde participaron exclusivamente las mujeres (contadas niñas, señoritas casaderas, madres, esposas y abuelas), relegando temporalmente a los hombres a realizar

\footnotetext{
63 Subrayado mío.

${ }^{64}$ Subrayado mío.
} 
labores que no requerían ninguna demostración viril. Así mismo, las calles fueron tomadas por el género femenino y por distintos tipos de familias (nucleares, monoparentales y algunas reconstruidas) que representaban el ámbito doméstico, y que expulsaron o inhibieron la cantidad de varones que se dedicaron a embriagarse durante esta festividad en particular.

Bajo este panorama, me atrevo a comenzar acercar la mayordomía de las molenderas con los rituales de rebelión de Gluckman, pero vistos desde los ojos de Rodrigo Díaz (1998). Es decir retomo-:

"Gluckman descubrió que existe cierta clase de ritual que no sólo expresa abiertamente las tensiones sociales, tiende además a exagerarlas, a representar, magnificándolos, los conflictos fundamentales de la sociedad. Estos rituales, llamados de rebelión, reinstauran la unidad del grupo a pesar de que los conflictos sociales que les sirven de referencia y que ellos se encargan ampliamente de dramatizar" (Díaz Cruz; 1998: 171) Y sigue más adelante: "Que las mujeres <<suspendan〉> por un momento las restricciones habituales (la normatividad legítima) a que están sujetas, y desplieguen un comportamiento invertido, ¿es suficiente para nombrarlo ritual de rebelión? No, diría Gluckman, es necesario además que exprese, magnificadas, las tensiones y conflictos sociales, y de esa expresión el sistema saldrá renovado y revitalizado en su unidad, pero una unidad sacralizada por la tradición ...También representa las tensiones sociales y psicológicas a que están sujetas las mujeres ...representan $<<$ la incompatibilidad e inconsistencia entre la obligación de la esposa de ser fértil y de reforzar el grupo del marido por un lado, y la escisión que de hecho se deriva su fertilidad >> (Gluckman, 1978: 265)" (Díaz Cruz; 1998: 173).

La misma cita de los rituales de rebelión marca su distancia con la evidencia observada, porque sí es verdad, que muchos de los varones no participaron en esta celebración por considerarla $\ll$ cosas de mujeres $\gg$, también es cierto que las mayordomas invitaron a comer a sus amigas, parientes consanguíneos y rituales, pero exclusivamente femeninos. Así mismo en el solar donde se ofreció la comida, varias mujeres se tomaron una o dos copas de alcohol y fumaron varios cigarros; situación que no fue evidente en los otros festejos o sin la presencia de sus maridos y / o padres. Y sí se podría argumentar, que en las calles no se observó ninguna mujer ingiriendo bebidas embriagantes, pero también se debe decir, que ellas se apropiaron de todos los espacios públicos hasta altas horas de la noche y que su presencia limitó el número de borrachos y el número de cantinas temporales que ofrecieron sus servicios por este día -como ya se había comentado. En resumen: la mayordomía de las molenderas solamente debe ser vista como una suerte de ritual de rebelión que les permite a las mujeres gozar con medida de ciertos placeres que son exclusivos de los varones, sin la necesidad de que estén ellos presentes.

Sin embargo, al día siguiente la violencia simbólica no se hace esperar con la primera aparición de las tlacualeras desde la mayordomía satelital de los gañanes hasta los arrieros. Donde esta 
brusca aparición de hombres disfrazados de mujeres, que son sexualmente accesibles hasta el grado de asociarse con las putas -en términos de DaMatta-, son solamente un ejemplo de la capacidad de simbolización que ejercen los varones en represalia al empoderamiento que hicieron las mujeres del espacio público durante la celebración del día anterior. Sobre el mismo ámbito (la capacidad de simbolización), varios hombres se apropiaron de algunos papeles femeninos durante tres de las cuatro danzas que se realizaron como don a los dioses (en particular a San Sebastián Mártir), me refiero a los personajes de: María Cristina (en la danza de los sembradores y las sembradoras -Ver fotografía 29) y las serranas (en la danza de los serranos -recordar fotografía 25).

Fotografía 29.

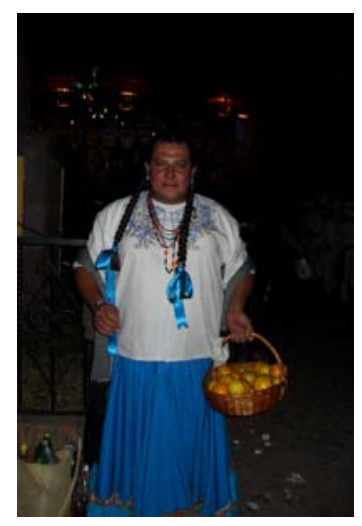

María Cristina

(Esposa del patrón y que es acosada sexualmente por el Hue-hue).

Cabe sugerir que las niñas serranas (señoritas precasaderas) de la danza de los serranos, su actividad en el baile se limita simbólicamente a dar las gracias a los dioses por los frutos que recogerán en los futuros años a partir de su pubertad. En otras palabras, se agradece por la descendencia que procrearan y que finalmente sea apropiada por los varones. En ese sentido, no se puede olvidar el caso de las chinas poblanas que participan en la danza de los vaqueros, quienes son personas que reflejan del capital social, económico y simbólico (por la belleza natural de la señorita) que poseen los varones con los que está emparentada (padre y hermanos). Porque:

“...el honor masculino reside en la virtud de las mujeres de la familia" (Héritier; 2007:77).

El contexto anteriormente expuesto requiere que realice una breve acotación: 
Durante las cuatro danzas anteriormente descritas e interpretadas (las sembradoras, los sembradores, vaqueros y serranos), si hubo la participación de mujeres en todas y cada una de ellas, unas en más medida que las otras, pero al final participaron. El detalle se encuentra en que las mujeres tuvieron que vestirse con prendas semejantes a la de los varones, de esa manera se les arrancó su feminidad al no poder mostrar algún elemento que remitiera a su identidad genérica, es decir: pelo largo suelto, el uso de falda, la debilidad física, etc. En ese sentido, las únicas mujeres que se presentaron son: las serranas y chinas, ya que al contrario de ocultar sus elementos de identificación genérica los resaltaron. Al respecto, en la danza de las sembradoras y los sembradores, algunos de los papeles principales fueron desarrollados por mujeres muy masculinizadas.

\section{-Resistencia femenina-}

Para comenzar con este apartado le recuerdo al lector la cita que está a principios del ensayo sobre la resistencia:

"En circunstancias normales, los subordinados tienen interés de evitar cualquier manifestación explicita de insubordinación ...minimizar las exacciones, el trabajo y las humillaciones que reciben. La reconciliación de estos dos objetivos, que parecen ir en sentido contrario, se logra en general insistiendo en aquellas formas ...que evitan una confrontación abierta con las estructuras de autoridad ...Sólo cuando fracasan las medidas menos drásticas, cuando la subsistencia se encuentra amenazada o cuando hay signos de que puede atacar con relativa seguridad, el campesinado se atreve a seguir el camino del desafío abierto y colectivo. Por esa razón, el discurso oficial entre el dominante y el subordinado está lleno de formulas de servilismo, de eufemismos y de indiscutidas pretensiones de estatus y de legitimidad" (Scott; 1990:113).

Durante la investigación logré encontrar algunas formas de resistencia femenina frente al dominio masculino, las cuales menciono a continuación:

1) No realizar comida para el día de la fiesta del pueblo.

2) Dejar a los hijos (infantes) a cargo de su progenitor durante la fiesta grande o una mayordomía satelital.

3) Como una posibilidad: El uso del anonimato por parte de las señoritas oriundas en espacios públicos fuera del municipio.

\section{Primer punto.}

A medida que se va acercando el día de la fiesta patronal del barrio (en el caso de Jolalpan o Tepetlaoxtoc centro) 0 en alguno de los pueblos del municipio, las madres-esposas, hijas (solteras) y nueras (que residan de manera patrivirilocal), se organizan según la tutela de la 
suegra-madre para comprar los ingredientes y preparar el mole propio de las festividades patronales mesoamericanas. Esto se hace sin olvidar, que serán ellas, algunos familiares femeninos y amigas de confianza, quienes se dediquen a servir los platos y atender las mesas de los invitados durante la reunión.

Los varones por su parte se dedican a conseguir las bebidas embriagantes y hacer extensiva las invitaciones a sus familiares, compadres sacramentales y no sacramentales, amigos, compañeros del trabajo, vecinos, etc. Debo señalar que en Tepetlaoxtoc, solamente son los hombres los únicos socialmente autorizados para realizar las invitaciones a otros varones sin importar su condición social. Cabe mencionar, que presencié contados casos en que la esposa tomaba la iniciativa e invitaba a los varones pero en todos los casos se encontraba presente su marido, quién ya estaba enterado de la propuesta u otorgaba o no su visto bueno.

Se espera que los invitados comiencen a llegar a entre las 2:00 p. m. Y 4:00 p. m, acompañados de sus familias nucleares o solamente de su esposa; dependiendo de la confianza que exista con el anfitrión, se podrá a su vez invitar o no a más personas.

Como un acto de rebeldía abierta y enfrentamiento directo frente a la autoridad masculina, en ocasiones la esposa-madre-suegra decide no hacer ningún tipo de alimento para la fiesta patronal. Los gritos, malos tratos, ocasiones que el marido se ha embriagado, golpes y quizá violaciones son la justificación, por lo tanto, sí el marido pretende hacer una reunión en su casa, tendrá que contratar un servicio de banquete o pagar alguna señora para que realice la comida, que con motivo de la festividad los precios de estos servicios ocasionales tienden a subir.

En las ocasiones que logré presenciar este acto de resistencia femenina, el día festivo concluía sin haberse realizado alguna reunión en el solar de estos varones.

\section{Segundo punto.}

Como se ha comentado anteriormente el consumo de bebidas embriagantes es común al interior del municipio principalmente en: una reunión social, la fiesta patronal (del barrio o pueblo), un rito de paso eclesiástico o por "el simple gusto de haberse encontrado". La celebración o la circunstancia, obliga a los distintos varones a reafirmar su amistad con el consumo excesivo de alcohol; recordaremos que una vez que un varón acepta brindar con otro u otros, tendrá la obligación de beber las mismas cantidades y a la misma velocidad ("al parejo") que sus acompañantes. Por ende, una botella de un litro se puede acabar en tres o cuatro rondas entre cuatro participantes. Situación que hace a estos brindis, un elemento sumamente masculinizado. Para ejercer una resistencia femenina, las esposas encargan a sus hijos o hijas infantes a los cuidados de su padre, como una medida que regulará la cantidad de alcohol que podrá consumir 
en ese momento y el tiempo que permanecerá ese varón separado de su esposa o familia. Esta forma de resistencia se hace evidente sí es que el marido acaba de encontrarse con sus familiares masculinos, compadres o amigos en un evento en la vía pública, como es el caso de los bailes, jaripeos, rodeos, palenques, la fiesta grande, simulacro de alguna mayordomía o una mayordomía satelital. El poder que ejerce esta forma de resistencia es tan notable, que su práctica la vi extendida durante todos los festejos del mes de enero, pero principalmente en la mayordomía del "20 de enero" o la fiesta grande.

\section{Tercer punto: "El uso del anonimato fuera del municipio".}

Tomando en consideración que en las sociedades pequeñas (barrios y pueblos mesoamericanos) que se caracterizan por ser jerarquizantes, tradicionales y donde muchos de sus habitantes comparten vínculos de parentesco por alianza, consanguinidad y ritual (sacramental o no); el anonimato no existe, sino, predomina la noción de persona. En cambio en las ciudades, existe la noción de individuo. Pues, individualizar significa que la persona se encuentra desvinculada de su casa, sus respectivas redes de parentesco y laborables, sus relaciones políticas y amistades, sus títulos académicos y demás medallones. En pocas palabras significa que el individuo es un "ente" socialmente desubicado y desconocido en espacios jerárquicos e intersticiales propios de algunas calles y vías públicas de las grandes urbes.

En ocasiones, la situación obliga al individuo a echar mano de la siguiente pregunta: “¿Sabe con quién está hablando?", frase que forma parte de un ritual autoritario contemporáneo que es exclusivo de las grandes ciudades, y que se utiliza, en el momento que el individuo percibe que se le ha trasgredido su integridad social y el status que lo caracteriza. DaMatta, lo explica de la siguiente manera:

"Pues esa fórmula sólo debe o puede operar funcionalmente en una sociedad de gente, de personas que se lavan, de blancos, de buena gente, de medallones, en oposición a la gentuza, al hombrecillo común, a la escoria, al populacho, a la masa; en una palabra a los impuros en general ... un sistema general de clasificación donde las personas están marcadas por categorías extensivas, de un modo binario. De un lado, los superiores; del otro, los inferiores" (DaMatta; 2002: 209).

"En otras palabras, el "¿Sabe con quién está hablando?" permite establecer a la persona donde antes sólo había un individuo."(DaMatta; 2002: 225)

En ese sentido el agredido social termina por ser el agresor, al echar mano de la jerarquía social que sus relaciones de parentesco, social y políticas, aunado a la muestra de sus (títulos 
académicos, reconocimientos sociales, etc.) ante un inferior que no comparte dichos vínculos y no posee tales credenciales.

Como anteriormente se comentó: Durante los festejos de la mayordomía de los tlachiqueros, varias señoritas haciendo uso de su calidad de individuos anónimos, se dieron el lujo de realizar bailes y comportamientos sexualmente provocadores, embriagarse 0 drogarse y en algunos casos hasta tener relaciones sexuales en la vía pública. Pero sí se voltea el ángulo de percepción, se podrá preguntar ¿De qué manera podrían utilizar el anonimato las señoritas oriundas de Tepetlaoxtoc? Tomando en cuenta que la oferta académica al interior del municipio se encuentra limitada a una preparatoria pública (en Tepetlaoxtoc centro) y otra privada (en el pueblo de Jolalpan), solamente provoca que los deseosos de estudiar una carrera profesional o continuar sus estudios en el nivel medio superior tengan la necesidad de continuar su educación en los municipios vecinos de Chiconcuac, Texcoco, Tizayuca, Chimalhuacan y Nezahualcóyotl 0 dirigirse hacia al Distrito Federal. Este traslado, les otorga a los jóvenes (varones y señoritas) la capacidad de ir abandonando paulatinamente su categoría de persona para ser sustituida por la de individuo en la medida que se van alejando de su municipio de origen y de las personas que los y las conocen.

En el caso de las señoritas tepetlaoxtoqueñas, existe la posibilidad de que a manera en que se van transformando de personas a individuos en las grandes ciudades, su comportamiento sexual también pueda cambiar el anonimato que ahora la preside y el uso de anticonceptivos, porque:

"Gracias a la anticoncepción, la mujer se convierte en la dueña de su cuerpo y ya no es considerada como un simple recurso; utiliza su libre albedrío en materia de fecundidad, incluida la elección del cónyuge, la elección del número de hijos que desea y el momento en que quiere tenerlos. Ella puede también poner fin a un sistema de dominación que consistía en utilizarla para concebir hijos" (Héritier; 2007:128)65. Sin olvidar, que solamente ella podrá regular la cantidad de parejas sexuales con las que desea mantener una relación.

Su situación de "anonimato", no afectará la imagen pública que tiene en Tepetlaoxtoc al no existir ninguna evidencia de sus transgresiones sexuales y resistencias frente a sus padres y hermanos, ya que "el honor masculino reside en la virtud de las mujeres de la familia". En ese sentido, solamente sus nuevas redes sociales que están fuera del municipio de Tepetlaoxtoc y que también la consideran como persona, sabrán qué tipo de persona es; es decir, puede ser una joven que gusta del placer de la sexualidad controlada y anónima hasta el grado de ser considerada como una puta -en términos de DaMatta. Imagen, que no afectará a la figura que

\footnotetext{
${ }^{65}$ Subrayado mío.
} 
mantiene en su hogar o en su comunidad mientras no exista alguna evidencia de esas transgresiones sexuales, como puede ser: uno o varios testigos que la ubiquen al interior del municipio, un embarazo no deseado o alguna situación embarazosa al interior de la comunidad.

\subsection{Una aproximación al ethos de los tepetlaoxtoqueños.}

¿Qué se entiende por ethos?, la definición la propone Geertz:

"El ethos de un pueblo es el tono, el carácter y la calidad de su vida, su estilo moral y estético, la disposición de su ánimo; se trata de la actitud subyacente que un pueblo tiene ante sí mismo y ante el mundo que la vida refleja. Su cosmovisión es su retrato de la manera en que las cosas son en su pura efectividad; es su concepción de la naturaleza, de la persona, de la sociedad. La cosmovisión contiene las ideas más generales de orden de ese pueblo. Los ritos y las creencias religiosas se enfrentan y se confirman recíprocamente; el ethos se hace intelectualmente razonable al mostrarse que representa un estilo de vida implícito por el estado de las cosas que la cosmovisión describe, y la cosmovisión se hace emocionalmente aceptable al ser presentada como una imagen del estado real de las cosas del cual aquel estilo de vida es una auténtica expresión" (Geertz; 1987: 118)66.

Al respecto se puede cuestionar: ¿De qué manera se puede definir al vaquero mexicano?, ¿Cómo se podría definir el vaquero tepetlaoxtoqueño? Y ¿Qué relación mantiene la imagen de San Sebastián Mártir con la identidad de los habitantes de Tepetlaoxtoc? La imagen del cowboy norteamericano comenzó a difundirse en los estados del norte de la república gracias a la cercanía geográfica y a las industrias culturales que comenzaban a explotar esta representación de la masculinidad americana. En cambio, para el resto de la república, se continuaba manteniendo la imagen del charro jaliciense como representante de la virilidad nacional; las características de este personaje fueron exaltadas en las películas de la "Época de oro del cine mexicano", mostrándolo como un varón apasionado a las apuestas en carreras de caballos 0 peleas de gallos y otros juegos de azar; es valiente, bebedor, broncudo (peleonero), cantor, pero sobre todo mujeriego. Con el tiempo ambas figuras de la masculinidad se fusionan para dar lugar al vaquero mexicano, que se caracteriza por ser un varón que se viste a la usanza norteamericana del cowboy, pero también gusta de poseer y disparar su arma de fuego, la doma de caballos y bueyes en el ruedo, la lidia de toros durante la faena, realizar peleas de gallos, beber grandes cantidades de alcohol (por lo regular tequila) y en ocasiones hasta rescatar el modelo tradicional de machista y mujeriego. En pocas palabras, subsiste la imagen del charro mexicano, pero vestido con ropa vaquera; que es propia de algunas industrias culturales, como: Wrangler, Resistol, Tardan, Levi's, Cacique, Cuernos chuecos, Espuela de oro, etc. Además de

\footnotetext{
${ }^{66}$ Subrayado mío.
} 
presentarse en eventos nacionales e internacionales, como son: "La Internacional Feria del Caballo", "Rodeo Cuernos Chuecos", "El Derbi de Jalisco", por solo mencionar algunas.

¿Qué podría identificar al vaquero tepetlaoxtoqueño, que a su vez, lo diferencie del modelo tradicional del vaquero mexicano propio de algunas regiones del país? La imagen del vaquero mexicano se extiende por casi todo el territorio del Acolhuacán Septentrional, como se puede corroborar en algunas comunidades de los municipios de San Andrés Chiautla, Papalotla, Tepetlaoxtoc, Texcoco y Tezoyuca. Donde varios de los varones recurren a esta vestimenta generalmente en los festejos de algún santo patrón, su participación en alguna danza regional (principalmente el baile de los sembradores y vaqueros), en algún jaripeo, palenque, faena taurina o baile que se puede efectuar sin la necesidad de una festividad o santoral.

En la actualidad es difícil identificar los motivos que asocian a esta representación masculina con este territorio (Acolhuacán Septentrional), pero una razón pudo haber sido la proliferación de ranchos, fincas y haciendas que surgieron desde el periodo postcolonial hasta finales de la revolución mexicana. De igual manera en algunos pueblos del Acolhuacán Septentrional la figura del vaquero mexicano ha servido como un elemento generador de capital simbólico que se complementa con la adquisición de prendas de marcas vaqueras reconocidas 0 de pieles exóticas, caballos, gallos de pelea, camionetas de doble tracción y su participación en los juegos propios de su masculinidad.

A diferencia de sus homólogos -que solamente fueron asediados-, el municipio de Tepetlaoxtoc fue el refugio de una serie de bandoleros que en la actualidad están asociados con "Los bandidos de Río Frío". La imagen de los "caballeros errantes de Tepetlaoxtoc" se encuentra presente en la memoria de los varios de los oriundos y avecindados inmortalizados en el rito histórico de paso de la mayordomía de los arrieros, donde se recrea la forma en que asaltaban, huían, eran aprehendidos y fueron ejecutados la mayoría de sus miembros. Otra forma de recordarlos, es con una supuesta descendencia directa de un antepasado que se dedicó a ser traficante 0 asaltante, cuyos frutos simbólicos y quizá económicos se vienen a cosechar hasta hace unas generaciones. En ese sentido, el vaquero tepetlaoxtoqueño se caracteriza por rescatar algunas de las cualidades de la figura del vaquero mexicano, pero a su vez, incorpora ciertos rasgos de sus predecesores. Donde el bandido moderno:

"Es un triunfador que sabe manejar la violencia. Es un aventurero que juega con el azar y comparte su fortuna con los amigos y los viejos conocidos de su pueblo ...su juventud se le va en la diversión y el derroche, en el disfrute de una existencia holgada que no desdeña lujos, y en la parranda con corridos y tambora que le permite sobrellevar las tensiones" (Campbell; 2004: 375) Y sigue: “...el representante de la raza, de este sector del pueblo cuyas aspiraciones son vivir al día, divertirse, burlarse de la justicia, andar en el cotorreo y en parrandas con tambora de tres días" (Campbell; 2004: 378). 
Por ende, la imagen del arriero tepetlaoxtoqueño que traficaba con pulque o madera ${ }^{67}$, asaltante de diligencias que iban hacía el Distrito Federal o el puerto de Veracruz y el retador de la ley, continúa siendo una actividad rentable en la actualidad, solamente que hoy el tráfico va desde pacas de prendas y falluca en general que se revende en el municipio de Chiconcuac y Texcoco o en los estados del norte de la república (Sonora, Chihuahua, Nuevo León y Tamaulipas), pasando por caballos y gallos que se consiguen o venden en diversas partes de la república o en la Unión Americana, la venta de automóviles americanos que fueron ganados en los palenques ${ }^{68}$ o carreras de caballos, quizá robados o comprados, hasta el tráfico de diversos tipos de armas de fuego que en su mayoría se utilizan durante los festejos que recuerdan su propio pasado, su propia historia de caballeros errantes, que hace de su vida una autentica expresión contemporánea.

Rescato la última pregunta: ¿Qué relación mantiene la imagen de San Sebastián Mártir con la identidad de los habitantes de Tepetlaoxtoc? Como anteriormente ya se hizo referencia, el arribo de la imagen de San Sebastián Mártir se dio por un arriero que utilizaba el camino real de la Herradura con dirección al Distrito Federal69, pero a causas sobrenaturales tuvo la necesidad de abandonar su carga en Tepetlaoxtoc. Este evento fortuito está vinculado con dos etapas históricas del municipio, la primera -como se comentó- es la presencia de grupos nómadas de origen chichimecas que no se alinean a los deseos de los gobernantes texcocanos durante el periodo prehispánico. La segunda, se refiere al auge económico que tuvo el municipio con los trabajos de arriería, mesones y bandolerismo que proliferó en la zona gracias a los caminos reales que se construyeron desde el periodo colonial, pues, resulta interesante indicar que las adversidades que tuvo que enfrentar la figura proveniente de España, que fue descargada y arriada desde el puerto de Veracruz, sorteando los peligros del tránsito hasta su arribo definitivo al centro de Tepetlaoxtoc, aunado al hecho de que se trata de la imagen de un santo masculino, cuya biografía indica que fue forzado a derramar su propia sangre como resultado a la traición contra el imperio romano, son elementos que mantienen un status quo con la identidad del vaquero tepetlaoxtoqueño; es decir, son hombres descendientes de antepasados masculinos que se jugaban la vida en el camino sobre la base de su labor de arrieros mercaderes 0 traficantes y bandoleros. Estos dos últimos eran considerados como traidores de los deseos de

\footnotetext{
${ }^{67}$ Hacia el centro de Texcoco, otros pueblos del Acolhuacán Septentrional y el Distrito Federal.

${ }^{68}$ Conocí personalmente a un gallero que apostó su carro y ganó un automóvil deportivo marca Corvett, color rojo quemado, año 2000, equipado; en un palenque regional que se realizó en el estado vecino de Tlaxcala. Al día siguiente del triunfo, el gallero salió a pasear en su automóvil nuevo para finalmente venderlo a los pocos días de haberlo ganado.

${ }^{69}$ Muy posiblemente este camino real, es la actual autopista hacia Tlaxcala vía Texcoco.
} 
la estabilidad de la nación. Además como se ha visto a lo largo de todo el ensayo, son varones que gustan de realizar actividades arriesgadas que provoquen lesiones y heridas físicas 0 simbólicas (juegos propios de la masculinidad vaquera). Lo anterior solamente son algunas de las analogías que se pueden encontrar entre la identidad contemporánea de los tepetlaoxtoqueños y la imagen de San Sebastián Mártir.

Quizá esa sea la razón por la cual el desarrollo festivo, simbólico y ritual que se realiza en la capilla de San Sebastián Mártir, reclame la asistencia de varias comunidades del municipio, frente a los festejos y solemnidades propias de la Iglesia de Santa María Magdalena. Si se revisa brevemente la biografía de esta santa, se podrá corroborar que ella era una mujer que estaba poseída por siete demonios, que la orillaban al pecado y a entregarse sexualmente, hasta que fue atrapada en fragante adulterio como lo comenta la biblia de Jerusalén:

"Los escribas y fariseos le llevaban una mujer sorprendida en adulterio, la ponen en medio y le dicen: <<Maestro, esta mujer ha sido sorprendida en flagrante adulterio. Moisés nos mandó en la Ley apedrear a estas mujeres. ¿Tú qué dices? >> Esto lo decían para tentarle, para tener de qué acusarle. Pero Jesús, inclinándose, se puso a escribir con el dedo en la tierra. Pero, como ellos insistían en preguntarle, se incorporó y les dijo: <<Aquel de vosotros que esté sin pecado, que le arroje la primera piedra. > E inclinándose de nuevo, escribía en la tierra. Ellos, al oír estas palabras, se iban retirando uno tras otro, comenzando por los más viejos; y se quedó solo Jesús con la mujer, que seguía en medio. Incorporándose Jesús le dijo: <<Mujer ¿Dónde están? ¿Nadie te ha condenado?»> Ella respondió <<Nadie, Señor.»> Jesús le dijo: <<Tampoco yo te condeno. Vete y en adelante no peques más >" (LC 8, 3-11).

En ese sentido, se tiene un santo patrón que comparte casi los mismos rasgos de identidad de los vaqueros tepetlaoxtoqueños, en comparación a una santa, es decir una mujer, que se dedicaba a la prostitución y el adulterio. Sin perder de vista que las tlacualeras (representación simbólica de las mujeres que tienen vidas sexualmente desordenadas), fueron fusiladas por su comportamiento no apropiado en la cultura local. Lo que invita a sostener que la imagen de Santa María Magdalena no es tan venerada en el municipio, por representar el desorden que caracteriza al cosmos femenino y que requiere ser reordenado con el uso de la fuerza, que es exclusiva de los hombres. 


\title{
3.0 Un acercamiento a las relaciones de parentesco.
}

A lo largo del ensayo he comentado sobre el parentesco por alianza, consanguinidad y parentesco ritual sacramental y no sacramental. En un futuro ensayo, podré describir cómo se realiza el ritual de la pedida de la novia, entrega de la dote, el rito de la alianza, y se podrá cuestionar sí la unión consuetudinaria mesoamericana, que es teóricamente considerada como el preámbulo de las alianzas matrimoniales después de varios años de convivencia, contradicen el sistema tradicional de alianzas matrimoniales en los pueblos de Tepetlaoxtoc.

En esta etapa final del ensayo, simplemente me limitaré a presentar algunas de las categorías de parentesco ritual que tuve la oportunidad de conocer, aclarando que no son las únicas que operan en el municipio.

\section{-Parentesco ritual-}

El compadrazgo definido por Pitt Rivers, se puede entender como:

\begin{abstract}
"Se deriva del concepto cristiano de parentesco espiritual, una de las tres clases de parentesco, siendo las otras dos la consanguinidad y la afinidad. El parentesco espiritual tuvo su origen en el sacramento del bautismo y se separo del parentesco natural en los comienzos de la Edad Media, al prohibírsele a los padres apadrinar a sus hijos. La base dogmática de esta decisión fue la oposición entre la generación natural, a través de la cual se transmitía el pecado de Adán, y la regeneración espiritual, mediante la cual se adquiría la gracia. Se observa una oposición similar en aquellas costumbres con arreglo a las cuales un padre 0 una madre espirituales deben remplazar a un padre 0 una madre biológicos. El parentesco espiritual implica dos tipos de lazos que crean impedimentos para el matrimonio: el lazo que se establece entre los padrinos y el ahijado y el que se establece entre los padrinos y los padres naturales, que se dan y reciben el nombre de compadres ....Los pretextos para establecer estos lazos varían. La religión católica solo reconoce hoy el parentesco espiritual el derivado de los sacramentos del bautismo y la confirmación, y solo entre los oficiantes y el bautizado y entre el padrino y el ahijado ...la costumbre popular hace caso omiso del dogma e instituye el lazo social del compadrazgo mediante ritos que a los ojos de la Iglesia no crean ninguna relación espiritual, pero que, con arreglo a la costumbre, pueden implicar una prohibición de incesto" (Pitt Rivers; 1979: 599) ${ }^{70}$.
\end{abstract}

De los primeros trabajos sobre el sistema de parentesco ritual (compadrazgo) en el territorio mesoamericano, se encuentra la obra titulada "Parentesco Ritual. Estructura y evolución histórica del sistema de compadrazgo en la Tlaxcala rural", que fue elaborada por Hugo Nutini y Betty Bell. En su libro comentan el caso de 32 tipos de compadrazgos que se desarrollaban desde la década de los 80's, teniendo en cuenta la cercanía geográfica que existe entre el estado de Tlaxcala y el municipio de Tepetlaoxtoc (Edo. de México), comentaré los parentescos rituales que conocí en mi corta estancia y los argumentaré apoyado de las investigaciones de estos dos autores.

\footnotetext{
${ }^{70}$ Subrayado mío.
} 
Nombre del parentesco

ritual

Compadre de bautismo

Compadre de conjunto musical

Compadre de fotografía

$\mathrm{Y} / \mathrm{O}$

Compadre de película

Compadre de pastel de bodas

\section{Características}

Parentesco ritual sacramental.

"Al aceptar constituirse en los padrinos de un niño, contraen ellos una serie de obligaciones económicas inmediatas, y de ahí hasta que se lleve a cabo el bautismo, deben buscar la forma de cumplirlas. Primero, sus obligaciones son: 1) vestir al ahijado (o ahijada) para el bautizo (comprar el traje bautismal para el ahijado); 2) pagar los honorarios del sacerdote y por la misa ...3) inmediatamente después de la ceremonia, dar el bolo ...como símbolo de buenos deseos para el futuro bienestar social y económico del infante; 4) dar bolo de nuevo ... a cada adulto invitado o miembro de la casa; 5) después del banquete le dan a la comadre la cabecera (regalo ceremonial de dinero ofrecido a la madre del niño, que simboliza la prosperidad que éste traerá a su familia" (Nutini;1989:70) Y después argumenta "Los padrinos y los padres contraen ciertas obligaciones económicas antes de la ceremonia bautismal en sí, pero otros lazos económicos, más importantes y duraderos se vuelven eficaces entre los actores primarios en el momento del bautismo y terminan sólo con la muerte de uno de los actores" (Nutini;1989:73)

Parentesco ritual no sacramental.

Cuando se va a realizar un rito de paso individual, particularmente unos XV años o una Boda, los anfitriones llevarán una invitación a cada persona o familia que deseen que los acompañen y funjan como testigos de ese rito de paso. Es en esos momentos cuando los anfitriones aprovechando esta ocasión, solicitan de manera formal que cierto tipo de invitado se convierta en compadre de conjunto; es decir, tendrá que buscar, pagar y asegurarse que un grupo musical asista a la celebración y toque música en vivo por un lapso de dos a cuatro horas continuas. En el remoto caso que el conjunto no llegue 0 no se hayan presentado los supuestos compadres, el parentesco ritual se dará por anulado en ese momento.

También puede existir el caso, que el invitado voluntariamente se ofrezca a costear los gastos del grupo, en este caso también se da por efectivo el compadrazgo por conjunto.

Parentesco ritual no sacramental.

En este tipo de parentesco ritual, el compadre tiene que costear los gastos y comprometerse a entregar una serie de fotografías enmarcadas, un álbum fotográfico y / 0 un video que abarque toda la celebración religiosa -si la hay- y la festividad que se desarrolla en el rito de paso individual al que se le invito, es decir: un bautismo, una confirmación, los XV años, una graduación o boda.

El compromiso del anfitrión de la fiesta, se limitará a colgar la fotografía que fue obsequiada en algún sitio de su casa.

Parentesco ritual no sacramental.

Los fuertes lazos de amistad que tienen dos varones, invita a 


\section{Compadre de pastel de XV años}

Compadre de presentación

Compadre de velación matrimonial uno de ellos a costear los gastos del pastel de bodas para el segundo varón (futuro novio). Al primero se le reconocerá como el padrino de pastel, pero debido a la gran confianza que se mantiene entre estos dos agentes, la futura pareja se dirigirá en adelante como compadre en lugar de decirle padrino.

Parentesco ritual no sacramental.

En los resultados de Nutini, él argumentó que este tipo de compadrazgo comenzaba a gestarse en la Tlaxcala rural y que no era común. Por lo tanto no hay ninguna referencia, pero ahora se puede argumentar que este tipo de compadrazgo se acuerda entre dos varones, donde el primero tendrá que costear los gastos del pastel de XV años de la hija del segundo. El favor realizado, cobrará un gran sentido de futura correspondencia simbólica y económica que se manifestará en sus lazos de amistad. Porque se debe tomar en consideración que el rito de paso de los XV años, celebra la entrada al ciclo reproductivo femenino, su presentación a la sociedad y su ingreso al mercado matrimonial.

Parentesco ritual sacramental.

"El sacramento de confirmación requiere que el niño sea patrocinado, pero por una sola persona, no por una pareja casada. Se necesita una madrina si el pequeño es mujer y un padrino si es hombre ....El pedimento inicia la relación de compadrazgo y de aquí en adelante los actores primarios se llamarán con los términos rituales apropiados de parentesco. Al estar de acuerdo en patrocinar al niño, los padrinos aceptan las siguientes obligaciones económicas: ...deben pagar los gastos de la confirmación ... deben darle un regalo al ahijado ....Los padres contraen las siguientes obligaciones económicas: 1) deben comprar la ofrenda para los padrinos ...2) los padres pueden escoger el ofrecer una pequeña comida a los padrinos y a algunos de los parientes más cercanos" (Nutini;1989:94) Y después comenta: “...el compadrazgo de confirmación puede ser considerado como una especie de compadrazgo de bautismo de segundo orden, y la selección de los compadres está condicionada por la importancia religiosa, económica y social del tipo de compadrazgo" (Nutini;1989:95).

Parentesco ritual sacramental.

"El casamiento religioso ...requiere también que los padres del novio y de la novia encuentren a una pareja que patrocinará a sus hijos en este acontecimiento ...Los padrinos deben ser aceptados por ambas partes, ya que se convierten en compadres de los dos pares de padres. Por lo tanto, el compadrazgo por casamiento, a diferencia de todos los otros tipos privado-individuales, significa una relación de tríada; padrinos-consuegros (padrinos-padres del novio-padres de la novia) mediados por la díada novio-novia ...los consuegros nunca se llaman unos a otros como tales, sino como compadres, es decir, renuncian simbólicamente a su status de suegros ante la relación dominante ...el matrimonio es el 
único caso de compadrazgo sacramental que implica una relación de tríada" (Nutini;1989:81)

Compadre por amistad

Parentesco ritual no sacramental.

"El objeto mediato del compadrazgo es la amistad entre dos individuos o familias que consideran que los vínculos y obligaciones que los unen deben ser vigorizados porque quieren hacer que su relación sea más estrecha de cómo es la amistad ...hay muy pocas obligaciones sociales, económicas o religiosas que unan específicamente a los actores primarios. No puede ser una relación social permanente y vinculadota, debido a que la ideología latente debe traducirse muy pronto en vínculos y obligaciones específicos bien delineados" (Nutini;1989:185) Y sigue: "El compadrazgo de amistad se usa como enlazamiento cuando ya no es posible hallar vecinos más allegados $u$ otras relaciones dentro de la población" (Nutini;1989:186)

En el caso de Tepetlaoxtoc, esta forma de compadrazgo es de las primeras que se establecen con personas que son vecinas de otros municipios con los que se tiene relaciones laborales o negocios permanentes.

Compadre por casamiento de
los hijos

Compadre por imagen

\section{Parentesco ritual sacramental.}

"...es una relación entre los padres del novio y los padrinos de bautismo y de confirmación del novio. En otras palabras, los padrinos de bautismo y de confirmación se convierten de facto en sus padrinos de los cónyuges de sus ahijados, y por lo tanto compadres de los suegros de sus ahijados" (Nutini;1989:104) cabe mencionar que en la actualidad, no es un requisito que sean los padrinos de bautismo los que fungirán como padrinos de velación del matrimonio.

Parentesco ritual no sacramental.

Como se comentó anteriormente, cuando surge el caso de una persona externa a la comunidad de Tepetlaoxtoc y desea recibir a la imagen de San Sebastián en su hogar, el primero tendrá que correr con los gastos de comida y bebida en el día acordado del arribo de la imagen y vecinos de Tepetlaoxtoc. Al finalizar la comida, los mayordomos que llevaron la imagen se referirán al anfitrión como compadres, pues tienen en común el mismo santo patrón.

A partir de esos momentos, se hace intercambio de datos y se espera que el anfitrión sea recibido en los próximos festejos del mes de enero en la casa de su compadre de imagen (el mayordomo).

Cabe mencionar que en todos los parentescos rituales anteriores, con excepción del compadrazgo por amistad, los compadres se referirán a los progenitores de su compadre de la misma forma. Es decir, el compadrazgo se hace extensivo al matrimonio de la primera generación ascendente de donde se estableció el parentesco ritual. A su vez, los padres del compadre se referirán de la misma forma al compadre de su hijo. 
La razón por la cual el compadrazgo por amistad no cuenta con estos privilegios, es porque se espera que el lazo de amistad recién reforzado se haga de manera permanente, ya sea costeando los gastos de un pastel de boda o XV años, el video o fotografía, conjunto musical, comida por recibir la imagen de un santo. O por adquirir un parentesco ritual de tipo sacramental, como es el caso del compadrazgo por velación, confirmación o bautismo. De la misma forma el compadrazgo por amistad, no tiene ningún tipo de responsabilidades con el otro actor y se puede disolver en cualquier momento, principalmente si no se ha buscado la ocasión para reforzarlo de manera permanente. En ese caso, se considera que no habrá tal parentesco ritual y se comienza a perder los pocos privilegios que lo mantenían.

Entre otros detalles, los derechos que se obtiene por cualquier tipo de parentesco ritual anteriormente expuesto (con excepción del compadrazgo por amistad) en el municipio de Tepetlaoxtoc, son: 1) Entre los compadres se hablarán con groserías, albures y de una manera sumamente masculina que denote su mutua confianza que los caracteriza, 2) Si un compadre tiene problemas económicos podrá solicitar el apoyo a su compadre acordando el tiempo de liquidación sin intereses, 3) En las ocasiones que se realiza un festejo familiar, los compadres pueden incorporarse sean o no invitados, 4) El compadre tiene derecho a llegar con cuantas personas lo consideres a una reunión social a la que se le haya formalmente invitado y no se hayan dado boletos, 5) En las festividades del santo patrón, se abren las botellas de alcohol por el simple hecho de haberse encontrado en ese día, también ocurre este fenómeno en ocasiones aisladas, 6) Cuando se realizan las apuestas en los palenques, el dueño de los gallos solamente se apoyará económicamente de sus consanguíneos y de los varones que compartan el parentesco ritual con él, en ninguno de los casos se recibe dinero que provenga de otras manos y 7) En caso de embriagarse en la casa de algún compadre, se tiene la seguridad de que el borracho será llevado a su solar o se podrá quedar a dormir si existe una habitación desocupada. Sin dejar de existir el tabú del incesto sobre la primera generación ascendente, descendente entre los compadres, así mismo entre ellos. 


\subsection{Reflexiones finales.}

"Los que comparten una cultura en el primer sentido, por el contrario, la <<viven〉>, la <<experimentan〉>, la <<sienten>>, aunque no necesariamente la comprendan". Roberto Varela.

Cada pueblo tiene diferentes formas de manifestar el dominio masculino sobre el femenino, algunos hacen uso de la mitología y su cosmovisión, otros realizan actividades honorables 0 mortales, en ocasiones se hace uso de ciertas herramientas que solamente los hombres saben utilizar; y en otras, simplemente se considera a la mujer como portadora de un cuerpo socialmente construido como símbolo erótico y seductivo. En el caso de la cabecera municipal del municipio de Tepetlaoxtoc; es decir, Tepetlaoxtoc centro, la práctica de la dominación masculina se comienza a evidenciar con la leyenda del arribó de la imagen de San Sebastián Mártir, porque sus pobladores sostienen que los riesgos que tuvo que sortear la imagen desde España hasta este municipio, así como la supuesta necedad de la mula de no levantarse con su carga y que de ésta apareciera la imagen de San Sebastián Mártir, es decir, un santo patrón que fue martirizado con lanzas y flechas, hace una remembranza con los primeros pobladores de la región que empleaban las misma herramientas en los momentos de cacería y guerra -como lo comenta Muñoz Camargo (2003)-. Sin mencionar, la creencia popular mesoamericana sobre el excesivo peso que adquieren las imágenes de los santos, cuando éstos eligen el sitio idóneo y la comunidad indicada para que se les adore. En suma, este contexto, ubica a San Sebastián como el santo patrón masculino del municipio sobre su homónima Santa María Magdalena. Prueba de ello, fue todo el ciclo festivo, dones, simulacros y otros eventos que se realizaron para celebrarlo.

Cabe mencionar, que el tiempo festivo del mes de enero también sirvió para acrecentar el prestigio social de muchos de los varones que participaron en estos festejos, porque: -como se observó anteriormente- las principales vías públicas se transformaron en distintos escenarios conforme se cumplían con las distintas mayordomías, los juegos masculinos y simulacros. Y para complementar el elenco, algunos hombres utilizaron a sus descendientes femeninos para participar en las diversas danzas regionales que se efectuaron como un don para el santo patrón. Dando lugar a la aparición de distintas arenas de disputa por el prestigio y reconocimiento social, porque:

"En el proceso de integración de las asociaciones, la necesidad de mostrarse atractivo a los demás para ganar su aceptación llevaría a los individuos a competir el uno contra el otro para hacer las mayores contribuciones al bienestar del grupo. En el proceso mismo de integración surgiría, así, la competencia y la diferenciación. Los victoriosos en esta primera competencia seguirían compitiendo entre sí por estatus y poder; los vencidos, 
por su parte, también continuarían compitiendo entre ellos mismos y seguirían siendo el objeto de competencia para ganar su apoyo por parte de los vencedores"

(Varela; 2006: 23-24)

Situación que invita a plantear el proyecto de la próxima investigación:

Las indagaciones de Pateman (1995), Motesinos (1999) y Bourdieu (2000) revelan, que: La mujer es considerada como portadora de un cuerpo socialmente construido como símbolo erótico y seductivo para el hombre. Y la razón se debe a su incapacidad de controlar su sangrado menstrual y su facultad innata de poder procrear lo semejante y lo diferente, como lo sostiene Héritier (2007):

"Toda la desgracia, histórica y estructural (por ser objeto de intercambio), de las mujeres proviene de que son ellas las que engendran cuerpos diferentes a los suyos"

(Héritier; 2007:107).

Razón por la cual, durante mucho tiempo la mujer había sido excluida del campo educativo, laboral y público (político), pero a medida que fueron transcurriendo las décadas y los diversos movimientos sociales feministas comenzaron a aparecer en el escenario social aunados a los avances tecnológicos sobre la anticoncepción, la mujer fue posesionándose de algunos de estos campos, como son: el laboral, el educacional y en algunos casos hasta el político. Sin embargo, el campo de la simbolización, representación, el uso exclusivo de la violencia y la apropiación de la descendencia continúan siendo los pilares que sostiene el dominio masculino. Con referente a este último punto, la aparición de los métodos anticonceptivos vinieron a liberar parcialmente la sexualidad y uso del cuerpo femenino, donde sería la mujer la que decidiera sobre tener o no descendencia y autodonaciones sexuales, pero al mismo tiempo, la sexualidad de la mujer quedó "amarrada" al dominio masculino, al permitirle a los varones tener más parejas que les proporcionarán placeres sexuales sin necesidad de mantener un control sobre ellas, y conservando el dominio sobre su esposa-madre, como lo argumenta Héritier (2007):

"...el hecho mismo de que el beneficio ya no sea exclusivo del hombre es la razón por la cual el uso de métodos anticonceptivos por parte de las mujeres es percibido por todos los fundamentalismos ...como la puerta de salida hacia la liberación femenina, ya que obligadamente acompaña a su emancipación. Ese mismo uso es también percibido por muchos hombres como una licencia suplementaria que se les ofrece para utilizar libremente el cuerpo de las mujeres" (Héritier; 2007: 253).

Siguiendo esta senda, y para complementar la investigación anterior, la próxima tiene por objetivo: Conocer las formas de construcción de la masculinidad tepetlaoxtoqueña en el ámbito público y privado, su relación con la sexualidad (apropiación de los cuerpos de las mujeres), las alianzas que buscan la reproducción del grupo, y la apropiación y resignificación de espacios 
públicos masculinos fuera de los tiempos festivos del municipio. Para esclarecer el camino y lograr este nuevo objetivo, es necesario retomar de Granados (2002), que:

"Los ordenamientos de carácter sexual se establecen conforme su determinante cultural: la división genérica de los espacios físicos y simbólicos donde los individuos se identifican. Debemos recordar que el género es la dimensión cultural que adquieren las diferencias sexuales entre hombres y mujeres, expresadas en condiciones diferenciales de vida según el sexo. Esto último es, evidentemente, resultado de una particular interpretación de lo biológico, cuya legitimación y reproducción pasa necesariamente por relaciones de poder que han permitido concebir las diferencias genéricas como destinos naturales e inmodificables" (Granados; 2002: 85)

Sobre la base de los ordenamientos de carácter sexual, se puede identificar que las labores femeninas se encuentran menospreciadas en relación al desempeño de los hombres. Ya que son éstos los que por su construcción genérica, serán objeto de la representación pública, del honor (propia de la descendencia) y de diversos tipos de intercambios con otros grupos. En ese sentido las actividades laborales femeninas (fuera del trabajo no remunerado doméstico), son infravaloradas económica y socialmente porque "se supone" que las mujeres-empleadas están respaldadas por un varón-empleado que complementa los gastos de su familia (esposa y descendencia) con los ingresos que puede aportar su esposa-empleada. De la misma forma, otra de las maneras de demostrar la masculinidad, es a través de la descendencia y las relaciones sexuales, como lo sugiere Pateman (1995):

"La manifestación ejemplar de la masculinidad es realizar <<el acto sexual»>" (Pateman; 1995: 275) Y posteriormente afirma: "...los varones pueden afirmar su masculinidad también de otros modos, pero, en las relaciones entre los sexos, se obtiene una afirmación inequívoca en el <<acto sexual»>" (Pateman; 1995: 285) ${ }^{71 .}$

Ya que, retomo de Granados (2002):

"En lo sexual, el cuerpo femenino es objeto de sujeción, requiere estar disponible al deseo masculino, adquiere un rol pasivo en la relación sexual y vínculo con la capacidad para el embarazo lo despoja de la posibilidad del placer, hay por lo tanto, una especie de asexuación de lo femenino. Mientras tanto, la masculinidad ostenta privilegios sobrevalorados, tales como el dominio, el rol activo en la relación sexual, la vedada libertad para las relaciones prematrimoniales y extramaritales, la falsa exigencia del celibato antes del matrimonio e incluso el estímulo para adquirir experiencia sexual previa, así como el "derecho" conyugal de satisfacer el deseo cuando se requiera" (Granados; 2002: 86)

Razón por la cual, los varones con otras preferencias sexuales (homosexuales) encuentran fuertes críticas y cuestionamientos sociales, al ser parte de una relación en la que no está

\footnotetext{
${ }^{71}$ Cursivas mías.
} 
definido quién tendrá el rol pasivo-dominado (penetrado) 0 activo-pasivo dominante ${ }^{72}$ (penetrador) en su relación. Además, el cuerpo masculino penetrado, será objeto de desvalorización social por adquirir el grado de feminidad que se les adjudica a las mujeres en el acto sexual. De la misma forma, se considera a la relación homosexual como una desviación del acto reproductivo, al ser un acto sexual que está imposibilitado de la capacidad de reproducir a su propio grupo.

Por ende, la definición de la masculinidad parte de lo que no se considera como masculino, es decir, el ser mujer. Así como también del aspecto negativo del ámbito femenino, como son: los varones que son penetrados por otros varones (homosexualidad) y de aquellos varones que no se han separado del universo de lo femenino (conocidos popularmente como: "hijitos de mamá"). En lo que respecta a la apropiación del cuerpo de las mujeres, o mejor dicho: las relaciones sexuales ocasionales desligadas de algún contrato o alianza entre grupos, se deben a la reciente capacidad que han adquirido las mujeres para elegir al varón con quien relacionarse, gracias a su independencia económica, su incorporación a la esfera educativa y el uso de los métodos anticonceptivos -como anteriormente se había comentado-. Siendo elementos, que le permiten a la mujer volverse la dueña de su propio cuerpo, situación que provoca, que la mujer pueda decidir sobre la posibilidad de tener relaciones sexuales fuera o desligadas del matrimonio o una alianza matrimonial, casarse o preferir la unión consuetudinaria mesoamericana, el número de hijos que se desea procrear -si es que desea hacerlo- y la capacidad de elegir, o bien, otra preferencia sexual. Esta decisión, no adquiere la misma carga crítica que la homosexualidad ejercida por los varones, puesto que éstos ven en la relación lésbica, la posibilidad de tener más parejas femeninas durante el mismo acto sexual. Porque -retomo de Ayora (2007):

"El cuerpo ...se constituye como un sitio en el que discursos, imaginarios, fantasías y utopías son articulados como estructuras de significación y de poder. LoS desplazamientos y los movimientos de ese cuerpo reciben atribuciones semánticas que nos permiten hablar de ellos como "prácticas" y éstas, a su vez, permiten a veces la reproducción" (Ayora; 2007: 91)

Al tratar de resolver la interrogante: ¿De qué manera se podría analizar la sexualidad masculina y la apropiación del cuerpo de las mujeres al interior del municipio de Tepetlaoxtoc? Una propuesta adecuada sería con la lectura que realizó Rodrigo Díaz sobre la "teoría de red de actores" (TRA) de Bruno Latour, la cual a través del concepto de redes se busca analizar procesos sociales y el tipo de relaciones que se establecen durante el desarrollo de ciertos procesos, además de generar datos acerca de los actores que participan y el tipo de relaciones

\footnotetext{
72 "En la actividad sexual con penetración, la pasividad puede ser masculina y ser sin embargo valorizada” (Héritier; 2007: 267)
} 
que establecen (como son: acción, actividad, transacciones, intercambios, sentimiento u otro tipo de conexiones) entre sus representantes. Sin embargo, uno de los problemas que identificó el mismo Latour sobre esta teoría, es que:

"...la premisa nuclear de la TRA radica en dejar de exiliar a los objetos de las prácticas humanas en general, y de las científico-tecnológicas o tecnocientíficas en particular. Ellos son tan constitutivos de la vida humana como los propios actores y acciones humanas" (Díaz Cruz; 2004: 89) Y posteriormente comenta: “...los ANH (Agentes No Humanos) están estrechamente imbricados con los sujetos de las comunidades. Para comprender este ir y venir entre unos y otros, para dar cuenta de la naturaleza híbrida del hombre, la TRA se apoya en la noción de red: <<más moldeable que la noción de sistema, más histórica que la noción de estructura, más empírica que la noción de complejidad, la idea de red es el hilo de Ariadna de estas historias entretejidas >> (Latour, 1993, 14). Las redes de actores o los colectivos suponen, entonces, las ligas, intercambios, asociaciones, desplazamientos, enrolamientos y transformaciones continúas entre los AH (Agente Humanos) y los ANH ...en contraste con las reflexiones de los científicos sociales, que cuando hablan de redes las reducen a redes de relaciones sociales entre los sujetos, grupos, partidos o naciones -siempre productos sociales-, Latour propone que las redes de actores por definición son híbridas" (Díaz Cruz; 2004: 91) ${ }^{73}$

Para demostrar, la forma en que se relacionará esta postura teórica y las propuestas del análisis de la sexualidad masculina y la apropiación de las mujeres en Tepetlaoxtoc, se presentará un pequeño ejercicio que está inspirado en una entrevista no formal previa al trabajo de campo del mes de enero. Cabe mencionar que los nombres fueron sustituidos por variables, por ser la manera más sugerida para explicar la teoría de redes:

Contexto del sujeto $\mathrm{A}$ :

El sujeto $A$ es socialmente reconocido por su capital económico en un pueblo de Tepetlaoxtoc, él está divorciado de su primera esposa $(B)$, y vivió en unión consuetudinaria mesoamericana con $C$, de esta nueva alianza nacieron dos niñas: $D$ y $E$. Sin embargo, por los problemas que originaban en el seno de sus respectivas familias, la pareja decidió separarse un tiempo (casi dos años), en lo que podían llegar a un acuerdo sobre su relación.

Durante este lapso de "tiempo libre", sucedió, según me lo comentaron los sujetos $A$ y $F$, lo siguiente:

\footnotetext{
${ }^{73}$ Paréntesis internos míos.
} 
Desarrollo del fenómeno:

Un viernes por la tarde, el sujeto $A$ se encontraba paseando en su automóvil en el centro del municipio de Tepetlaoxtoc, tras dar la vuelta, ahí encontró a su compadre $(F)$ oriundo del municipio de Chiautla del Acolhuacán Septentrional. Después de una breve plática, ambos se dirigen al centro de Texcoco para comprar algunos objetos de interés para el primero, pero al estar a unas cuantas calles de su destino, $A$ estaciona su vehículo justo en frente de los bares y antros del municipio de Texcoco. El motivo por haber hecho esta escala, se debió a que $A$ había visualizado a una señorita $(G)$ de 17 años de edad, que cubre los patrones físicos socialmente construidos sobre el cuerpo de las mujeres y que estaba con otros jóvenes esperando el momento en que le permitirían su ingreso al antro. En ese preciso momento, $A$ le chifló y la señorita volteo inmediatamente, para reconocer un rostro familiar, al cual, fue a saludar dejando a sus amigos en la fila del antro. Entre la plática que sostuvieron A y $G$, apareció la siguiente pregunta por parte de la última: ¿Este es tu carro?. Donde el vehículo había llamado la atención de la señorita y fue convencida de abandonar a su acompañante (posiblemente su novio) y a todos sus amigos (menores de edad) en la fila para el antro.

Más tarde, arribaron ( $A, G$ y $F$ ) a una tienda para comprar una serie de bebidas embriagantes que $G$ había solicitado, se subieron nuevamente al carro, prepararon las bebidas y subieron la música a "todo el volumen", mientras se dirigían a la casa de uno de los primos maternos de $A$ en las afueras del Distrito Federal.

El trío legó a altas horas de la noche y fueron obligadamente recibidos por $\underline{H \text { (primo }}$ materno de $A$ ). Durante esta reunión, $A, F, G$ y $H$ bebían con ímpetu, pero a $G$ se le comenzaban a visualizar los efectos del alcohol, hasta que llegó el momento que $A$ y $\mathrm{G}$ se subieron al vehículo, abandonando así a $\mathrm{F}$ y $\mathrm{H}$ con las botellas de alcohol que quedaban. El carro se dirigió a un terreno de siembra que está a pocos minutos de la casa del anfitrión, y como es de suponerse, hubo un acto sexual ocasional, que fue fomentado por la cantidad de alcohol que ambos agentes habían ingerido. Al finalizar, la pareja se limitó a regresar a la casa de $H$, pero solamente para recoger a $F$ y regresar al municipio de Tepetlaoxtoc, Edo. de México.

Durante todo el camino de regreso, $G$ iba con la blusa desabrochada, dormida y sus piernas entre abiertas. Situación que tuvo que remediar, al llegar a su casa a las seis o siete de la mañana.

Debo aclarar que la plática (entrevista no formal) se dio gracias a un mensaje de texto que había recibido el sujeto $A$ por parte de $G$ en ese preciso momento cuando estábamos platicando de otros temas, pero el mensaje le permitió al primer sujeto hacer gala de su virilidad masculina ante los demás varones que no estuvimos en esa reunión nocturna. En el mensaje, ella le pedía al sujeto $A$ que le comprara un par de botas y un pantalón con su cinturón para las próximas fiestas del mes de enero. A lo que respondió el primer sujeto:

"Ok, te lo compro, pero ¿qué me vas a dar a cambio?" 
Como se observó anteriormente, se presentan una serie de agentes humanos $(\mathrm{AH})$ relacionados con un solo individuo; éstos, van desde los miembros del seno familiar (ex esposa, esposa, hijas, primo materno y familia extensa) cruzando por el parentesco ritual (compadre) y los conocidos (señorita de 17 años). De la misma forma, se presentan una serie de agentes no humanos (ANH), como son: el automóvil, las bebidas alcohólicas, el volumen de la música, la distancia entre los destinos (Tepetlaoxtoc-Chiautla-Texcoco o el Distrito Federal), los lugares (centro de Tepetlaoxtoc, antro, interior del carro, casa del primo materno y terreno de siembra). Donde evidentemente todo el fenómeno no podría haberse concretado de la manera que lo hizo, sí alguno de estos agentes, principalmente los ANH no hubieran estado presentes. Porque: La primera persona puede prescindir de la compañía de su compadre, pero no así del vehículo que fue la razón, por la cual, la señorita decidió abandonar a sus acompañantes en la entrada del antro. De la misma forma, la cantidad de alcohol ingerido por los $\mathrm{AH}$ y la comodidad de estar fuera de los espacios sociales que les otorgan el grado de personas, les permitió el realizar un acto sexual ocasional. Porque se debe recordar que: Una manera inequívoca de afirmar la masculinidad es mediante el <<acto sexual >>, pues es el medio por el cual, se comprueba la potencia viril que se ha simbolizado o referido en otros eventos y circunstancias. Además, no se debe olvidar que el cuerpo de la mujer está considerado como un objeto de simbolización, territorio y apropiación del ámbito masculino. Lo que conlleva, a que la mujer -en este caso la señorita de 17 años- tenga que estar disponible para satisfacer la pulsión sexual del varón que se la apropió desde el momento en que ella se subió voluntariamente al carro. Porque, cito de Héritier:

"...todo cuerpo de mujer que no es apropiado, cuidado y defendido ...pertenece potencialmente a cualquier hombre cuya pulsión sexual debe satisfacer ...para uso sexual y búsqueda de placer, usos que, por intermedio del acto sexual, son indisociables del uso procreativo" (Héritier; 2007: 251) ${ }^{74}$

Lo interesante de este fenómeno, es que la señorita de 17 años considera que el sujeto del vehículo está en deuda con ella, y busca una compensación por los servicios sexuales prestados. Prueba de ello, fue el mensaje de texto que recibió el agente donde se le solicitaba un par de botas, un pantalón vaquero y su cinturón para usar en las festividades del mes de enero. Lo que provoca, que la señorita caiga en la categoría de prostituta sobre el principio que sugiere Pateman (1995), es decir:

"Los defensores del sexo sin amor y los seguidores de lo que una vez se dio en llamar amor libre, siempre presuponen que la relación se basa en la atracción sexual mutua entre un varón y una mujer y que implica satisfacción física mutua. El amor libre y la

\footnotetext{
${ }^{74}$ Cursivas mías.
} 
prostitución son polos diferentes. La prostitución es la utilización del cuerpo de la mujer por un varón para su propia satisfacción. No hay deseo o satisfacción por parte de la prostituta. La prostitución no busca el placer mutuo en el intercambio de los cuerpos, sino que es el uso unilateral por un varón del cuerpo de la mujer a cambio de dinero" (Pateman; 1995: 273)

Esta propuesta se comprueba, en el momento en que la respuesta del varón que se había apropiado del cuerpo de esta señorita, fue:

$$
\begin{gathered}
\text { "Ok, te lo compro, pero ¿qué me vas a dar a cambio?" } \\
\text {-como se había comentado anteriormente }
\end{gathered}
$$

Con el relato anterior, se puede confirmar la propuesta de Latour, cuando dice:

"La vida humana toda es ininteligible sin su imbricación con los ANH. De aquí la afirmación ....el concepto de <<red〉> ha tenido mucha fortuna en las ciencias sociales, permite múltiples formas de narrar de analizar los mismos fenómenos, nos hace percatarnos de cosas que no habíamos notado antes, trae nuestra atención a similitudes y analogías fecundas" (Díaz Cruz; 2004: 95) ${ }^{75}$

El uso de esta metodología, requerirá ubicar y seguir a determinadas personas durante un día laboral y / o de descanso, para conocer parte de sus redes sociales (AH) y los ANH que intervienen durante cada una de sus interacciones. $Y$ debido a que no todas las pesquisas se pueden resolver favorablemente con la "teoría de redes". La exploración se complementará, con las propuestas de Max Gluckman sobre "Ios análisis situacionales"76, por ser una postura que permite rescatar del transcurrir de la vida cotidiana, aquellos momentos o circunstancias ocasionales ubicadas en tiempos y espacios específicos, propias de los conflictos y las estabilidades temporales, en los cuales, aparecen los actores con sus nombres propios, sus funciones y ubicación social dentro de las instituciones del sistema, sus sentimientos, intereses, las conversaciones minuciosas, sus reclamos e inquietudes al sistema. En ese sentido, la situación social, ayuda a entender:

El "...cómo los actores sociales apelan, de acuerdo a cada situación o circunstancia, a normas de conducta contradictoria o inconsistente para justificar sus acciones: $<<10 s$ individuos pueden entonces tener vidas coherentes al seleccionar situacionalmente de una mescolanza de valores contradictorios, de creencias incompatibles, y de variados intereses y técnicas ...las acciones de los individuos son la unidad de análisis tanto como las estructuras sociales" (Díaz Cruz; 1998: 160-161)

\footnotetext{
${ }^{75}$ Cursivas mías.

${ }^{76}$ Retomo de Gluckman: “...una situación social es el comportamiento, en cierta ocasión, de miembros de una comunidad como tal, analizado y comparado con su comportamiento en otras ocasiones, de tal forma que el análisis revele el sistema subyacente de relaciones entre la estructura social, el ambiente físico y la vida fisiológica de sus miembros” (Gluckman; 2003: 39).
} 
Y no se debe olvidar, que -retomo de Díaz-:

“...en las situaciones sociales operan las contradicciones fundamentales de una estructura social, ya enmascarándose, renovándose o desembozándose ...una situación social no es un caso particular que ilustra o ejemplifica el funcionamiento de la estructura, pues ella no conforma un todo coherente y consistente: está sacudida por diversos valores, creencias, intereses y narrativas que se expresan y seleccionan desigual y contradictoriamente" (Díaz Cruz; 1998: 163) Y posteriormente comenta: "Para Gluckman no todo cambio supone necesariamente una transformación radical de la estructura social o de la estructura de practicas de una sociedad. Más aún, hay cambios que pueden favorecer la reproducción del sistema; cambios que consolidan el orden social y la cultura dominante ...sus nociones de <<equilibrio >> y <<estabilidad > se refieren, efectivamente .... a una integración funcional de los elementos que componen una sociedad, pero también pueden interpretarse como la capacidad de una estructura de dominación para establecer las condiciones de su reproducción y su resistencia a transformaciones más radicales" (Díaz Cruz; 1998: 166)

Esta segunda propuesta metodológica, podría ser gran utilidad en aquellos momentos en los que determinadas personas (principalmente agentes femeninos), comienzan a cuestionar los principios tradicionales propios de la relaciones entre los grupos, como son: elegir la "unión consuetudinaria mesoamericana" sobre la alianza tradicional, el uso de anticonceptivos para tener relaciones sexuales ocasionales fuera del matrimonio, la decisión personal de ser madre soltera; o comenzar a mostrar una inclinación física y social favorable a las nuevas concepciones de preferencia sexual (lesbiana u homosexual y sus variantes), entre otros fenómenos que son causa de conflictos para el sistema o de estabilidades temporales obligadas por la circunstancia. Por ende, el análisis de situación social permitiría observar las características de cada uno de los agentes humanos que intervendrían a favor o en contra, sus discursos, sentimientos, acciones, su posición de la estructura social, sus nombres propios y ocupaciones, así como, los resultados que ocurrieron en un espacio y tiempo histórico determinado.

A continuación presento algunas de las hipótesis que pueden acompañar esta nueva etapa de la investigación:

Las etnografías contemporáneas sobre el municipio de Tepetlaoxtoc y la región del Acolhuacán Septentrional, tales como: Pérez Lizaur (1975), Lechuga (2004), Rivera (2004) y Kuromiya (2006). Comentan que existe una gran tendencia a emigrar temporalmente a los municipios vecinos de Chiconcuac y Texcoco, ya sea con fines laborales, escolares, la búsqueda de alguna diversión, consumo o entretenimiento, por ser las únicas entidades del Acolhuacán Septentrional que ofrecen todos esos grandes servicios. Esa circunstancia, puede ser la razón poco 
documentada de la formación de redes sociales (amistades entre géneros iguales o diferentes), noviazgos, diferentes tipos de parentesco ritual, "uniones consuetudinarias mesoamericanas" y alianzas matrimoniales con diversos miembros de los municipios vecinos del Acolhuacán Septentrional, pues, la constante interacción e intercambio de distintos tipos de dones y mutuas invitaciones, vienen a fortalecer los lazos de amistad entre las personas y la creación de otros nuevos. Además, la imagen del vaquero norteamericano, está inscrita en el discurso masculino propia de los medios masivos de comunicación y algunas industrias culturales, circunstancia que podría provocar, que exista una fuerte admiración por parte de las mujeres, que facilite su interacción con ellas y una permisible relación sentimental.

Tomando en cuenta que socialmente los hombres son superiores a las mujeres como lo muestra la "valencia diferencial de los sexos" -propuesta por Héritier (1996), y en la medida que las mujeres tengan ciertas independencias educativas, económicas y sociales (elementos que las comienza a asemejar simbólicamente a los varones -Héritier (2007)-); podrán reclamar ciertas atenciones a su persona y dejar de depender directamente de los varones o sus esposos, porque "Es muy necesario el que la mujer que desea en serio entregarse a una profesión considere no solamente la posibilidad, sino la necesidad de permanecer soltera" (Herrasti; 2007:10). En este sentido, las familias monoparentales femeninas y los nuevos grupos domésticos de tipo matrifocal, encuentran la razón de su existencia en el territorio mesoamericano, al ya no depender de manera total del varón proveedor y representante del grupo (familia nuclear), por consiguiente, le otorga a la mujer autosuficiente la posibilidad de abandonar a su pareja masculina, con motivo de su alcoholismo, los golpes recibidos, la desobligación y el galanteo (tener amantes). Ante la disolución de la pareja, este tipo de mujer "moderna", podría descubrir la libertad del uso de su cuerpo, su capacidad de elegir con qué y cuántos tipos de hombres relacionarse, así como plantear los límites que tendrán estas nuevas relaciones. Pues con anterioridad, fueron cuestionados parcial o totalmente los pilares de la misma dominación masculina.

Considerando que: “...La masculinidad hegemónica se puede definir como la configuración de práctica genérica que encarna la respuesta corrientemente aceptada al problema de la legitimidad del patriarcado, la que garantiza (o se toma para garantizar) la posición dominante de los hombres y la subordinación de las mujeres" (Connel; 1997: 41-42). Entonces, por qué razón en los años recientes, se ha comenzado a hablar sobre la "decadencia de la masculinidad" 0 "masculinidades emergentes", como resultado del proceso de emancipación que han realizado 
una gran cantidad de mujeres que supuestamente se han logrado "liberar del yugo masculino", por el simple hecho, de que estas permiten que sus varones (pareja o esposo e hijos) realicen actividades propias del ámbito femenino, es decir, tareas domésticas que no forman parte de los roles tradicionales masculinos. Cabría la posibilidad de que no fuera realmente una decadencia 0 emergencia masculina, sino más bien, un nuevo modelo de masculinidad que se ha adaptado a las nuevas condiciones sociales.

Anexo 1.

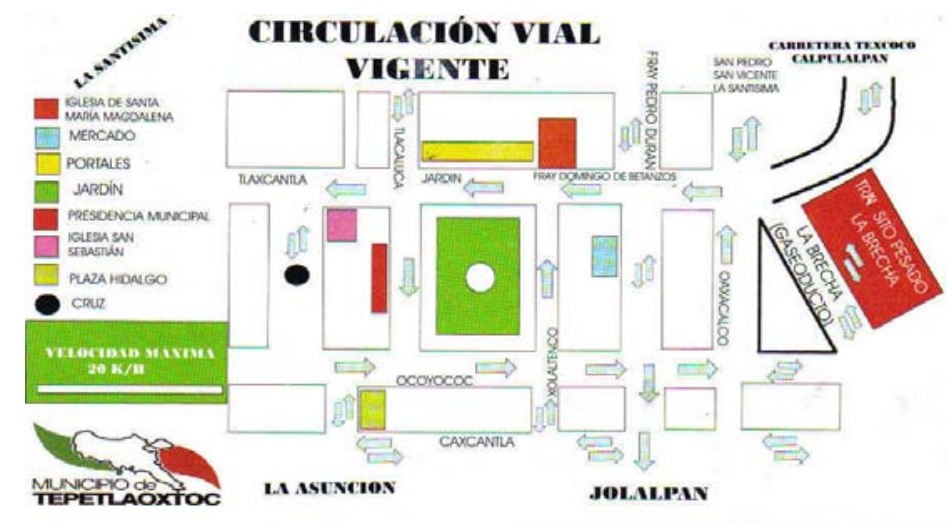

H. AYUNTAMIENTO 2006-2009.

Mapa de las principales calles del centro de Tepetlaoxtoc. 
Sinopsis del arribo de los frailes Dominicos a la Nueva España

Autor: Abel Pérez Rojas.

En 1521 Hernán Cortés solicitó al emperador Carlos I que enviara a la Nueva España hombres religiosos, principalmente de las órdenes franciscana y dominica.

El primer grupo de frailes dominicos permanecieron dos años en La Española (hoy Cuba), esperando a Fray Tomás Ortiz. Después de ese tiempo, partieron hasta su desembarcó el día 23 de junio de 1526 en las costas veracruzanas.

Desde su estancia en la isla de La Española, los dominicos iniciaron con su labor de defensa sobre la "racionalidad" de los aborígenes; es decir, oponerse a la esclavitud y al maltrato de los indígenas.

Los primeros doce dominicos que llegaron a México fueron: Tomás Ortiz (presidía el grupo), Vicente de Santa Ana, Diego de Sotomayor, Pedro de Santa María, Justo de Santo Domingo, Pedro Zambrano, Gonzalo Lucero, Bartolomé de Calzadilla, Domingo de Betanzos ${ }^{77}$, Diego Ramírez, Alonso de las Vírgenes y Vicente de las Casas.

Por diversas circunstancias y en muy poco tiempo, solamente sobrevivieron tres religiosos dominicos en todo el territorio americano. Lo que provocó que para el año de 1528 llegará la segunda expedición de estos frailes, que estaba compuesta por 24 sacerdotes y era presidida por fray Vicente de Santa María.

Con esta segunda incursión, se comenzó con la construcción de eremitorios y monasterios para dominicos en la ciudad de México (Coyoacán), en los actuales municipios de Chimalhuacan y Tepetlaoxtoc en el Estado de México, Oaxaca y en Guatemala. Cabe mencionar, que adjuntas a las construcciones se establecen casas-escuelas en las cuales se alfabetizaba, catequizaba y enseñaba diversos oficios a los aborígenes. Impulsando así diversos escritos en español o en distintas lenguas autóctonas.

Linkografía:http://www.sabersinfin.com/index.php?option=com content\&task=view\&id=507\&ltemid=89

\footnotetext{
${ }^{77}$ Cursivas mías.
} 
Anexo 3.

Breve historia del ruedo en América.

Durante la época del imperio romano, se edificaron varios coliseos en las principales ciudades de Europa, resaltando por sus características el Coliseo en Roma. Cabe mencionar, que la idea de los anfiteatros, fue retomada a su vez, por otras comunidades que incorporaron la práctica durante sus festividades anuales. Sin embargo, el principio en todos los casos era siempre el mismo; es decir, estas graderías, fueron construidas con la finalidad de presentar: pelea entre gladiadores, representaciones históricas de batallas memorables para el ejército romano, combate cuerpo a cuerpo o contra fieras que eran traídas desde distintas partes del imperio.

Una vez que se fragmentó el imperio, se continuó con este tipo de festividad incorporando nuevos elementos propios a cada región. En ese sentido, aparece la fiesta taurina o corrida de toros española, la cual rescata parte de la arquitectura de los anfiteatros romanos, como se verá a continuación:

"Las plazas de toros, también conocidas como cosos taurinos y anteriormente como circos taurinos, son recintos cerrados, generalmente circulares y descubiertos, donde se celebran las corridas de toros. Sus estilos arquitectónicos son diversos de acuerdo al mayor o menor grado de antigüedad, si bien en la actualidad predominan las de estilo neomúdejar. Tienen su origen en la Europa antigua. Principalmente consiste en un anfiteatro cerrado de forma aproximadamente circular con graderías y servicios que rodean un espacio central en donde se realiza el espectáculo taurino, llamado ruedo 0 redondel -un terreno de tierra batida (arena o albero)- rodeado de un callejón en donde se preparan y refugian los toreros y subalternos. El callejón está separado del ruedo por una estructura o pared, generalmente de madera y de aproximadamente 140 centímetros del altura, que posee estribos hacia el ruedo y en ocasiones también hacia el callejón para facilitar el acceso de los alternantes en caso de emergencia. Dispone de portones de acceso batientes para la entrada y salida de los participantes (puerta de cuadrilla) y de los toros (puerta de toriles y de arrastre) aunque la cantidad y disposición de estos accesos varía de un recinto a otro.

También hay plazas de toros portátiles, construidas a base de una estructura metálica 0 de otro tipo para aislar un espacio y que se montan y desmontan tradicionalmente en pueblos y ciudades que no disponen de una plaza fija."

Linkografía: http://es.wikipedia.org/wiki/Plaza de Toros\#Historia

Con esta noción, en España se edifican los primeros palenques que continúan presentando el mismo principio arquitectónico del coliseo, pero con la diferencia de que combatirán gallos que eran traídos del lejano oriente en lugar de personas. Tradición que llegó a América gracias a la conquista militar y evangélica por parte del imperio español. Cabe mencionar que la tradición taurina en el territorio nacional, sufre nuevamente una modificación después de la independencia 
de México, al incorporar la imagen del charro ${ }^{78}$ que solicita permiso ya sea a un sacerdote 0 un representante simbólico del que fue el Virrey español para comenzar la fiesta brava. Otro caso de aculturación de este fenómeno, ha sido la charrería y el jaripeo ${ }^{79}$ que se continúa practicando en la actualidad en algunas regiones del país.

\footnotetext{
${ }^{78}$ Jáuregui comenta que los mariachis retoman la indumentaria del charro, como eslogan de su oficio: "El efecto simbólico valía anacronismos y sinsentidos: ataviados de charros se mostraban como un grupo musical con clara raigambre en esta tierra; se manifestaban como el prototipo del mestizo y, por lo tanto, se apartaban de los indígenas y los negros. Se integraban, así, al paradigma internacional que incluía, entre otros, al cowboy norteamericano, al guacho argentino" (Jáuregui 2004: 252).

${ }^{79}$ Alude a la monta de toros. Cabe recordar que existe una gran analogía entre Jaripeo y Rodeo, la diferencia que se puede enunciar, es que el Rodeo es una deformación norteamericana del jaripeo mexicano.
} 
Anexo 4.

\section{Validan apuestas en carreras de caballos y peleas de gallos}

Ministros aseguran que permisos de Segob para que se realicen juegos de dados no violan la ley; una mayoría simple de ministros, es decir seis, con el voto en contra de otros cuatro, ante la ausencia en el último punto de Mariano Azuela, se pronunció también por declarar inconstitucional el juego de la ruleta

Carlos Avilés

El Universal

Viernes 19 de enero de 2007

La Suprema Corte de Justicia de la Nación (SCJN) resolvió que es constitucionalmente válido el cruce de apuestas que se realiza en los espectáculos de carreras de caballos en escenarios temporales, conocidas como parejeras, y en peleas de gallos, que tienen lugar sólo en ferias regionales.

El máximo tribunal del país también resolvió que las autorizaciones que otorga la Secretaría de Gobernación (Segob) para que haya juego de dados con apuestas en las ferias regionales tampoco viola la Constitución, pues esta modalidad está permitida en la Ley de Juegos y Sorteos.

En cambio, el alto tribunal concluyó que el juego de naipes en las ferias sí es violatorio, por lo que la Segob no puede otorgar permisos para que esta actividad se lleve a cabo, por ser un espectáculo que se basa en un juego prohibido por la ley en la materia.

Fuente: Periódico "El Universal", 19 de enero 2007.

Linkografía: http://www.el-universal.com.mx/nacion/147594.html 


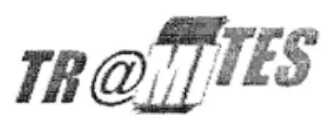

\begin{tabular}{|c|c|c|}
\hline \multirow{4}{*}{\begin{tabular}{|c} 
PERMISO PARA PEL \\
(Permiso para peleas de gall \\
Enviar a un amigo $₫$ \\
¿Quién io presenta y en qué casos? \\
Personas Fisicas y Morales \\
Permisos para efectuar cruce de apuestas en peleas \\
de gallos y rifas de nùmeros
\end{tabular}} & \multirow{2}{*}{\multicolumn{2}{|c|}{ _EAS DE GALLC }} \\
\hline & & \\
\hline & \multicolumn{2}{|l|}{ Medio(s) de presentación } \\
\hline & $\begin{array}{l}\text { No. Original(es) } \\
1 \text { (uno) }\end{array}$ & $\begin{array}{l}\text { No. Copia(s } \\
\text { 2(dos) }\end{array}$ \\
\hline $\begin{array}{l}\text { Dependencia u organismo responsable del trámite } \\
\text { Secretaria de Gobernación } \\
\text { Dirección General Adjunta de Juegos y Sorteos } \\
\text { Hamburgo } 135,12 \\
\text { Colonia Juárez } \\
\text { CP 06600, México, D. F. }\end{array}$ & \multicolumn{2}{|c|}{$\begin{array}{l}\text { ¿Qué información se requiere? } \\
\text { Nombre Solicitante, RUPA, Nacionalidad, R } \\
\text { Domiclilio, Teléfono, Nombre del RRepresenta } \\
\text { Legal, Teléfono, Estado, Municipio, Comunid } \\
\text { Domicilio del palenque, Descripción de vias } \\
\text { acceso y ubicación. }\end{array}$} \\
\hline $\begin{array}{l}\text { Otras oficinas en donde puede realizarse el trámite } \\
\text { Seleccione con doble click }\end{array}$ & \multicolumn{2}{|l|}{ ¿Qué documentos se requieren? } \\
\hline 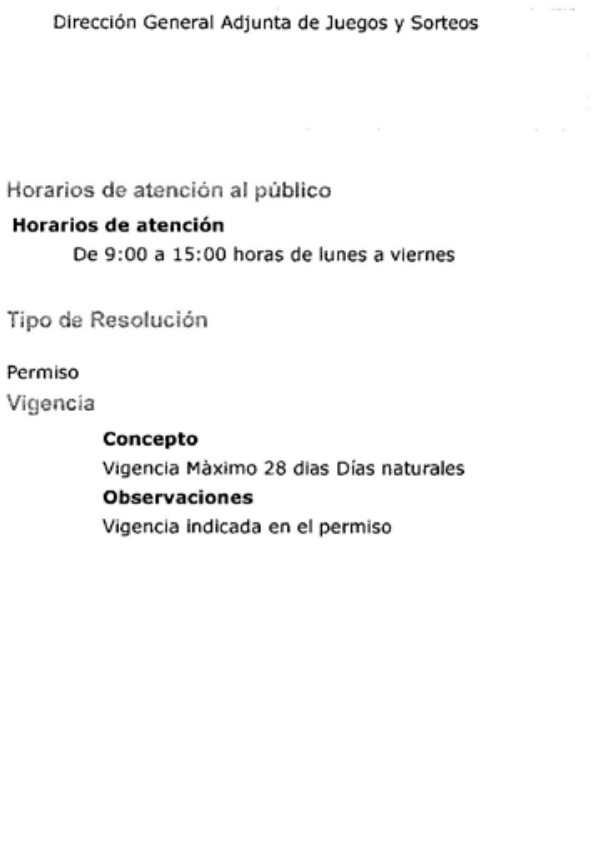 & \multicolumn{2}{|c|}{ 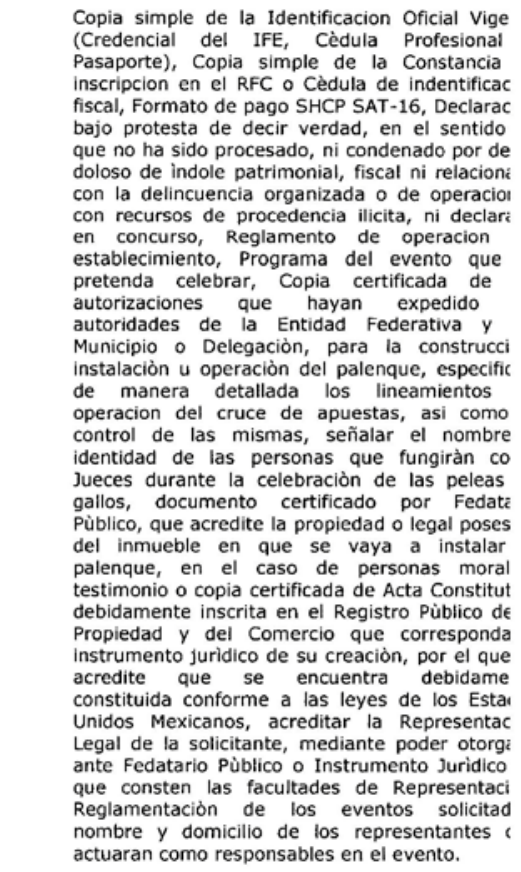 } \\
\hline & $\begin{array}{l}\text { No. Original(es) } \\
1 \text { (uno) }\end{array}$ & $\begin{array}{l}\text { 0. Copia(s) } \\
1 \text { (uno) }\end{array}$ \\
\hline
\end{tabular}




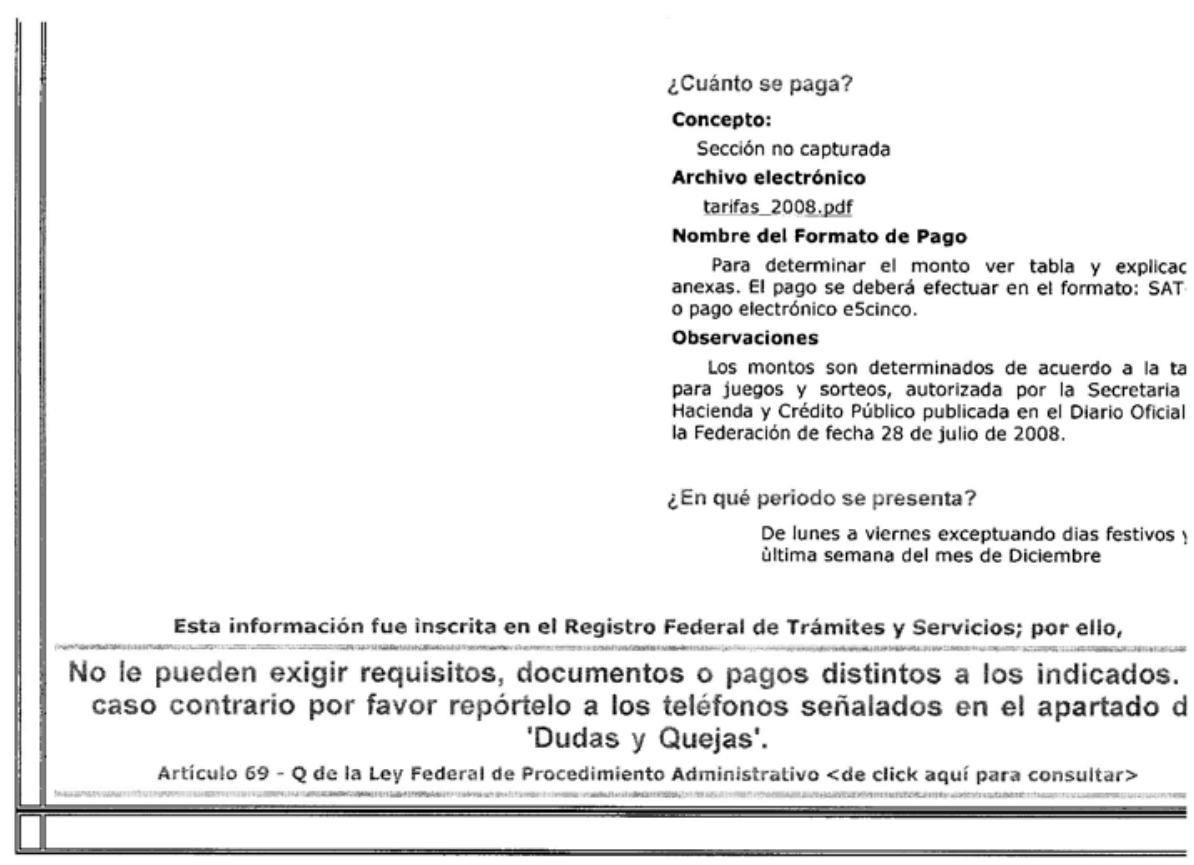


Anexo 5.

Incidentes en el simulacro de la mayordomía de los arrieros.

De los incidentes trágicos que caracterizó a esta representación, fue el caso de un jinete que representaba a la gente del pueblo, pero que estaba embriagado. El efecto del alcohol provocó que arrancará su caballo, pero él todavía no se había sentado correctamente; entonces el animal lo transportó a media silla durante varios metros. El jinete por jalar el freno hacia el lado derecho a manera de no caerse del caballo, provocó que el animal siguiera corriendo, pero ahora en dirección a la gente que se había conglomerado para ver el espectáculo en el lado derecho de la calle Tlaxcantla. El animal término por derribar al jinete, se subió completamente a la banqueta y se desbocó contra el público. Alguna persona del público tomó el freno del animal y lo obligó a detenerse completamente.

En esos precisos momentos, yo estaba del otro lado de la calle platicando con César Almeraya que es compadre de fotografía de José Manuel Delgadillo (recordar la fotografía 4), su esposa Gloria ¿?, Antonio ¿? y un señor que le dicen: "El perro". Todos los anteriores, son oriundos del pueblo de Jolalpan. Lo importante de esto, es que aparentemente todos conocían o estaban vinculados parentalmente (alianza, consanguinidad o parentesco ritual) con el accidentado, porque: a) Fueron los primeros en socorrerlo, b) Le retiraron la pistola que estaba todavía recargada, c) Comenzaron a auxiliarlo y tranquilizarlo (porque exigía su pistola para matar al caballo), y d) El accidentado les habló por sus nombres y con dificultad contenía su violencia. Al instante se aproximaron dos jinetes (un arriero y una tlacualera) que conocían al accidentado, quienes se aseguraron que estuviera bien, la tlacualera recogió el arma y el arriero retiró al caballo de la calle. Después dirigiéndose a la esposa de César (Gloria), le dijo con una voz muy molesta:

¡Comadre, háblale a la esposa de este pendejo!

Y después, subiendo el caballo hasta la banqueta le grito al varón embriagado:

¡Hijo de la chingada, ¿Cómo se te ocurre?, ¿Qué no piensas?!

El accidentado al no poder contestar a las agresiones o no entender que era lo que estaba pasando, se lo llevaron cargando entre Antonio ¿? Y "el perro" a su casa para que descansará y se repusiera de sus heridas menores. Después de que retiraron al herido, la Sra. Gloria ¿? (esposa de César Almeraya), dijo:

¡¿Por qué se tenía que caer justo enfrente de donde estamos?!

¡¿Por qué justo enfrente?! 
Afortunadamente no se reportó ningún herido a consecuencia del caballo desbocado. Todo quedo en el susto y la impresión que produjo en ambos lados de la calle este animal.

Tanto el jinete como el público, tuvieron la fortuna de que el primero (el jinete accidentado), era el último de los jinetes que perseguían a los bandidos. Pues de haber sido el que encabezará o que fuera a la mitad de su cuadrilla, su posición le hubiera provocado que más de ocho caballos a galope y sus respetivos jinetes le pasaran por encima de su cuerpo, que se mantuvo extendido a lo ancho de esta calle empedrada hasta que fue auxiliado. 


\section{BIBLIOGRAFÍA:}

ALSIVAR, Armando.

SIA Poemas sobre Tepetlaoxtoc.

AUGÉ, Marc.

2000 Los <<no lugares >> espacios del anonimato. Una antropología de la sobremodernidad, Barcelona, GEDISA.

AYORA DIAZ, Steffan Igor.

2007 "El cuerpo y la naturalización de la diferencia en la sociedad contemporánea", colección Nueva Antropología. La antropología en cuestión: cinco ensayos temáticos y un estudio de caso, Vol. XX, No. 67, mayo, México, CM-CONACYT-UNAM, pp. 89-118.

BALANDIER, George.

1994 El poder en escena. De la representación del poder al poder de la representación. Barcelona, PAIDOS.

BIBLIA DE JERUSALÉN.

1998 Desclée de Brouwer Bilbao, España.

BOURDIEU, Pierre.

1991 La distinción. Criterios y bases sociales del gusto, Madrid, TAURUS.

2000 La dominación masculina, Barcelona, ANAGRAMA.

CAMPBELL, Federico.

2004 "El narcotraficante" en FLORESCANO, Enrique. Mitos mexicanos. México, TAURUS: pp. 375-383.

CAMPOS GARCÍA, Margarita.

1973 Escuela y comunidad en Tepetlaoxtoc, colección SEPSETENTAS, no. 89, México, Biblioteca SEP.

CANDO MORALES, Mariano.

1999 Tepetlaoxtoc. Monografía municipal. México, Gobierno del Estado de MéxicoAMECROM-Instituto Mexiquense de Cultura.

CASTELLS, Manuel.

1982 "El mito de la cuestión urbana" y "Los medios sociales urbanos" en La cuestión urbana, México, Siglo XXI, pp. 95-106 y 118-137.

COHEN, Abner.

1979 "Antropología política: el análisis del simbolismo en las relaciones de poder" en LLOBERA, José R. (comp.) Antropología política, España, ANAGRAMA, pp. 55-82.

CONNEL, Robert W.

1997 "La organización social de la masculinidad" en VALDES, Teresa y José OLAVARRÍA. Masculinidad/es: poder y crisis, ISIS-FLACSO: Ediciones de las Mujeres no. 24, pp. 3148. 
CORTES, Hernán.

2003 Cartas de relación. España, PROMOLIBRO.

DaMATTA, Roberto.

2002 Carnavales, malandros y héroes, México, FCE.

DA SILVA CONCHA, Devanir.

2004 "Masculinidad y café con piernas. ¿Crisis, reacomodo o auge de una "nueva" masculinidad?", colección Gazeta de antropología, no. 20, España, Universidad de Granada.

DE ALBA CASILLAS, Diego.

2004 Tesis de maestría: Las ferias: procesos simbólicos y económicos que actúan como integradores de una región. Feria Nacional de San Marcos, Aguascalientes, Ags., y San Miguel el Alto, Jalisco. México, UAM.

DE LA GARZA, María Luisa.

2008 Pero me gusta lo bueno. Una lectura ética de los corridos que hablan del narcotráfico y de los narcotraficantes. México, PORRUA.

DÍAZ CRUZ, Rodrigo.

1998 Archipiélago de rituales. Teorías antropológicas del ritual, colección ANTHROPOSUAM, no. 33, México, UAM.

2004 "Contra el exilio de los objetos. Un acercamiento a la teoría de red de actores" en LUNA, Matilde. Itinerarios del conocimiento: formas, dinámicas y contenidos. Un enfoque de redes, colección ANTHROPOS-IIS-UNAM, no. 13, México, UNAM.

DÍAZ DEL CASTILLO, Bernal.

2003 Historia verdadera de la conquista de la Nueva España, Vol. I. España, PROMOLIBRO.

DÍAZ DIEGO, José.

2006 "La I-lógica de los géneros: metrosexuales, masculinidad y apoderamientos" colección Revista de Antropología Iberoamericana, enero-febrero, año 1, Vol. 1, no. 001, Madrid, Antropólogos Iberoamericanos en Red. pp. 157-167.

DUHAU, Emilio y Angela GIGLIA.

2004 "Espacio público y nuevas centralidades. Dimensión local y urbanidad en las colonias populares de la ciudad de México" en Papeles de población, no. 41, México, CIEAP/UAEM, pp.167-194.

2008 Las reglas del desorden. Habitar en la metrópoli, México, UAM-Siglo XXI.

DURKHEIM, Emile.

1995 Las formas elementales de la vida religiosa, México, Ediciones Coyoacán.

FLORES MARTOS, Juan Antonio.

2005 "Hacia una teoría cultural del trauma y la violencia cotidianas en el puerto de Veracruz" colección Nueva Antropología. Tierra quemada: violencias y culturas en America Latina, Vol. XX, no. 65, mayo-agosto, México, Nueva Antropología A. C. pp. 93-112. 
FOUCAULT, Michel.

2007 Historia de la sexualidad 1. La voluntad de saber. España, Siglo XXI.

GARCÍA CANCLINI, Néstor y Ernesto PIEDRAS FERIA.

2008 Las industrias culturales y el desarrollo de México, México, FLACSO-Siglo XXI.

GARMA NAVARRO, Carlos.

2008 "Las masculinidades en la música cristiana", colección: VERSIÓN, no. 21, México. pp. 83-100.

GEERTZ, Clifford.

1987 "Ethos, cosmovisión y el análisis de los símbolos sagrados", "Centros, reyes y carisma: Una reflexión sobre el simbolismo del poder" $Y$ "Juego profundo: notas sobre la riña de gallos en Bali" en La interpretación de las culturas, México, GEDISA, pp. 118-130,147171 y $339-372$.

GLUCKMAN, MAX

2003 "Análisis de una situación social en Zululandia moderna", colección BRICOLAGE, año 1, no. 1, enero-marzo, México, UAM, pp. 34-49. Traducción Rocío Gil y José Luis Lezama.

GODELIER, Maurice.

1997 "Simbológica del cuerpo, orden social y lógica de poder" en MARIE-ODILE, Marion. Simbológicas, México, Plaza y Valdés, S. A. de C. V.-CONACYT, pp. 17-37.

1998 El enigma del don, Barcelona, PAIDOS BÁSICA.

GÓMEZ SUÁREZ, Agueda y Marinella, MIANO BORUSSO.

2006 "Dimensiones simbólicas sobre el sistema sexo/género entre los indígenas zapotecas del Istmo de Tehuantepec (México)", colección Gazeta de antropología, no. 22, España, Universidad de Granada.

GRANADOS COSME, José Arturo.

2002 "Orden sexual y alteridad: La homofobia masculina en el espejo" en colección Nueva Antropología, septiembre, Vol. XVIII, no. 61, México, Nueva Antropología, A. C. pp. 7997.

GUTIÉRREZ, Alejandro.

2007 Narcotráfico. El gran desafío de Calderón. México, PLANETA.

HALL, Edward.

1998 La dimensión oculta, México, Siglo XXI.

HEMEROTECA.

2007 El Universal, viernes 19 de Enero, México.

HERRASTI, Alicia.

2007 Liberación femenina, colección E.V.C., número 617, México. EVC. 
HÉRITIER, Francoise.

1996 "La valencia diferencial de los sexos ¿Se halla en los cimientos de la sociedad?" y "La sangre del guerrero y la de las mujeres" en Masculino / Femenino. El pensamiento de la diferencia. Barcelona, ARIEL, pp. 15-28 y 205-232.

2007 Masculino / Femenino II. Disolver la jerarquía, México, FCE.

JÁUREGUI, Jesús.

2004 "Tres de mariachi y una mariachada" en FLORESCANO, Enrique. Mitos mexicanos. México, TAURUS, pp. 251-258.

KIMMEL, Michael S.

1997 "Homofobia, temor, vergüenza y silencio en la identidad masculina", en VALDES, Teresa y José OLAVARRÍA. Masculinidad/es: poder y crisis, ISIS-FLACSO: Ediciones de las Mujeres no. 24, pp. 49-62.

KUROMIYA, Aki.

2006 Tesis de Maestría: Salir adelante: conflicto, armonía y la práctica local del progreso en Santo Tomas Apipilhuasco, Estado de México. México, Universidad Iberoamericana.

LACARRIEU, Mónica.

2007 "Una antropología de las ciudades y la ciudad de los antropólogos", colección Nueva Antropología. La antropología en cuestión: cinco ensayos temáticos y un estudio de caso, Vol. XX, No. 67, mayo, México, CM-CONACYT-UNAM, pp. 13-39.

LAMAS, Marta.

2007 "Complejidad y claridad en torno al concepto de género" en GIGLIA Angela-Carlos GARMA-Ana Paula de TERESA. ¿Adónde va la antropología?. México, UAM-JP, pp. 83108.

LEACH, Edmund.

1985 Cultura y comunicación. La lógica de la conexión de los símbolos, Madrid, Siglo XXI.

LECHUGA PAREDES, Rubén Esteban.

2004 Tesis de Maestría: Tlaltecahuacan: lugar de hombres con tierras divididas. Continuidad y cambio en el núcleo agrario de un ejido en el Acolhuacán. México, Universidad Iberoamericana.

LÉVI-STRAUSS, Claude.

1985 Las estructuras elementales del parentesco. México, ORIGEN / PLANETA.

1986 Antropología estructural. España, PAIDOS BÁSICA.

1991 "La familia" en Polémica sobre el origen y la universalidad de la familia. España, ANAGRAMA.

Linkografía:http://mx.answers.yahoo.com/question/index?qid=20060921095056AAQQV7d

Linkografía: uww.cholonautas.edu.pe

Linkografía: http://www.cofemer.gob.mx/BuscadorTramites/DatosGenerales.as

Linkografía: http://debnosus.blogspot.com/2007/01/la-feria-del-pulque.html 
Linkografía: http://www.el-universal.com.mx/nacion/147594.html

Linkografía: http://www.googleearth.com

Linkografía: http://es.wikipedia.org/wiki/Plaza de Toros\#Historia

Linkografía: http://www.youtube.com

LÓPEZ AUSTIN, Alfredo.

1985 La educación de los nahuas, Vol. 1, SEP Cultura, México, Ediciones El Caballito y Dirección General de Publicaciones.

MAUSS, Marcel.

1971 "Ensayo sobre los dones" en Sociología y antropología, Madrid, TECNOS, pp. 163-176.

MENDOZA ONTIVEROS, Martha Marivel.

2004 Tesis de doctorado: La perennidad del don. El don y sus transformaciones en el Acolhuacán. México, UAM.

MILLÁN, René.

2008 "Sociedad compleja: ¿Cómo se integra?", colección DESACATOS, no. 28, Septiembrediciembre, México, CIESAS-CLACSO, pp. 69-87.

MINTZ, Sydney W. Eric R. WOLF.

1971 "Análisis del parentesco ritual (Compadrazgo)", colección WAYKA, no. 45, Cuzco, Perú.

MONTESINOS, Rafael.

2005 Masculinidades emergentes, México, PORRUA-UAM.

MONTESINOS, Rafael y Griselda MARTÍNEZ.

1999 "Erotismo y violencia simbólica. Un ensayo sobre el proceso civilizatorio", colección Iztapalapa, no. 47, México, UAM, pp. 249-269.

MUÑOZ CAMARGO, Diego.

2003 Historia de Tlaxcala, España, PROMOLIBRO.

NIETO, Raúl.

1998 "Experiencias y practicas sociales" en Néstor GARCÍA CANCLINI. Cultura y comunicación en la ciudad de México, Vol. 1, México, GRIJALBO-UAM, pp. 235-277.

NUTINI, Hugo y Betty BELL.

1989 Parentesco ritual. Estructura y evolución histórica del sistema de compadrazgo en la Tlaxcala rural. México, FCE.

NESTI, Arnaldo.

2007 "Presentazione" en TROMBETTA, Pino Lucá y Simona SCOTTI. L'albero della vita. Feste religiose e ritualitá profane nel mondo globalizzato, colección: Nouva serie, no. 3, Italia, Firenze University Press, pp.1-9. 
OCHOA RIVERA, Teresa.

2008 "La dominación masculina en el sistema tradicional de cargos: el caso de San Jerónimo Amanalco, municipio de Texcoco, México" en Notas para el debate. IBERO Forum, Primavera Tomo 4, Vol. 1, México, Universidad Iberoamericana.

OLAVARRÍA, María Eugenia.

2002 "De la casa al laboratorio. La teoría del parentesco hoy en día", colección ALTERIDADES, año 12, no. 24, México, UAM, pp. 99-116.

2007 (Coord.) Simbolismo y poder, México, PORRUA-UAM.

2008 "Poder, mercado y tecnología del parentesco contemporáneo", colección Antropología experimental, No. 8, Texto 17, España, Universidad de Jaén, pp. 235-244.

ORTNER, Sherry B.

1995 "Resistance and the Problem of Ethnographic Refusal" en Comparative Studies in society and history, Vol. 37, pp. 173-193.

PADILLA PINEDA, Mario.

2000 Ciclo festivo y orden ceremonial, México, Colegio de Michoacán.

PATEMAN, Carole.

1995 El contrato sexual, colección: ANTHROPOS-UAM, no. 87, México, UAM.

PAYNO, Manuel.

2004 Los bandidos de Río Frío, México, PORRUA.

PÉREZ LIZAUR, Marisol.

1975 "Prologo", "Introducción", "Un pueblo atípico: Tepetlaoxtoc" y "Algunas conclusiones e hipótesis" en Población y sociedad. Cuatro comunidades del Acolhuacán. México, CISINAH-SEP-INAH, pp. 7-28, 145-180 y 181-198.

PÉREZ ROJAS, Abel.

S/A "Sinopsis del arribo de los frailes Dominicos a la Nueva España" en Linkografía: http://www.sabersinfin.com/index.php?option=com content\&task=view\&id=507\&ltemi $\quad d=89$

PITT-RIVERS. Julian.

1979 "Seudoparentesco" en David, SILLS. Enciclopedia Internacional de las Ciencias Sociales, Vol. VII, Madrid, Aguilar, pp. 596-601.

1997 "Un ritual de sacrificio: la corrida de toros española", colección ALTERIDADES, año 7, no. 13, México, UAM, pp. 109-115.

PORTAL, María Ana.

1997 Ciudadanos desde el pueblo, México, UAM-CONACULTA.

REDFIELD, Robert.

1982 "El calpulli-barrio en un pueblo mexicano actual" en colección Nueva Antropología, los estudios de parentesco. Año 5, No. 18, México, Nueva Antropología A. C. pp. 85-97. 
RIVERA PÉREZ, Roberto.

2004 Tesis de Licenciatura: En búsqueda de la endogamia de barrio. Estudio realizado en la Delegación Milpa Alta, D. F. y el municipio de Texcoco, Estado de México. México, UAM.

2008 "Sombreros, capotes, espuelas y navajas. Análisis del espacio y un acercamiento simbólico de los rodeos, jaripeos y palenques en un municipio del noreste del Estado de México", colección Gazeta de antropología no. 24, España, Universidad de Granada.

2009 "¿Donación versus autodonación en Mesoamérica?", colección Gazeta de antropología, no. 25, España, Universidad de Granada.

ROBICHAUX, David.

2003 "La formación de la pareja en la Tlaxcala rural y el origen de las uniones consuetudinarias en la Mesoamérica contemporánea: un análisis etnográfico y etnohistórico" en El matrimonio en Mesoamérica ayer y hoy, colección: Unas miradas antropológicas. México, Universidad Iberoamericana, pp. 205-236.

SÁNCHEZ VALDÉS. María Teresa.

1997 "La fiesta religiosa de Corpus Cristi", colección Expresión Antropológica. No. 4-5, México, Nueva Época, pp. 35-41.

SCOTT, James C.

2000 Los dominados el arte de la resistencia. México, ERA.

SPIER, Leslie.

1975 "Las invenciones y la sociedad humana. La medición del tiempo y el calendario" en SHAPIRO, Harry, L. Hombre, cultura y sociedad., México, FCE, pp. 343-347.

STOLCKE, Verena.

1996 "Antropología del género. El cómo y el por qué de las mujeres" en J. Prat \& A. Martínez (eds), Ensayos de Antropología Cultural. Homenaje a Claudio Esteva-Fabregat, Barcelona, Editorial Ariel, S. A. pp. 335-344.

THOMPSON, John B.

2003 "Violencia simbólica", colección BRICOLAGE, año 1, no. 2, mayo-junio, México, UAM, pp. 62-73.

TINAJERO, Omar.

2002 Imágenes del silencio. Iconología de Tepetlaoztoc, México, Centro de estudios del Acolhuacán Santo Domingo Portacoeli.

TOLALPA ESCORCIA, Eva Patricia.

2005 "La masculinidad en el nuevo contexto cultural: un invitado ausente" en MONTESINOS, Rafael. Masculinidades emergentes, México, PORRUA-UAM, pp. 181-216.

TOVAR ESQUIVEL, Enrique.

2005 Tesis de maestría: De la coerción simbólica religiosa y sus respuestas. Imagen y poder en la Nueva España, México, UAM. 
VARELA, Roberto.

2005 Cultura y poder. Una visión antropológica para el análisis de la cultura política, colección ANTHROPOS-UAM, no. 40, México, UAM.

2006 Expansión de sistemas y relaciones de poder. Antropología política del Estado de Morelos. México, UAM.

VALLE PEÑA, Perla.

1993 Memorial de los indios de Tepetlaoztoc o códice Kingsborough. A cuatrocientos cuarenta años., México, INAH.

VARGAS CETINA, Gabriela

2007 "Tiempo y poder: la antropología del tiempo", colección Nueva Antropología. La antropología en cuestión: cinco ensayos temáticos y un estudio de caso, Vol. XX, No. 67, mayo, México, CM-CONACYT-UNAM, pp. 41-64.

VENDRELL FERÉ, Joan.

2005 "Victimas, victimarios, vengadores y cronistas: sobre la violencia sexual y representación en Morelos", colección Nueva Antropología. Tierra quemada: violencias y culturas en America Latina, Vol. XX, no. 65, mayo-agosto, México, CM-CONACYT-UNAM, pp. 131148. 


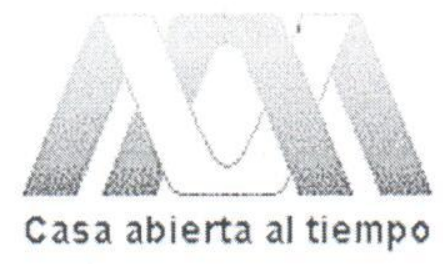

UNIVERSIDAD AUTÓNOMA METROPOLITANA

UNIDAD IZTAPALAPA

DIVISIÓN DE CIENCIAS SOCIALES Y HUMANIDADES

POSGRADO EN CIENCIAS ANTROPOLÓGICAS

MASCULINIDAD Y FIESTA EN EL TEPETLAOXTOC

DEL ACOLHUACÁN SEPTENTRIONAL.

ESPACIOS DE VIRILIDAD AL INTERIOR DE UN MUNICIPIO DEL

ESTADO DE MÉXICO.

Roberto Rivera Pérez

Tesina de Maestría en Ciencias Antropológicas

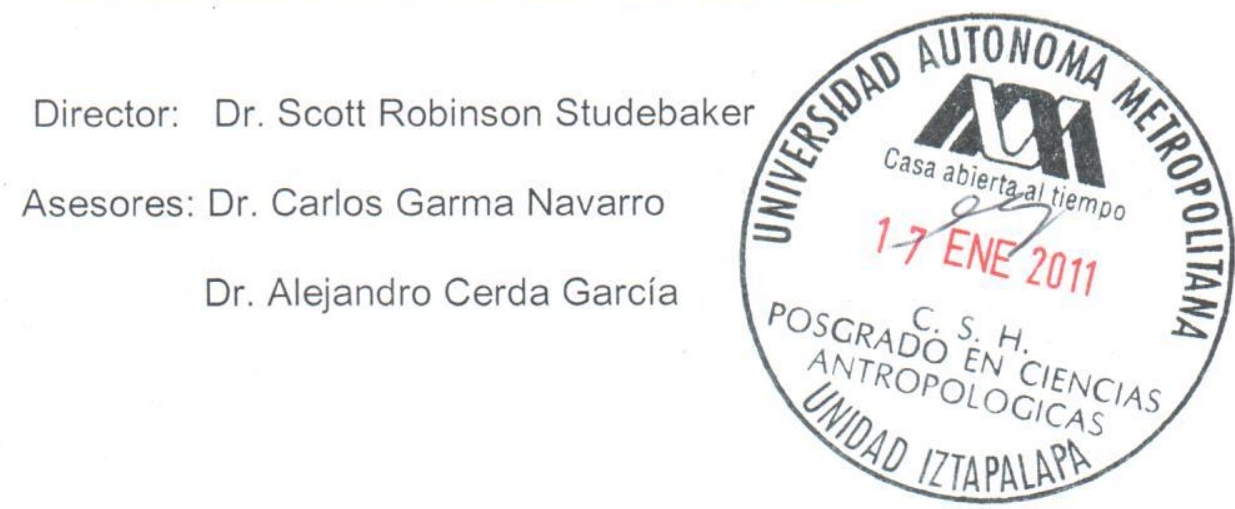

México, D.F.

Agosto, 2009 